ANDRÉ YUITI OZAWA

\title{
CESÁRIO VERDE: GUARDADOR DO EFÊMERO
}

UNIVERSIDADE DE SÃO PAULO - USP

São Paulo - SP

2017 


\section{CESÁRIO VERDE: O GUARDADOR DO EFÊMERO}

Tese apresentada ao Programa de Doutorado em Literatura Portuguesa da Faculdade de Filosofia, Letras e Ciências Humanas da Universidade de São Paulo, como requisito parcial à obtenção do título de Doutor em Letras.

Área de concentração: Literatura Portuguesa.

Orientadora: Profa. Dra. Maria Helena Nery Garcez Universidade de São Paulo

Faculdade de Filosofia, Letras e Ciências Humanas

Departamento de Letras Clássicas e Vernáculas UNIVERSIDADE DE SÃO PAULO - USP

São Paulo - SP 
Autorizo a reprodução e divulgação total ou parcial deste trabalho, por qualquer meio convencional ou eletrônico, para fins de estudo e pesquisa, desde que citada a fonte.

Catalogação na Publicação

Serviço de Biblioteca e Documentação

Faculdade de Filosofia, Letras e Ciências Humanas da Universidade de São Paulo

OZAWA, ANDRÉ YUITI OZAWA

099C CESÁRIO VERDE:GUARDADOR DO EFÊMERO / ANDRÉ YUITI OZAWA OZAWA ; orientadora MARIA HELENA NERY GARCEZ GARCEZ. - São Paulo, 2017. $146 \mathrm{f}$.

Tese (Doutorado) - Faculdade de Filosofia, Letras e Ciências Humanas da Universidade de São Paulo. Departamento de Letras Clássicas e Vernáculas. Área de concentração: Literatura Portuguesa.

1. LITERATURA PORTUGUESA. 2. POESIA. 3. HERMENEUTICA. I. GARCEZ, MARIA HELENA NERY GARCEZ, orient. II. Título. 

NOME: OZAWA, André Yuiti.

TÍTULO: Cesário Verde: Guardador do efêmero.

Tese apresentada ao Programa de Doutorado em Literatura Portuguesa da Faculdade de Filosofia, Letras e Ciências Humanas da Universidade de São Paulo, para obtenção do título de Doutor em Letras.

Aprovado em: $/ 2017$

\section{Banca examinadora}

Prof. Dr. Instituição:

Julgamento: Assinatura:

Prof. Dr. Instituição:

Julgamento: Assinatura:

Prof. Dr. Instituição:

Julgamento: Assinatura:

Prof. Dr. Instituição:

Julgamento: Assinatura:

Prof. Dr. Instituição:

Julgamento: Assinatura: 
À professora, orientadora e amiga, Maria Helena Nery Garcez, que teve paciência de Jó e amizade da santa homônima, para conduzir-me até aqui.

À minha família, pelo amor incondicional, com ou sem doutorado, com ou sem mestrado, apenas porque eu sou eu.

À minha esposa, Aline Bento Ozawa, luz dos meus olhos, sangue do meu coração, ânimo do meu espírito.

Gratias tibi, Deus, gratias tibi. 


\section{AGRADECIMENTOS}

Aos amigos e diretores do Centro de Estudos do Pacaembu, pelas constantes orações e pela ajuda na formação pessoal necessária para a realização deste trabalho.

Ao professor Álvaro Cardoso Gomes, que anos atrás deu-me não somente uma oportunidade, mas um rumo profissional e acadêmico.

Ao Roberto Ueda, pelo processo de formação pessoal a que tem se dado o trabalho, como se algo de valor pudesse daqui sair.

A Evandro Faustino, Guilherme Freire e Regina Shintani, pelas discussões que, mesmo que não diretamente ligadas a este trabalho, ajudaram ao esclarecer questões humanas.

Aos professores Raquel Sousa e Eduíno Oríone que, na qualificação deste trabalho, contribuíram de forma decisiva para a realização dele.

Aos professores Emerson Cruz, Horácio Costa, Annie Gisele e Mônica Simas que, por todo o percurso acadêmico, mostraram-se sempre generosos e profundamente comprometidos com a literatura e a universidade. 


\section{RESUMO}

A presente tese discute a efemeridade como aspecto constitutivo e motivador na obra de Cesário Verde, e como a apreensão da fugacidade, é um gesto de amor e de vontade de preservação dele. Utilizando a estética pareysoniana, as leituras a partir de tal hermenêutica querem revelar como a formatividade da obra mostra tal mundividência.

Palavras-chave: Literatura Portuguesa, Hermenêutica, Efemeridade, Poesia do século XIX. 


\section{SUMMARY}

This thesis discusses ephemerality as a constitutive and motivating aspect in Cesário Verde's work, and as the apprehension of fugacity, it is a gesture of love and a desire to preserve it. Using Pareysonian aesthetics, the readings from such hermeneutics want to reveal how the formativity of the work shows such a worldview.

Keywords: Portuguese Literature, Hermeneutics, Ephemerality, Poetry of the 19th century. 


\section{Sumário}

INTRODUÇÃO

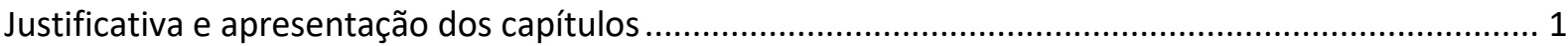

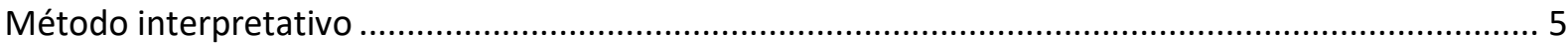

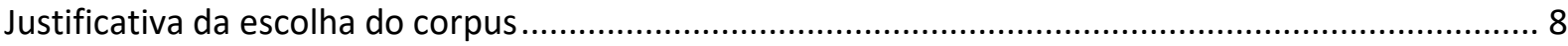

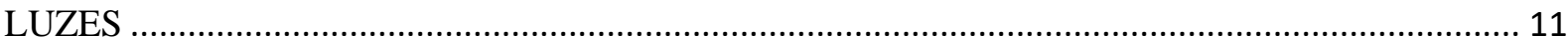

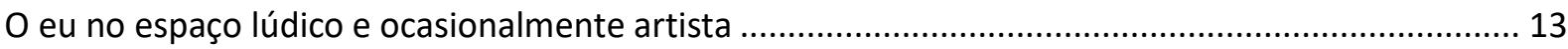

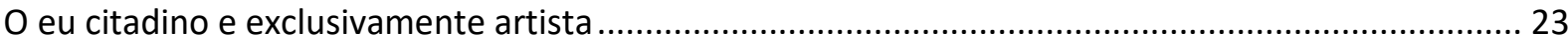

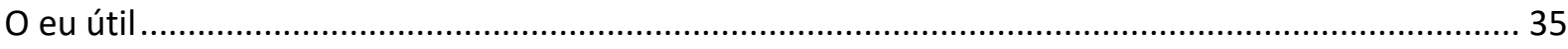

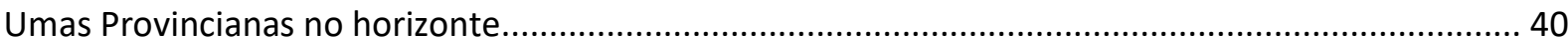

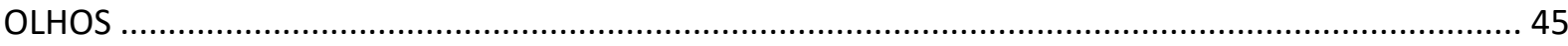

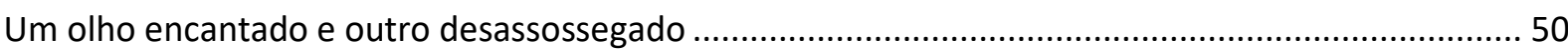

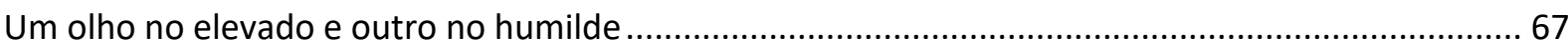

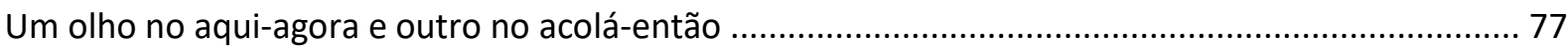

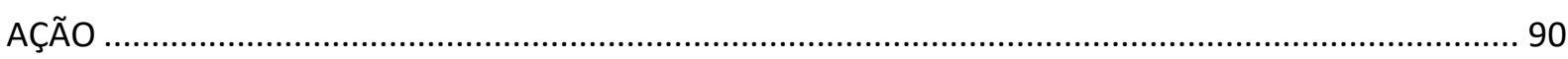

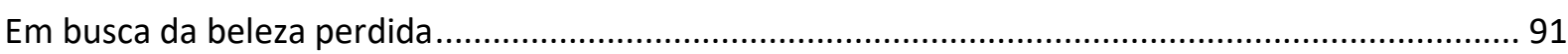

Retratos íntimos ou a arte como antídoto ao efêmero ................................................................ 107

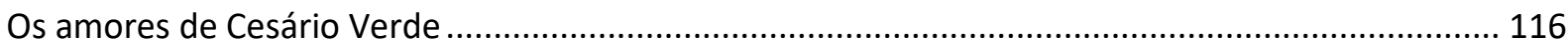

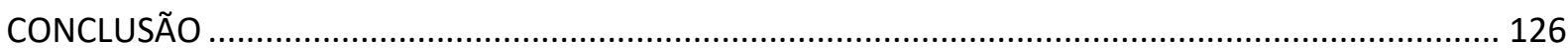

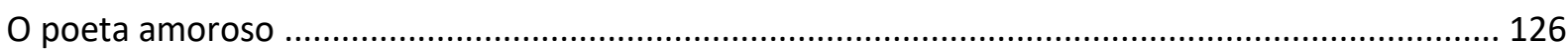

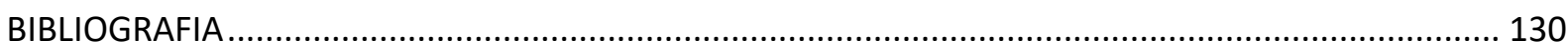

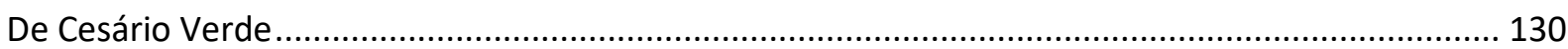

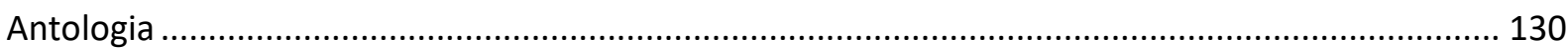

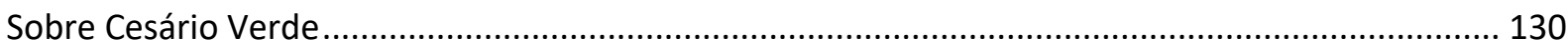

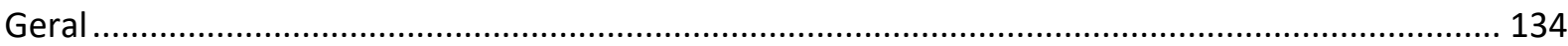




\section{INTRODUÇÃO}

\section{Justificativa e apresentação dos capítulos}

A ideia central da presente tese surgiu após a leitura de uma obra aparentemente sem conexão direta com a área literária, intitulada “O império do efêmero: a moda e seu destino nas sociedades modernas" do pensador contemporâneo Gilles Lipovetsky. Duas questões centrais neste livro levaram-me de volta a alguns versos de Cesário Verde, numa perspectiva que até então não se tinha-me revelado: a partir da moda (especificamente do vestuário), o livro apresenta uma perspectiva sócio histórica que discute a noção de identidade moderna tendo a roupa e seus adereços como a materialidade tanto de valores de determinada sociedade quanto de um exercício de individualidade. Como se sabe, a moda, principalmente no vestiário e, em segundo plano, em objetos menos óbvios(bairros inteiros, louças de almoço, gostos musicais etc.) é um aspecto da obra cesárea, mas foi em outro apontamento do referido livro que o spunto ${ }^{1}$ pareysoniano se revelou latente: a coerção social que a moda - em seu aspecto ideológico-, específica e impõe, paradoxalmente exige que o indivíduo se mostre (ou se individualize) no detalhe; é nessa atenção ao elemento "menor", ao efêmero (primeira definição dentro da obra do filósofo francês), que o ato de olhar e observar encontra um instante de fuga; e nesta fuga, uma pequena possibilidade de individualização.

A partir dessas duas ideias inicias, a moda e o refinamento do olhar, passamos a análise de alguns poemas, verificando a perspectiva de um e de outro. Para isso, além de tais ideias, também foi essencial a aproximação com o método interpretativo da hermenêutica refletida, proposta e aplicada pelo filósofo italiano Luigi Pareyson (1918-1991), principalmente em sua obra "Problemas da Estética". O embasamento interpretativo a partir de tais reflexões começou a dar corpo para o que era em seu início uma "intuição" (que chamamos, corrigindo tal conceito, aqui corretamente de spunto): percebemos que a ação de observar era, de fato, o verbo operatório principal da poética de Cesário. No entanto, isso o comprova anteriormente diversos outros críticos, de formas diversas, mas com a observação do fenômeno em comum.

\footnotetext{
${ }^{1} \mathrm{O}$ termo spunto será mantido no original italiano, não somente devido à dificuldade de encontrar uma tradução adequada, mas principalmente por se tratar de termo com características específicas e de originalidade teórica, proposta pelo pensador italiano sobre o ato formativo. Dessa forma, a partir de agora, ao utilizarmos o termo, abrimos mão do adjetivo autoral.
} 
Porém, graças ao método já explicitado, pudemos perceber que ao gesto várias e várias vezes mostrada do olhar, outro fenômeno, tão ou mais importante, era perceptível: o que se olhava eram elementos efêmeros. Da moda, em questão, começamos a visualizar esse elemento usualmente retratado nos poemas do poeta lisboeta. Imediatamente, além de tal ideia, lembramo-nos de diversas críticas que mostravam o aspecto artístico presente dentro dos poemas de Cesário, principalmente aproximando-o da arte plástica e da estética impressionista. Algo nos pareceu evidente a partir de tais ilações: tal intertextualidade não era à toa e revelava também um elemento da mundividência do artista, segundo lição aprendida de Pareyson. Para nós, era o aspecto desse tipo de pintura, que pretende congelar principalmente o instante, o passageiro, um indício essencial para a interpretação dos poemas estudados.

O efêmero, é, nesta dialética, a maneira da construção da identidade do sujeito. Em outras palavras, o adorno, este detalhe pequeno, seria a prova e o exercício (único) da individualidade. Ao mesmo tempo, o olhar se concentraria exatamente neste elemento: é o que Lipovestsky chama de "refinamento do olho". No entanto, a observação aguçada e atenta (modo de observação para que se chegue a tal refinamento), ao mesmo tempo que potencializaria e despertaria a sensibilidade estética, levaria à automatização do gosto, pela impregnação constante dos valores sociais apreendidos no ato observativo e contemplativo. Interessa-nos, principalmente, o conceito do refinamento do olhar. É possível especular que o sujeito que observa o elemento "menor", aprende a refinar-se por tal observação, tem sua sensibilidade desperta e atenta, humanizar-se-ia pela sensibilidade estética. Sem deter-nos no conceito de humanização ou humanidade, não parece ferir qualquer inteligência afirmar que a sensibilidade estética é um potencial inerentemente humano. Também o é a busca pela individualidade, isto é, reconhecer em si e nos outros traços distintos. É o ato de observar que o levaria a individualizar, pela possibilidade de também se distinguir dos outros e da própria sociedade em que está inserido. Perceber, no entanto, não efetivaria o ser. Observar e reconhecer toda uma sociedade e seus valores, exercitar a observação para conseguir se focar em elementos mais sociais, ainda não faria o indivíduo, sujeito. A esse aspecto iniciaremos a discussão adiante.

À tal noção de efêmero, outra ainda se revelou: a passagem do gosto, isto é, do tempo. Na observação da moda, o sujeito é, tal qual um espectador, colocado defronte ao teatro dos gostos e valores em sucessivas mudanças. Nessa peça, a mudança do gosto é também a materialização da mudança do tempo. Mesmo que a percepção de tão importante mudança não 
seja imediata, ela, ao ser percebida, mostraria outra característica do efêmero: a transitividade do tempo e, em última instância, do efeito dela sobre as coisas todas. Não é a finitude das coisas, a distância de um passado idílico em contraposição a um presente distópico, ou um presente idílico em que o tempo, “(...) esse cancro enorme”, rói lentamente, elementos essenciais na mundividência cesárea, e por consequência, em sua poética? Não seria pela percepção aguçada da temporalidade - e uma espécie de busca pelo antídoto contra o relógio, - o ato de estetizar tudo, inclusive os mínimos detalhes? Esse ato estético, além de "congelar" o tempo, também não seria uma tentativa da permanência da beleza inerente - mas também aparente - do mundo? Nessa perspectiva, a arte não seria somente a mímesis da realidade, mas a gestação de uma outra realidade, desvendada pelo olhar do artista e instaurada pelo seu gesto criador. A diferença é que a segunda "realidade" foge das leis do Tempo. É também esse aspecto do efêmero que levantaremos neste trabalho.

Por fim, a presença da moda também permite fazer a diferenciação de classes sociais obviamente também de valores. A presença da moda não é um detalhe descritivo - ou não é somente - mas antes a própria forma que o poeta encontra para situar o leitor em espaços, ideias, tempos, e constituir indivíduos. É também tal olhar para a moda, para o externo e para o outro, uma forma, por dicotomia de olhar para além dela, para dentro de si e para se constituir não somente como personalidade e indivíduo, mas ontologicamente. Ao se caracterizar como poeta em muitos dos seus poemas, ou ampliar-se como um poeta para além das palavras, ao estetizar o mundo ao seu redor e também o seu mundo interior, o eu-lírico constrói-se ao assumir a identidade de artista e o que tal escolha significa em um mundo onde a arte parece preocuparse mais em assumir posições políticas ou ideológicas, do que revelar a beleza das coisas. Não que uma coisa ou outra se exclua, ou que não haja beleza nos poemas "sociais" de um Antero de Quental, ou na prosa "realista” de um Eça de Queirós, seus conterrâneos e contemporâneos. Diríamos ser uma opção de ordem: sem a beleza, não há ser humano, sem ser humano, não há mundo. Essas são as opções temáticas, mas também de valores na obra de Cesário. Também discutiremos que isso é uma questão de grau: o menor, o despercebido, o comum, o cotidiano, o efêmero, ganham destaque em relação aos seus primos superlativos. Por fim, são suas escolhas por olhar e observar e então modalizar e estetizar, que constituem os verbos operatórios e identitários, que se traduzem pela sua poética e pela sua mundividência.

Assim sendo, a divisão deste trabalho se dá nas seguintes partes, a partir de três elementos que serão focados em instantes distintos, sem, ressaltamos, perder de vista que 
constituem um todo coerente, que é a própria obra do poeta. A parte primeira, intitulada "Luzes", discutirá a constituição do sujeito poético, centralidade de preocupação da obra. Na segunda parte, "Olhos", discutiremos como o ato de observar é dinâmico e constitui a forma que o poeta encontrou para fazer perceber a efemeridade das coisas, sempre olhando com uma espécie de duplo olhar. Nesse duplo olhar, constitui-se também a principal dinâmica poética aqui estudada: as várias dicotomias materializando-se e materializando esse conflito entre o ideal e o real, o passado e o presente, o idílio e a velocidade. A terceira parte, nomeada "Ação" se concentrará principalmente em notar a busca pela beleza, a arte que pretende preservar a beleza da passagem do tempo e os amores que promovem tal arte. A última parte intitula-se "O poeta amoroso" e é quando realizamos a síntese das premissas discutidas nas partes anteriores. Nessa síntese, pretendemos mostrar que a preservação do efêmero é principalmente um gesto de amor: amor tanto à beleza das coisas, quanto as coisas em si.

É patente que fizemos duas paródias, ou seja, dialogamos com duas ideias mais ou menos fáceis de serem reconhecidas: ao dividir as partes, utilizamos a expressão "luzes, câmera, ação", subtraindo a segunda palavra por outra menos anacrônica. A intenção é mostrar tanto a articulação entre as partes para um todo coeso, quanto a ideia do espetáculo (resultado das três palavras) como preocupação, logo constituinte de sua visão de mundo, do poeta. Espetáculo, tanto naquilo que se mostra, de forma mais "brilhante" e "embelezada", quanto especulação das coisas. Speculum, raiz de espetáculo, também é de especulação. O olhar para fora é também o olhar para dentro. O mostrar o fora é também mostrar o dentro. No segundo caso de paródia, aproveitamos a obra do heterônimo de Fernando Pessoa, o mestre Alberto Caeiro, assim como de um título interno à obra (O pastor amoroso), pela clara admiração que o poeta desassossegado nutriu pelo seu par menos famoso. Ainda que não façamos nenhuma comparação mais aprofundada entre um e outro, a "solução" da heteronímia para sentir tudo de todas as formas e também poder especular sobre as coisas de diversas perspectivas, principalmente compreendendo, segundo as próprias palavras do poeta, que uma forma de ver o mundo deve se construir com estilo próprio, - nos deu luzes sobre alguns elementos da poesia de Cesário e sua “obsessão" pela construção de um artista dentro de sua própria arte. Mas é o amor pelas coisas naturais, expressas em outro tom, que mais os aproxima e também mais subsídios oferece para a compreensão da vontade de estetizar o mundo. Foi-nos, dessa forma, irresistível ler os poemas aqui apontados também a partir dos olhos de Pessoa, mesmo que sem traçar viés comparativo e limitando-se a apontar algumas soluções estéticas deste para maior reflexão daquele. Pensamos que a escolha do foco no efêmero, e um viés comparativo em 
Caeiro seriam por demais extensas e possivelmente fora de nossas possibilidades interpretativas.

\section{Método interpretativo}

A metodologia adotada para a interpretação baseia-se principalmente nos estudos e reflexões do filósofo italiano Luigi Pareyson, concentrados na obra Problemas da Estética. Às diversas aplicações de suas teorias, contamos com inúmeros exemplos elucidativos de Maria Helena Nery Garces, sua tradutora para o Brasil e principal estudiosa. Entendemos que seriam eles parâmetros necessários, dada a complexidade que é a dialética proposta pelo pensador. Tal dialética se constitui a partir de dois conceitos, aparentemente opostos, mas que ele harmoniza mostrando-os interligados: a fisicidade e a espiritualidade de uma obra de arte. Mais que harmonizar, colocando-os lado a lado, consideramos a partir das reflexões do filósofo a íntima relação entre ambos os conceitos: tão íntima que a existência de um e de outro só se dão mutuamente, ao mesmo tempo. Em outras palavras, para começarmos a interpretação de uma obra poética (ou de qualquer obra de arte) partimos do princípio de que tudo nela que é material, físico, em suma apreensível pelos sentidos, também é a percepção do que nela há de espiritual, ou seja, as ideias e a visão de mundo que ela contém. Invertendo, temos o mesmo resultado: não há possibilidade da manifestação de ideias, mundividências, "inspirações" ou o que quer que nomeemos como a parte intangível da obra, que pudesse ser percebida sem sua construção física: é o princípio que Pareyson nomeia como o da coincidência de espiritualidade e fisicidade na obra de arte.

Na perspectiva paresynoniana, aqui também adotada, a arte é produção de objetos novos, que constituem "inovações ontológicas": entendemos que o aspecto que faz a obra ser obra é sua existência enquanto "ser", mas o que a qualifica, e também determina o seu ser, é seu aspecto de inovação. Essa qualidade se faz, pois, "ela não é execução de qualquer coisa já ideada, realização de um projeto" previamente concebido (PAREYSON, 2005, p.32), mas "um tal fazer que, enquanto faz, inventa o por fazer e o modo de fazer" (IDEM, ibidem).

Para melhor entendimento, lembremos que inventar vem do verbo latino invenire, que significa encontrar. Na atividade artística, portanto, o fazer e o inventar/encontrar são 
simultâneos. Mais: não se trata de um simples facere, mas de um perficere (per+facere), que significa fazer com inteireza, acabar, fazer com perfeição. (GARCEZ, [199?])

A esta estética, denominou-a formatividade, "que concebe as obras de arte como organismos vivendo de vida própria, dotados de legalidade interna e que propõe uma concepção dinâmica da beleza artística”. (PAREYSON, 2005, p.33). No entanto, o pensador faz notar que há uma intrínseca e inseparável dependência entre a forma e a visão de mundo do artista. A sua weltanschauung, implícita ou explicitamente, é introduzida na própria obra pela realização do aspecto "material" da obra, isto é, sua forma. Tal realização, revela o aspecto dinâmico da beleza artística e do próprio fazer artístico - através de sua "vida própria" (o próprio aspecto material da obra pronta lhe dá a autonomia em relação ao seu criador) -, que se concretiza enquanto arte(e concretiza) através da "legalidade interna"(sua própria "lei do belo" ou a sua coerência interna), A arte não consegue ser tal sem que nela confluam outros valores, pois lembra Pareyson retomando Dewey, a arte é sempre mais que arte; dela emana uma pluralidade de significados espirituais e nela se anuncia uma variedade de funções humanas. Os diversos valores contribuem para a realização do valor artístico, mas não se anulam nele; pelo contrário, alimentam-no e enriquecem-no.

Tornemos mais concreta esta explanação com um exemplo tirado da obra: Intencional ou não, a moda, tal qual Cesário Verde apreende em seus poemas, permite a percepção de detalhes de vestimentas, objetos, espaços e até comportamentos. Também torna possível compreender a mentalidade do eu do poema que apreende e descreve elementos mundanos e modais: às vezes, comportando-se como um narrador dentro do próprio poema, outras, numa diluição da poesia no gênero dramático (além do gênero narrativo já apontado), em que o diálogo faz o papel do "narrador" ou das reflexões do eu-lírico. É preciso destacar também a variedade de formas poéticas que adota, apesar da preferência ao decassílabo e, ocasionalmente o alexandrino. ${ }^{2}$ Ressalta-se, entretanto, que o que pretende o artista mostrar, torna-se sua

\footnotetext{
${ }^{2}$ Sobre o uso dos metros decassílabos e alexandrinos, David Mourão-Ferreira escreve um exemplar artigo, enumerando os poemas em que tais versos aparecem, confirmando o que Jacinto do Prado Coelho afirmara anteriormente: "A escolha corresponde ao teor descritivo, ao modo analítico da visão do circunstante, e também ao gosto do exato, a certo geometrismo de 'engenheiro' da poesia". MOURÃO-FERREIRA, David "Sobre o decassílabo e o alexandrino na poesia de Cesário Verde". In: Revista Colóquio/Letras. Ensaio, n. ${ }^{\circ}$ 93, Set. 1986, p. 74-81.
} 
maneira particular de fazer arte precisamente pela forma que mostra. Essa conceituação é essencial: a moda não é somente um algo apreendido, mas também a forma como se apreende e como se formatiza o apreendido; e que, ao final, é possível verificar a diluição de formas poéticas e estilísticas diversas presentes na obra de Cesário Verde, como próprios de sua mundividência e de sua poética. Nessa íntima relação entre o conteúdo e a forma da poesia, baseamo-nos especificamente nos seguintes trechos pareysonianos: “(...)tudo na obra, mesmo a mínima inflexão estilística, é significante, revela a espiritualidade do autor e, por isso, também o seu modo de pensar, a sua Weltanschaaung, a sua filosofia" (PAREYSON, 2001, p.49):

O corpo físico da obra de arte não é um instrumento mais ou menos necessário para comunicar uma imagem interior, e nem ao menos é o indispensável aspecto externo de uma realidade interna que, mais profunda e escondida, viva dentro dele e dentro dele se deva colher e penetrar, ou a necessária manifestação física de uma realidade superior ou ulterior que se patenteie através dele e para ele aluda além de si. Ele basta a si mesmo e constituí a totalidade da arte. " (PAREYSON, 2001, p.155)

O conceito de coincidência amplia a noção de leitura da obra arte. $O$ filósofo aponta um processo que começaria com a ideia de executá-la, isto é, "fazê-la ser" na sua própria realidade e na vida com a qual ela própria quer viver. Dessa forma, a obra "cria" a sua própria realidade, isto é, sua coerência interna (a verossimilhança aristotélica), ao mesmo tempo em que, ao ser interpretada por um intérprete, sujeito histórico, ela o conduz (e não este simplesmente a "revelaria"), pelos mesmos elementos materiais discutidos anteriormente, a dar-lhe vida, isto é, executá-la. No caso da análise de poesias, lê-la; ou, sendo mais próximo de um conceito chave do método pareysoniano, aproximar-me, enquanto pessoa, de uma forma e ter sempre em mente que ela apresenta uma infinidade de aspectos, de possibilidades, de nuances, cada um dos quais a contém por inteiro, embora nunca se possa exaurir a sua infinidade. A pessoa, por sua vez, pode adotar infinitos pontos de vista, isto é, infinitos modos de ver a obra, cada um dos quais contém toda sua espiritualidade, embora também não exaure todas as suas possibilidades. A interpretação, seria, para Paresyon, uma "congenialidade", a instauração de uma "simpatia". Interpretar consiste, portanto, em colocar-se próximo a um dos aspectos percebidos na obra: “(...) o sujeito procura ter seu objeto claramente diante de si, na sua inviolável independência para poder nele fixar a fundo o olhar e chega a uma identidade final, onde a obra entrega-se plenamente à imagem que soube revelá-la', afirma Garcez(199?). 
Entretanto, e isso será visível nesse trabalho, tal perspectiva torna clara, patente e lógica a impossibilidade de abarcar todos os aspectos de uma obra e explicá-la somente sob um único viés, sem considerar a dinamicidade da interpretação, somada aos aspectos próprios do intérprete e suas limitações. Nosso objetivo é que o aspecto, por fazer parte da obra, possa revêla por inteiro, isto é, mostrar-se coerente em si e com a obra, ao destacar determinadas questões; entendemos, no entanto, que tal revelação não é única, já que a obra é dinâmica e a interpretação, dependente de distintas "genialidades", ainda que perceba as regras internas e a formatividade autoral.

Uma determinada interpretação, que parte de um ponto de vista, colhe um aspecto da obra (que apresenta infinitos aspectos) e, se cada um deles contém a obra toda, estando, por isso, em condições de revelá-la por inteiro, todavia, nenhum deles pode pretender monopolizála. Dessa forma, quando interpretamos uma obra literária apresentamos nosso encontro com aquela forma, olhada sob um de seus infinitos aspectos. Se esse aspecto foi capaz de revelá-la por inteiro, sabemos também que ele não a esgota, que não é um ponto de vista necessário nem exclusivo. A obra de arte é inexaurivel e é por isso que o processo interpretativo é infinito. A interpretação, enquanto revelação da obra é objetiva, mas enquanto expressão do intérprete é, ao mesmo tempo, pessoal. No entanto, pelo fato de as interpretações poderem ser muitas $e$ pessoais não se deve concluir que sejam arbitrárias e indiferentes. O processo interpretativo não está abandonado à subjetividade, mas obedece a uma lei firmíssima, que é a própria obra e a um critério seguro, a congenialidade, que é a condição de penetração na obra. Discernir o valor artístico da obra, julgá-la, diz-nos Pareyson, nada mais é do que comparar a obra tal qual é com a obra tal qual ela própria queria ser. (Garcez, 199?)

\section{Justificativa da escolha do corpus}

A obra poética de Cesário Verde tem hoje uma rica crítica: tanto em abordagens quanto em quantidade. Notadamente, Joel Serrão, Helder Macedo, Janet Carter e toda uma miríade de críticos de porte como construíram e continuam a construir possibilidades de interpretação da obra poética de maneira consistente. Assim, a opção de uma nova leitura mostra-se sempre entremeada de outros discursos, em tom maior ou menor, dependendo do enfoque teórico que se selecione. As "simpatias" e as "congenialidades" entre tais críticos e a obra de Cesário também se refletem nesta obra. $O$ presente trabalho não poderá ignorar a procedência da leitura 
sociológica de Macedo, a apreensão do sujeito em Carter, a relação histórica feita por Serrão, ou as diversas contribuições, em livros ou artigos, destacando um ou outro aspecto, principalmente das questões estilísticas da obra do poeta novecentista. À cada "mundividência" de cada crítico, impõem uma seleção distinta de corpus, mas, em regra, como ensina Pareyson, a interpretação pressupõe uma simpatia. A nossa, materializa-se também, além dos aspectos interpretativos que nos deteremos, na escolha dos poemas. Como se poderá notar, os critérios adotados foram os seguintes: a) presença de referência à arte dentro do próprio poema; b) poemas em que a questão da passagem do tempo se dê explicitamente; c) poemas em que os aspectos efêmeros, que detalhamos anteriormente, contribuam para a percepção, principalmente, das reflexões (essas também implícitas) do sujeito sobre tal fenômeno. Poderíamos definir a própria impossibilidade da fixação de valores, ou seja, a efemeridade, como um dos aspectos mais importantes que a obra poética do autor sugestiona, através principalmente da dicotomia. Não há assunto mais abordado ao se lidar com a obra do poeta lisboeta: desde a canônica leitura campo-cidade, iniciada por Hernani Cidade e interpretada sob diversas perspectivas, notadamente a de Helder Macedo(2001), de concepção sociocultural que reconstrói os pólos dicotômicos; de Alfredo Margarido(1983) que amplia para a questão da representação cromática; da representação intertextual com outras formas artísticas em Helena Carvalhão Buescu (1983 e 1986), até recentes trabalhos que abordam aspectos como as classes sociais ou os tipos humanos que aparecem na obra (notadamente Janet Carter, 1988).

Como a interpretação será em close reading, alguns poemas serão utilizados somente como argumentos de referência, isto é, apontaremos que determinado elemento artístico também pode ser visto em outro momento da obra, sem os analisar completamente, entendendo, no entanto, que ao apontar como o efêmero nelas surge, estamos também desvelando algum aspecto de tais poemas; outros, serão analisados à exaustão, já que, para nossa compreensão, são basilares para apreendermos mais amplamente as formas artísticas e o mundo que o poeta aqui estudado legou ao mundo. Os livros utilizados para cotejarmos os poemas foram três, com preferência para o primeiro, por se tratar de trabalho de estabelecimento dos textos reconhecidamente bem realizado e sem grandes conflitos críticos, e mais amplamente utilizado; entretanto, consideramos essencial ter em mente que a obra publicada por Silva Pinto, ainda que contenha elementos distintos aos poemas publicados em jornais ou revistas, também é, em sua medida, uma interpretação da obra de Cesário, em suas divisões, realizadas por alguém que conviveu intimamente com o poeta - não parece sensato descartar algumas opções de edição. 
Por último, o estudo realizado na edição de Carlos Felipe Moisés, dividindo a obra por ciclos cronológicos e aproximando-os através de elementos semânticos também serviram de reflexão para a escolha dos poemas, bem como algumas soluções interpretativas. Os títulos das obras são: Obra Completa de Cesário Verde, com estudos e organização de Joel Serrão; O livro do Cesário Verde, publicada por Silva Pinto; e Cesário Verde: Poesia Completa e Cartas Escolhidas, edição preparada por Carlos Felipe Moisés.

Talvez seja desnecessário lembrar que não há uma edição crítica, e provavelmente nunca haverá, das obras aqui estudadas. Com esse comentário, já nos escusamos considerando possíveis interpretações baseadas em opções distintas de estabelecimento dos poemas, que são os que se seguem(entre parênteses, o nome com que o poema aparece na edição de Silva Pinto): Impossível, Cantos da Tristeza (Setentrional), Caprichos (Responso), Esplêndida, Arrojos, Vaidosa, Flores Venenosas, Melodias Vulgares (Flores Velhas), Cadências tristes, Deslumbramentos, Humorismos do amor(Frígida), Ironias do Desgosto, Desastre, Contrariedades(Nevroses), A débil (Na cidade), Humilhações, Num Bairro Moderno, Merina, Sardenta, Cristalizações, Noitada, Num Álbum, Em Petiz, Manhãs Brumosas, O Sentimento dum Ocidental, De tarde, De Verão, Nós, Provincianas. 


\section{LUZES}

Agonizava o Sol gostosa e lentamente, Um sino que tangia, austero e com vagar,

Vestia de tristeza esta paixão veemente, Esta doença, enfim, que a morte há de curar.

(Flores Velhas, Cesário Verde)

Ao conjunto de poemas escolhidos para estas análises, seguindo o critério já apontado na introdução deste trabalho, procedeu-se, inicialmente, a verificação de recorrências lexicais e semânticas. Dessa forma, coerentemente com o método interpretativo utilizado, teríamos uma visão, primeiramente, de conjunto, e poderíamos passar, posteriormente, para uma análise específica e contextualizada que pretendesse perceber algumas questões poéticas e, assim, juntamente com essa, a mundividência do artista ou uma parte de tal mundividência. Como é a poesia, sucintamente definindo, arte que se vale do potencial da "palavra" em toda a sua materialidade e em sua potencialidade imagética e referencial, perceber a recorrência de escolhas e usos de determinados léxicos, parece ser um lógico início do processo interpretativo. Compreendemos a importância da escolha do léxico para a representação do mundo, de si, e da memória, e que, dentro de um sistema poético tão estruturalmente - métrica e sonoramente "arquitetado", somado a apresentação de tais palavras, em regra, por um artista dentro do poema, a análise deve se deter com mais minúncias, percebendo onde as "luzes", isto é, aquilo que o poeta pretende mostrar e construir, recaem.

Ao submeter o corpus escolhido ao programa WordSmith Tools ${ }^{3}$, pudemos constatar a recorrência de certos léxicos, a qual, no primeiro momento, apresentamos por aproximação semântica ou gramatical: algumas palavras gramaticais sem conteúdo semântico imediato, como algumas conjunções e interjeições chamaram a atenção pela quantidade de ocorrências, o que exigiu uma reflexão generalizada que precedeu a contextualizada. Diferente

3 O programa WordSmith Tools é um conjunto de programas integrados destinado à análise linguística, desenvolvido por Mike Scott e comercializado pela Oxford University Press, estando em sua sétima versão atualmente. O programa é empregado em pesquisas lexicográficas realizadas pela editora que o comercializa e em análises diversas desenvolvidas por linguistas, professores e estudantes de línguas em escala mundial. 
procedimento foi adotado com os pronomes demonstrativos, por compreender a necessidade da leitura contextualizada, antes de se emitir qualquer juízo interpretativo relativo a eles. A mesma lógica de considerar somente no contexto do poema poderia ter sido aplicada aos pronomes pessoais ou possessivos - e teria - não fossem eles tão abundantes, o que, de imediato, exigiu uma maior atenção e algumas considerações sobre se o seu uso e a sua relativa recorrência são características comuns a poesia lírica e/ou elementos constitutivos da poética estudada. Por fim, concentramo-nos mais longamente nos substantivos mais abundantes, já que, surpreendentemente, o número de adjetivos repetidos era ínfimo em amostragem, o que por si, também gerou outra especulação. Um advérbio em especial (“sempre” - 17 repetições) também exigiu um olhar mais especulativo, e rendeu algumas considerações que reforçam as percepções iniciais. Assim, por número de repetições, a lista de palavras obtida com a ferramenta, do maior para o menor número(ou até onde se tornou relevante) é a seguinte: Eu - 191 ocorrências, Não - 102 ocorrências, Como - 158, Teu - 47, Tu - 40, Quando - 43, Tudo - 39, Meu - 38, Nós 38, Seu - 36, Seus - 34, Teus - 23, Sem - 59, Minha - 35, Ela - 33, Sol - 27, Vida - 22, Mar - 21, Nem - 21, Noite - 21, Olhos - 21, Sua - 19, Amor - 18, Tua - 18, Ah -17, Bem - 17, Luz - 17, Sei -17, Sempre - 17, Ser - 17, Só - 17, Ter - 17, Mulher - 16, Nunca - 16, Pobre 16, Quem - 16, Dois - 15 .

O pronome pessoal do caso reto "eu" apresentar o maior número de ocorrências pouco poderia dizer em uma olhada apressada, já que se trataria de considerar tal uso abundante simples decorrência do gênero poético predominantemente adotado por Cesário, o lírico; além disso, mesmo poemas de características narrativas, como "Num Bairro Moderno" ou "O sentimento de um Ocidental", apresentam um narrador autodiegético. O uso do "eu" nessa perspectiva, seria mero lógica constitutiva da linguagem e das características do texto escrito e suas exigências coesivas, além de um ou outro caso de necessidade rítmica ou métrica. Porém, considere-se que mesmo sendo a recolha das recorrências lexicais dentro do corpus escolhido, este é extenso e representativo o suficiente, quer numericamente, quer pela "qualidade" dos poemas, para poder se afirmar que há uma recorrente definição do "eu” dentro da obra. Recordese que o recorte proposto na obra se dá em torno de três condições: eu poemático que se se descreve ou se mostra um artista, elementos ligados à moda, e elementos que consideramos marcas de efemeridade, ainda manteve a grande maioria dos poemas conhecidos de Cesário; a bem da verdade, dos 40 poemas conhecidos, publicados e anotados por Joel Serrão, somente 8 não atenderam a tal critério de seleção, não sendo incorporados ao corpus deste trabalho. Parece-nos que tais números dão permissão para as especulações que se seguem. 


\section{O eu no espaço lúdico e ocasionalmente artista}

À medida que se lê a obra de Cesário Verde, percebe-se que a definição do eu lírico como um artista se dá por processo de auto definição ou por inferência: no primeiro caso, o sujeito do poema declaradamente se nomeia um artista (quer das Letras, quer utilizando outra arte poética), como nos casos abaixo.

E daria, contente e voluntário,

A minha independência e o meu porvir,

Para ser, eu poeta solitário,

Para ser, ó princesa sem sorrir,

Teu pobre trintanário.

(Esplêndida)

A adulação repugna aos sentimentos finos;

Eu raramente falo aos nossos literatos,

E apuro-me em lançar originais e exatos

Os meus alexandrinos...

(Contrariedades)

E eu, que urdia estes fáceis esbocetos,

Julguei ver, com a vista de poeta,

Uma pombinha tímida e quieta

Num bando ameaçador de corvos pretos.

(A Débil)

Os casos em que, por inferência, percebe-se o eu do poema como um artista ou como alguém com talentos ou pretensões artísticas são muito mais numerosos:

Talvez já te esquecesses dos poemetos,

Revoltos como os bailes do Cassino,

E daqueles byrônicos sonetos

Que eu gravei no teu peito alabastrino. 


\section{(Setentrional)}

Mas fina de feições, o queixo hostil, distinto,

Furtiva a tiritar em suas peles,

Espanta-me a atrizita que hoje pinto,

Neste dezembro enérgico, sucinto,

E nestes sítios suburbanos, reles!

(Cristalizações)

E eu que busco a moderna e fina arte,

Sobre a umbrosa calçada sepulcral,

Tive a rude intenção de violentar-te

Imbecilmente, como um animal!

(Noite Fechada)

Lembrei-me muito, muito, ó símbolo das santas,

Do tempo em que eu soltava as notas inspiradas,

E sob aquele céu e sobre aquelas plantas

Bebemos o elixir das tardes perfumadas.

(Flores Velhas)

Eu buscava uma rima bem intensa

Para findar uns versos com amor;

Olhaste-me com cega indiferença

Através do lorgnon provocador.

(Loura)

Subitamente - que visão de artista! -

Se eu transformasse os simples vegetais,

A luz do Sol, o intenso colorista

Num ser humano que se mova e exista

Cheio de belas proporções carnais?!

(Num Bairro Moderno)

Criança encantadora! Eu mal esboço o quadro

Da lírica excursão, de intimidade. 
Não pinto a velha ermida com seu adro;

Sei só desenho de compasso e esquadro,

Respiro indústria, paz, salubridade.

(De Verão)

E eu que medito um livro que exacerbe,

Quisera que o real e a análise mo dessem;

Casas de confecções e modas resplandecem;

Pelas vitrines olha um ratoneiro imberbe.

Longas descidas! Não poder pintar

Com versos magistrais, salubres e sinceros,

A esguia difusão dos vossos reverberos,

E a vossa palidez romântica e lunar!

(O Sentimento de um Ocidental)

Pinto quadros por letras, por sinais,

Tão luminosos como os do Levante,

Nas horas em que a calma é mais queimante,

Na quadra em que o Verão aperta mais.

Tínhamos nós voltado à capital maldita,

Eu vinha de polir isto tranquilamente,

Quando nos sucedeu uma cruel desdita,

Pois um de nós caiu, de súbito, doente.

(Nós)

Percebe-se, pelos casos, que há uma vontade contínua do eu do poema em se auto definir como um artista, tanto mais aludindo aos seus dons artísticos ou ao fazer artístico. Essa quase obsessão nos parece fruto do valor à arte e do fazer artístico que Cesário demonstra, nos poemas, e em várias ocasiões de sua vida, mas, principalmente, a necessidade de construir para si uma identidade e um valor - a primeira, como poeta "profissional", e a segunda, o reconhecimento de sua arte. Como veremos, nem uma, nem outro, em vida ou mesmo imediatamente após a sua morte (salva as exceções já conhecidas, entre elas Silva Pinto), lhes são concedidos pela crítica ou por seus pares. 
É famosa a correspondência comercial em que, aborrecido por um erro contábil, além da provável falta de cuidado com a escrita do interlocutor, o escritor demonstrar, por suas próprias palavras, "ser um homem de letras antes de ser comerciante" (VERDE, 2003, p. 250):

No que, porém, V.S. ${ }^{\text {e }}$ erra sozinho e com toda a certeza é em formar uma opinião leviana e precipitada do meu modo de proceder e em dar lições e repreensões que eu rejeito, tendo o meu cérebro e a minha consciência que me dirigem perfeitamente bem. Acabo de receber uma carta sua cheia de faltas de sintaxe, de ortografia e de educação e respondo imediatamente. Acho espantosa a sua pretensão de que eu não estou à altura de compreender os seus negócios. Ora eu tenho dado superiores provas intelectuais em muitos ramos da arte, da filosofia e da ciência e seria curiosíssimo se eu, que entendi as estâncias de Lord Byron, não entendesse uma estância de madeiras. (...). Por último advirto-o de que sou um homem de letras antes de ser negociante e que o meu gosto literário é muito exigente. Nem todos os autores me agradam. Rogo-lhe por isso que me poupe à leitura das suas insuportáveis lucubrações mercantis. ${ }^{4}$

No que se refere à recepção desfavorável de sua obra, ela terá, em um primeiro momento, um razoável impacto em alguns momentos da obra do poeta, e de forma esperada, altera o uso do eu poemático. Pensemos no caso de Esplêndida, e a recepção publicada na Farpa $n^{o} 22^{5}$ de Ramalho Ortigão:

“(...). Averígua-se que o realismo baudelairiano está fazendo mais numerosas e mais lamentáveis vítimas do que o velho romantismo de Byron, de Lamartine e de Musset. (...). Tal é a deplorável influência (...) na poesia moderna representada na obra de um dos seus cultores, o snr. Cesário Verde, ao qual

\footnotetext{
${ }^{4}$ A carta, dirigida a Augusto Francisco Vieira, faz parte do conjunto conhecido e sobrevivente ao tempo e alguns acidentes, colhidas em FIGUEIREDO, João Pinto. Álbum de Cesário Verde, com Fotografias e Cartas Inéditas do Poeta" e consta da edição de Joel Serrão, utilizada neste trabalho.

${ }^{5}$ As Farpas foram publicações mensais feitas por Ramalho Ortigão e Eça de Queirós, no mesmo ano da realização das Conferências do Casino: aparecem em 1871, assinadas por Ramalho Ortigão e Eça de Queirós até o ano seguinte, e somente pelo primeiro até o fim, 1882.
} 
sinceramente desejamos que estas modestas observações contribuam para que continue a ilustrar o seu nome, tornando-se cada vez menos Verde e mais Cesário."

A crítica de Ortigão deste poema faz eco com outra: Cesário diz ter ouvido de um amigo, em carta a Silva Pinto, que o escritor Teófilo Braga haveria censurado a maneira como o sujeito do homem desce à posição de lacaio para angariar as simpatias de uma mulher e acrescenta que "um poeta amante e moderno devia ser trabalhador, forte e digno e não devia se rebaixar assim". A crítica, desfavorável ou inexistente causaram, como é de se esperar, um certo afastamento do poeta do fazer artístico somado a isso, a necessidade de envolver-se mais e mais nos negócios da família. É de se pensar que tal formação e responsabilidades vão aparecendo mais explicitamente após a má ou nula recepções às suas poesias: é interessante perceber que o eu poeta vai sendo cada vez menos invocado - chegando em algumas situações de se ausentar completamente, principalmente nas poesias que se assemelham a quadros impressionistas ou as que apresenta o universo campesino (notadamente Nós e Provincianas - esta, sem o eu-lírico, restrito ao nós coletivo).

Além da questão biográfica, que transparece em seus poemas, também podemos aventar, sem risco de excesso, que a constituição do eu começa em um processo de emulação de influências românticas e vai se desenrolando em um processo cada vez mais complexo e pessoal. Ainda assim, quando o sujeito poemático passa a ser definido como artista, permite a compreensão de alguns elementos: as condições em que ele faz a sua arte, seus objetos de inspiração e o resultado de sua arte. A nós, interessa particularmente perceber que a constituição do eu enquanto artista, e posteriormente, abrindo mão de assim se definir, vai mostrando um ocultamento ou um processo de coletivação, principalmente em situações de contato com pessoas humildes. Não é possível dizer que essa intenção é explícita ou é um desenrolar de uma percepção sobre si mais apurada ou real, mas ela aparece de forma intermitente, num crescente, até o poema Nós - ou, como preferimos pensar, no que seria o poema Provincianas. No entanto, aventamos também a hipótese da morte, a partir de certa parte de sua vida, rondando o seu lar e ele próprio, como elementos transformadores de sua estética. Isso ficará, no entanto, como discussão final. Por ora, vejamos como se dão as construções de um eu em destaque para um em que o coletivo se sobrepõe. Impomos um trajeto que se visualizou cronológico, entendendo, no entanto, que as obras primeiras também já mostram alguns elementos da mundividência do artista, que vai, assim como o homem, modificando-se. Embora exista, não nos impomos o 
risco de falar em evolução, mas em aprimoramento, ou cunhando um termo menos usual, vivência, compreendendo, juntamente com Pareyson, que o formar a matéria artística é também uma técnica, além de das condições únicas do sujeito que a produz: dessa forma, como técnica, vai se tornando mais "ousada" ou reconhecendo as possibilidades de expressão de sua espiritualidade. Essa, também, é importante lembrar, no que já tem algo de primordial, vai se desvelando e ampliando o potencial pela dialética do sujeito e seus conflitos. Não se afirma, no entanto, que as obras mais hodiernas do artista sejam mais representantivas de sua mundividência ou de sua arte, mas uma parte que compõe um todo coerente. É essa parte que nos concentraremos a seguir:

No poema Cantos da Tristeza ${ }^{6}$, publicado em fevereiro de 1874, apesar da polêmica da edição e do título (ver nota de rodapé), temos alguns elementos marcantes que se tornarão recorrentes na poesia do autor, mas para ordenamento e estruturação deste trabalho, o foco estará, por ora, como dito, em mostrar o eu e sua constituição. Neste poema, o eu é explicitado 7 vezes, e o pronome comigo, em duas ocasiões. A aparição do primeiro eu, no entanto, acontece após vários casos do uso de primeira pessoa do plural. Vejamos:

Talvez já te não lembres, triste Helena,

Dos passeios que dávamos sozinhos,

À tardinha, naquela terra amena,

No tempo da colheita dos bons vinhos.

Talvez já te não lembres, pesarosa,

Da casinha caiada em que moramos,

Nem do adro da ermida silenciosa,

${ }^{6}$ N'O Livro de Cesário Verde, edição de Silva Pinto, o poema recebe o nome de Setentrional e tem mais de 9 quadras suprimidas. No entanto, esclarece Joel Serrão que essa poesia foi publicada como a utilizamos, isto é, com as quadras suprimidas, com o artista ainda vivo. A mudança do nome parece atender a uma visão critica do editor que transfere o foco do poema do ato (o canto) para uma característica física da mulher retratada, pela alusão à parte mais ao norte do globo terreste ou seus habitantes. É interessante que tenha modificado também outro título de poema publicado para Meridional, o antônimo do poema aqui lido, mantendo a corência. O problema, nos aprece, é que, enquanto os títulos modificados mostram um olhar para o "céu", as escolhas de Cesário, em regra, são para "baixo", em elementos mais comuns, como flores, ou as mudanças temporais. 
Onde nós tantas vezes conversamos.

Talvez já te esquecesses, ó bonina,

Que viveste no campo só comigo,

Que te osculei a boca purpurina,

E que fui o teu sol e o teu abrigo.

Que fugiste comigo da Babel,

Mulher como não há nem na Circássia,

Que bebemos, nós dois, do mesmo fel,

E regamos com prantos uma acácia.

Talvez já te não lembres com desgosto

Daquelas brancas noites de mistério,

Em que a Lua sorria no teu rosto

E nas lajes campais do cemitério.

Talvez já se apagassem as miragens

Do tempo em que eu vivia nos teus seios,

Quando as aves cantando entre as ramagens

O teu nome diziam nos gorjeios.

A primeira quadra apresenta a interlocutora, a "triste Helena", e também já nos dá a visão da relação temporal e pessoal entre o sujeito e ela: afastamentos, entre o homem e a mulher, do espaço que será apresentado como paradisíaco, a "terra amena", e por consequência, o “(...)tempo da colheita dos bons vinhos" também no passado. Não é, apesar da referência, no entanto, o Éden, ou são o sujeito e Helena, os primeiros pais. Assim, a colheita dos bons vinhos, ao contrário da que acontece na Bíblia, depende do sujeito e não de Deus. Aliás, é essa a grande ironia e provavelmente, os cantos, no plural da tristeza: mais dele, aparentemente, do que dela, no claustro.

Neste espaço, sobra ao homem a saúde e a mulher, a beleza, há plena participação com a natureza, e perebe-se a plena realização do amor entre ambos. Quadra após quadra, o idílio amoroso e o locus amoenus são descritos lentamente, detalhadamente. O sujeito, ainda que somente se definirá como artista mais adiante, mostra-se, primeiramente e principalmente, um trabalhador e um provedor: daí a colheita, a casinha caiada, e colocar-se como 
osculatório $^{7}$ ("Que te osculei a boca purpurina"), o sol e o abrigo. Cesário utiliza-se de tantas referências religiosas colocando-se como substituto de Deus, que sequer aparece nomeado no poema, condizente com sua visão "prática" e "positivista" do mundo, em suas próprias palavras em várias cartas ${ }^{8}$. Assim, ao se hiperbolizar, ou se colocar como única necessidade e único criador no poema, pode-se perceber a incompreensão da atitude da mulher amada. Também se percebe porque o uso repetido da mesma estrutura frásica "talvez", no início de tantas quadras: ela reitera o estado "presente" do eu-lírico, metido em elucubrações e indefinições. Outro uso é reiterado é a conjunção "quando", que, nos dá tanto a notação temporal, quanto, em alguns casos, a condição. Esses recursos vão criando uma musicalidade - os tais cantos - além de reforçar o tempo, o espaço e as condições em que ambos, principalmente o sujeito, estavam em estado encantado. A natureza toda mostra-se gentil, poética e amena. O desencantamento se dará, exatamente, a partir da descrição do eu como um artista, mas também novamente partícipe da "velha cidade tão sombria':

Talvez já te esquecesses dos poemetos,

Revoltos como os bailes do Cassino,

E daqueles byrônicos sonetos

Que eu gravei no teu peito alabastrino.

De tudo certamente te esqueceste,

Porque tudo no mundo morre e muda,

E agora és triste e só como um cipreste,

E como a campa jazes fria e muda.

Esqueceste-te, sim, meu sonho querido,

Que o nosso belo e lúcido passado

Foi um único abraço comprimido,

Foi um beijo, por meses, prolongado.

E foste sepultar-te, ó serafim,

${ }^{7} \mathrm{O}$ osculatório é, nas antigas cerimônias apostólicas, pequena placa com a representação de uma imagem sacra que devia ser beijada pelos fiéis antes da comunhão.

${ }^{8}$ Sobre a ausência da transcendência, discutiremos na conclusão. 
No claustro das Fiéis emparedadas,

Escondeste o teu rosto de marfim

No véu negro das freiras resignadas.

E eu passo tão calado como a Morte

Nesta velha cidade tão sombria,

Chorando aflitamente a minha sorte

E prelibando o cálix da agonia,

E, tristíssima Helena, com verdade,

Se pudera na terra achar suplícios,

Eu também me faria gordo frade

E cobriria a carne de cilícios.

A partir dessa quadra, em que o homem forte, que podia carregar a mulher como se nada pesasse, mostrado como um provedor e um protetor inigualável, mostra a sua outra faceta: o artista refinado, conhecedor das mais nobres técnicas poéticas e, tal qual Deus grava em pedra os Mandamentos, ele, o trabalhador/artista, também o faz no peito da amada. E, alterando o ritmo mais pausado das estruturas frásicas anteriores, com as palavras "talvez" e "quando" impondo um ritmo de leitura mais lento do que as três últimas quadras, iniciadas pela conjunção “e”, mas também com maior profusão de aliterações com a mesma sonoridade, que altera o ritmo e a cadência, acelerando o poema, como se o canto triste estivesse atingindo o seu grand finale, num ritmo mais prosaico e lamurioso.

É importante notar que o artista desaparece nos quadros contemplativos da beleza da mulher e da natureza e ele, em regra, se portava, prazerosamente, como um "pajem", a servir a ambos - mulher e natureza - para que a perfeita harmonia não se desfaça e ela não tenha qualquer trabalho, mesmo que seja desprender os seus cabelos de alguma vegetação. Tudo que resta a ela é, com ele, desfrutar da beleza presente em cada ação (mesmo prosaica, como "os cânticos das rãs" ou "os meigos ditirambos/Que os rouxinóis teciam nas olaias"). Lá, a natureza é a verdadeira artista, e os cantos são, por dicotomia, "alegres" e o sujeito contenta-se em ser servidor e contemplativo. Cá, na cidade, os cantos tristes, são proferidos pelo sujeito que, ativo, faz poesia citadina "Revoltos como os bailes do Casino" ou recorre de fontes europeias, os "byronicos sonetos", e deambula, tristemente, nervosamente (perceba-se o ritmo), e do advérbio "talvez", passa-se para o "certamente", para o "Esqueceste sim", para o "aflitamente". A 
atividade do sujeito agora, parece ser somente a arte e o deambular. Da constituição heroica, positiva, segura, dá-se a transformação para o lamurioso, confuso e perdido. Lá, mesmo como co-realizador, já que tudo está dado, sente-se mais potente. Nesse reconhecer uma plenitude que a cidade, e por metonímia, as obras citadinas, não podem oferecer, há um sentido que será recuperado em alguns poemas ambientados no campo (mas não todos, pois a percepção de tais qualidades ou elementos naturais depende também do sujeito construído no poema - vide, por exemplo De Verão, que analisaremos sob outra perspectiva).

As referências religiosas, no tempo presente e no espaço citadino tornam-se negativas, em oposição ao natural Éden do campo e do passado. Mas, como percebe e vaticina o sujeito, "De tudo certamente te esqueceste/Porque tudo no mundo morre e muda". E é essa mudança, que o sujeito faz questão de colocar como algo frio, ao rimar com o adjetivo "muda", nos versos "E como a campa jazes fria e muda". A de se perceber o uso proposital da palavra campa, laje ou pedra que cobre o túmulo ou um pequeno sino, que faz clara oposição ao campo. O feminino, aqui, é mostrado como negativo, no que discutiremos com mais precisão adiante. Cabe ressaltar que, apesar a primeira acepção, de laje de túmulo ser a mais óbvia, o uso para a sineta cria um sentido coerente com a oposição aos sons agradáveis, naturais e vivos encontrados na terra amena, já que se trataria de um objeto feito pelo homem, e possível de ser utilizado na missa, conhecido como carrilhão (antes de alguns passos litúrgicos) ou antes e após refeições em espaços mais formais, notadamente, por exemplo, o claustro. O som produzido agora, é frio e mudo, pois não invoca mais a vida natural, segundo o sujeito.

Neste poema, mais do que em qualquer um, percebe-se a imagem que o sujeito faz de si em relação também a religião: obra humana, terrena, ela, a religião, não poderia levar o homem a sua plena realização. No caso da mulher, ela está sepultada sob as paredes do claustro. No caso dele, não apresenta a vida. Como Cesário mostra isso, no entanto, é por construção retórica, isto é, propondo a tese (o homem era feliz na natureza, em harmonia com a mulher), a antítese (o homem é infeliz na cidade, pois separado da amada) e uma síntese (logo, a mudança é algo ruim) que se liga à impossibilidade de solução no tempo presente e no mundo terreno, além da incompreensão do destino da mulher amada: "Se pudera na terra achar suplícios/Eu também me faria gordo frade/E cobriria a carne de cilícios”. A terra (ou mais precisamente, o mundo), como notada, é paradisíaca. O sofrimento é construído pelo homem. No que não nega a Deus, nega à religião. Como o suplício para a dor libertadora do corpo e dos sentidos, típica atitude de mártires ou ascetas, é algo que não faz sentido ao eu do poema, pois é pelo corpo e pelos 
sentidos que absorve a felicidade e as sensações plenas, por que deles se livrar? E, se não há transcendência em seu olhar, mas um observar as coisas e dar por elas pelos seus acidentes não é possível entender a mudança como algo redentor de fato, e sim como consequência cronológica e material da finitude. É nessa consternação que termina o poema atual.

\section{O eu citadino e exclusivamente artista}

E em casos em que o ambiente é totalmente citadino, como o eu se constrói como artista e como ele vê a arte? E, principalmente, sendo exclusivamente artista, o que é mais importante, como ele se constrói? Para concentrarmos em um único caso, mas que serviria para "chave" parcial de outros, vejamos o poema Nevroses ${ }^{9}$

Eu hoje estou cruel, frenético, exigente;

Nem posso tolerar os livros mais bizarros.

Incrível! Já fumei três maços de cigarros

E agrado a pouca gente.

Dói-me a cabeça. Abafo uns desesperos mudos:

Tanta depravação nos usos, nos costumes!

Amo, insensatamente, os ácidos, os gumes

E os ângulos agudos.

Sentei-me à secretária. Ali defronte mora

Uma infeliz, sem peito, os dois pulmões doentes;

Sofre de faltas de ar, morreram-lhe os parentes

E engoma para fora.

Pobre esqueleto branco entre as nevadas roupas!

Tão lívida! O doutor deixou-a. Mortifica.

Lidando sempre! E deve a conta na botica!

\footnotetext{
9 Mesmo caso anterior, surge n'O Livro com substanciais mudanças, de supreções e no título, nomeado posteriormente como Contrariedades. Utilizamos a versão impressa em vida do artista, e mantemos o titulo, pois ele mostraria mais uma característica do sujeito, do que das consequências, entendendo, no entanto, que ambos mantém o espírito de conflito do poema.
} 
Mal ganha para sopas...

O obstáculo estimula, torna-nos perversos;

Agora sinto-me eu cheio de raivas frias,

Por causa dum jornal me rejeitar, há dias,

Um folhetim de versos.

Que mau humor! Rasguei uma epopéia morta

No fundo da gaveta. O que produz o estudo?

Mais duma redação, das que elogiam tudo,

Me tem fechado a porta.

É provável ser este o poema em que há maior descontentamento entre o eu poeta à recepção a sua obra, e reflexões sobre o valor da arte - tanto a dele, quanto da arte enquanto fazer humano em si, "realisticamente", em termos relativos e absolutos. Primeiramente cabe analisar as características do $e u$ neste poema, principalmente por podermos visualizar o já discutida pouca boa vontade da crítica com a obra do poeta, mas o quanto é a arte, acima de tudo, menor do que algumas questões vitais, como o próprio viver, ou mais surpreendente, como é o artista retratado neste poema, menor do que uma simples engomadeira. Daí os quadros que se contrastam: em primeiro plano, o do poeta insatisfeito e inútil, expendendo a sua energia com raiva, rasgando uma "epopeia morta" ou fumando; em um plano secundário, mas paralelo e dialético com o primeiro, a pobre passadeira. É neste contraste que a reflexão sobre a arte e a crítica artística aparecem explicitamente, enquanto o objeto que seu olhar vai encontrando beleza e valor - a passadeira - é colocada no poema, como se fosse algo incidental. Não é, como veremos: de fato, nos parece ser esta relação a que melhor define a mundividência de Cesário em relação a arte e que, posteriormente, tornará ainda mais explicita o que a arte significa, além de um alter ego ou uma satisfação pessoal. A arte é, principalmente quando é somente ela que pode desvelar aquilo que está oculto (a passadeira, os trabalhadores do campo, a verdureira), e somente quando ela pode preservar a memória, útil, pois em si, é gesto amoroso. Não é de surpreender que a definição do artística neste poema está ligado ao gesto amoroso, como se vê nos adjetivos ligados ao eu ou ao fazer artístico, mas especialmente, em dedicar tantos versos para acompanhar a tísica, como se ela desempenhasse um teatro ou uma dança vital e de uma beleza sem par (a despeito dela, em si, fugir dos padrões vigentes). 
Primeiro, o seu eu poeta é definido pelo ato de amar, de maneira insensata, “(...)os ácidos, os gumes/E os ângulos agudos”. Adiante, também vislumbramos (e vislumbramos pela declaração direta, como também pela própria constituição dos versos) o seu apuro (palavra e gesto tão cuidadoso e amoroso) em “(...) lançar originais e exatos/Os meus alexandrinos...”. Há, nestes dois trechos a declaração de uma poética fundamental na obra do poeta: o apuro, os cortes abruptos na sonoridade, mas também nos enquadramentos (pelos "gumes"), a temática mais corrosiva e a linguagem menos delicada (os "ácidos”) e as mudanças súbitas de olhar, de sequência descrita ou narrativa(os "ângulos agudos"), são todos elementos técnicos a serviço dos sentimentos. Além disso, também é de se questionar sobre o que ele escreve? Por que não tem melhor recepção crítica? Podemos tentar compreender pelo o que nos é apresentado neste poema e a partir do comentário direto sobre os motivos da péssima acolhida de sua poesia pelos literatos de então: “A crítica segundo método de Taine/Ignoram-na(...)”. O Método de Taine consistia em fazer história e compreender o homem à luz de três fatores determinantes: meio ambiente, raça e momento histórico. Estas teorias foram aplicadas ao movimento artístico realista. De forma sucintíssima, podemos dizer que tal método ignora a irrepetível vida humana e a unicidade inerente ao ser humano. E esses são os dois elementos mais caros a mundividência do autor. Fica patente neste mesmo poema, pois no que o sujeito tem de clichê e esquemático, quase paródico, do artista incompreendido, a passadeira tem de misteriosamente único e original. E não é, afinal, uma dança inusitada, entre o estudioso, profissional liberal - logo, independente - cosmopolita e poliglota, entretanto insatisfeito e descontente, com a pobre passadeira, sem atributos físicos, sem suporte familiar ou social, à beira da morte, e que, a despeito de tudo isso, encontra alegria no trabalho e na música? Seria possível descrevê-la, sem ser através da poesia? Daí que o método de Taine, que pensa em um sistema reducionista de história e de ser humano, ainda assim aplicado principalmente nos romances de tese realistas, teriam algum tipo de explicação mais óbvia, como algum desvio psicológico ou alguma satisfação não explícita por trás de tais gestos. Na poesia, o ato de descrever, tal como utilizado, transforma toda a imagem em uma filosofia própria, pois ela é principalmente uma reflexão do viver em si, como ato único e irrepetível. A reflexão, no entanto, não é dada nem pela fala do artista nem pelos sentimentos que por ela nutre, pois o que dela percebe o deixa consternado, como podemos ver pelas orações interrogativas e exclamativas: as primeiras, criando uma pausa adequada para que não se deixe de refletir sobre a vizinha e sua condição; enquanto as segundas, aumentando e revelando a indignação sobre esses estados. É importante notar que o sujeito aparece somente na primeira frase do primeiro verso desta quadra final, mostrando a mudança de espírito. Essa mudança faz com que possa se concentrar naquilo parece importar mais, do 
que seus papéis mal recebidos: o mundo e as pessoas simples, que com ele lidam, sem desanimar. O corte produzido diminuí o valor do escritor para jogar luzes sobre a vida real haveria maior amor do que esse? E, paradoxalmente, por construir a passadeira de maneira imprevista e, dentro de tal imprevisibilidade, captar a beleza de suas ações irrepetíveis - e segundo o método de Taine, ilógicas - o eu artista neste caso, cura-se de seus rompantes e de suas contrariedades (ou de suas neuroses) não por seu esforço ou mérito, ou não apenas, mas pelo efeito que a beleza humilde, em contraposição à grandiloquente (a "epopeia morta"), desperta no sujeito. Assim, o trecho em seguida, com o "populacho", que brinca com a água da chuva, reforça que a beleza é menos construção forçada e estruturada, e mais amor, isto é, sensações.

\section{Com raras exceções merece-me o epigrama ${ }^{10}$. \\ Deu meia-noite; e em paz pela calçada abaixo, \\ Soluça um sol-e-dó. Chuvisca. O populacho \\ Diverte-se na lama.}

E estou melhor; passou-me a cólera. E a vizinha?

A pobre engomadeira ir-se-á deitar sem ceia?

Vejo-lhe luz no quarto. Inda trabalha. E feia...

Que mundo! Coitadinha!

Considerando-se que a constituição do artista é problematizada pela sua concepção de arte, e principalmente, pelo tipo de beleza que ele procura, pode-se aventar dois polos apostos de eu enquanto artista: aquele polo que percebe a beleza nas coisas humildes, naturais (considerando-se a essência da coisa e a ação), e aquele que a procura obsessivamente em elementos mais evidentes e grandiosos. Dentre eles, a beleza citadina e artificial - encarnada na moda. A consequência dessa busca é diversa também, já que, ao contrário do apagamento em que se congrega com o coletivo, há um aniquilamento do sujeito, que se sujeita a servir a

\footnotetext{
${ }^{10}$ Entre os antigos gregos, qualquer inscrição, em prosa ou verso, colocada em monumentos, estátuas, moedas etc., dedicada à lembrança de um evento memorável, uma vida exemplar etc. Ironicamente, o que há de exemplar e memorável neste poema, e digno de epigrama, é algo imperceptível: as ações mais simples do ser humano comum - quer na luta pela sobrevivência, quer se divertindo.
} 
mulher como lacaio, ou ainda, mais exageradamente, sua vontade de transformar-se em objetos a serem utilizados ao bel-prazer da mulher admirada. Este caso parece concretizar-se em Caprichos, enquanto o primeiro, transparece em Esplêndida:

Num castelo deserto e solitário

Toda de preto, às horas silenciosas,

Envolve-se nas pregas dum sudário

E chora como as grandes criminosas.

Pudesse eu ser o lenço de Bruxelas

Em que ela esconde as lágrimas singelas.

(VERDE, Caprichos) $^{11}$

Ei-la! Como vai bela! Os esplendores

Do lúbrico Versailles do Rei-Sol

Aumenta-os com retoques sedutores.

E como o refulgir dum arrebol

Em sedas multicores.

Deita-se com langor no azul celeste

Do seu landau forrado de cetim;

E os seus negros corcéis que a espuma veste,

Sobem a trote a rua do Alecrim,

Velozes como a peste.

É fidalga e soberba. As incensadas

Dubarry, Montespan e Maintenon

Se a vissem ficariam ofuscadas

Tem a altivez magnética e o bom-tom

Das cortes depravadas.

É clara como os pós à marechala,

E as mãos, que o Jock Club embalsamou,

\footnotetext{
${ }^{11}$ Publicada como Responso, n'O Livro, o que capta a forma poética e ressalta o clima religioso-ascético da mulher, e ironicamente transforma a resposta do sujeito em uma constante ladainha de querer ser qualquer objeto para estar próximo a ela.
} 
Entre peles de tigres as regala;

De tigres que por ela apunhalou,

Um amante, em Bengala.

É ducalmente esplêndida! A carruagem

Vai agora subindo devagar;

Ela, no brilhantismo da equipagem,

Ela, de olhos cerrados, a cismar

Atrai como a voragem!

(VERDE, Esplêndida)

Diversamente do poema Nevroses, embora, ao menos na parte final na mesma clave de construção do eu artista de Cantos da Tristeza - aproximando-se de um artista de caneta europeia com tinta exagerada, e, ressalta-se, citadina, - os poemas agora estudados hiperbolizam de tal maneira a busca pela beleza da mulher que desumanizam o sujeito, retirando dele a característica do amor e substituindo pelo deslumbramento ou pela magnetização. É fato que em ambos os casos o exagero coaduna-se com a ideia de artistas submissos ao amor: em Caprichos a intertextualidade com a coita amorosa trovadoresca, "Uníssemos, nós dois, as nossas covas, /Ó doce castelã das minhas trovas! ”, enquanto na outra peça poética, o artista se porta como um doidivana com ares de amante de uma poética ultrarromântica. Mas, se o artista diminui-se em Nevroses em comparação com o amor que sente pela passadeira e somente aparece explicitamente no conflito com a perda amorosa em Cantos, o completo anulamento do ser nestes dois casos é a mais explícita ideia de que a busca pela pode ser também, além de elixir da vida, veneno para a morte. Veneno extremamente atraente, de materialidade, mas essencialmente afastado na beleza natural: é o que, por exemplo, permite momentos idílicos em Cantos ou Nevroses. Ao contrário destes, os dois agora analisados afastam o eu e a mulher da natureza; no caso de Esplêndida, ela é a nobre citadina e em Caprichos, a cortesão do amor impossível. A Helena antes do claustro ou a anônima passadeira, são manifestações de outra relação de beleza e de amor.

Sem o antídoto da beleza natural, o eu artista abre mão de existir, quer como sujeito com alguma função social reconhecida (o poeta), quer como homem, ao preferir servir como objetos à amada. No caso de Caprichos, a coisificação, a zoomorfização, a descaracterização são os recursos utilizados para a construção (ou a perda da) identidade do sujeito. 
IV

E os abutres e os corvos fazem giros

De roda das ameias e dos pegos,

E nas salas ressoam uns suspiros

Dolentes como as súplicas dos cegos.

Fosse eu aquelas aves de pilhagem

E cercara-lhe a fronte, em homenagem.

V

E ela vaga nas praias rumorosas,

Triste como as rainhas destronadas,

A contemplar as gôndolas airosas,

Que passam, o giorno iluminadas.

Pudesse eu ser o rude gondoleiro

E ali é que fizera o meu cruzeiro.

VI

De dia, entre os veludos e entre as sedas,

Murmurando palavras aflitivas,

Vagueia nas umbrosas alamedas

E acarinha, de leve, as sensitivas.

Fosse eu aquelas árvores frondosas,

E prendera-lhe as roupas vaporosas.

As estruturações das estrofes reforçam a imagem diminuída do sujeito em relação à mulher amada: para cada quarteto que se mostra o outro, há um dístico dialogado (submisso, mais acuradamente) - ou responsório - em que o sujeito ali se (des) constrói. A submissão se 
constrói pelos dêiticos "ela", "lhe" ou por algum tipo de coesão. A partir da dependência sintática e semântica alude-se que o sujeito somente existe enquanto sombra ou coro da mulher do poema. A estrutura frasal repete-se com a alternância entre os verbos que iniciam os versos "pudesse/fosse", criando uma sonoridade repetitiva e monótona. A separação das estrofes também se marca radicalmente pela numeração romana entre elas, impedindo uma maior fluência e ritmo de leitura e do desenvolvimento imagético ou conceitual. O tom monótono, dado pela estrutura repetitiva do responso, reforça a impressão de inanição, de falta de potência e mesmo vitalidade do sujeito. A sonoridade dada pela estrutura, aludindo ao responso religioso $^{12}$, cria a atmosfera medieval adequada aos quadros que se pretendem pintar. Assim, percebe-se que o eu lírico recria o ambiente da cantiga trovadoresca não por elogio, mas para alongar tal momento histórico até a desventura: o que se passa com ele, para além do plano da simbolização que os elementos medievais e toa a poética nela presente podem sugerir, é mais a construção - pelo reforço da memória poética - de uma constante impossibilidade da realização amorosa, tanto lá (medievo), quanto cá, momento do poema.

Ora, se pensarmos que a alusão a uma poética determinada também é a de um determinado tempo - e seus elementos ideológicos - não é de se estranhar que Esplêndida dialogue com o ultrarromantismo - não somente por ser este tributário de soluções poéticas da arte medieval, mas colocar sob perspectiva similar o homem encantado pela beleza de uma mulher que o ignora, causando-lhe sofrimento. No caso do poema com características medievais, o sofrimento resulta das relações hierárquicas sociais(de categoria) que constroem barreiras entre o trovador e a amada - além da barreira moral, invisível mas imperativa, que os separa amorosamente pelas opções distintas de destino: o dela, recolher-se ao claustro e sofrer - segundo a visão do poeta -, enquanto o dele é (des)construir-se em objeto que possa apaziguar tais sofrimentos femininos. Dois ponts são importantes para a compreensão do que se diz, segundo ORIONE(2012):

O primeiro deles tem a ver com a centralidade da voz masculina, pois é o homem quem declara o seu amor à mulher (objeto do discurso masculino). Dito de outro modo: na poesia amorosa, cujo modelo são os cantares pautados pelo amor cortês, o homem é o sujeito do amor, e a mulher é o objeto amado. Quem ama é o homem; a

${ }^{12}$ Conjunto de palavras pronunciadas ou cantadas nos ofícios da Igreja católica, alternadamente por uma ou mais vozes, de uma parte, e pelo coro, como representante da assistência, de outra parte. 
mulher é amada. O poema-cantiga de amor é a manifestação do amante masculino em relação à amada feminina. Mais que isso: na tradição literária pós-medieval, quem diz o amor é o homem, pois a mulher é o ouvinte dessa fala que lhe é dirigida, ainda que muitas vezes ela não passe de uma abstração. Isso porque o amor cortês é uma ficção poética que reproduz, em esquema erótico-sentimental, a relação de vassalagem existente entre o cavaleiro e o senhor feudal. Os termos dessa equação social hierárquica e imutável são transpostos para a poesia sob a forma de uma relação erótica, na qual a mulher é a Dama inacessível (substituto poético do senhor medieval) e o poeta/cantor é o vassalo que lhe dirige juramentos de amor, como o fiel vassalo faria ao Rei. Além dessas marcas, encontramos na retórica cortesã a impossibilidade radical de realização do amor que o súdito dirige à Dama, pois ela lhe é superior em tudo, seja no plano social, seja no moral. A mulher dos cantares de amor é inacessível, objeto de um desejo nunca realizado, e costuma não corresponder aos anseios e afetos do amante. Tampouco ocorre a posse sexual por ele tão almejada. Impossível de ser vivido na prática, esse amor alimenta-se da própria falta e de sua fatal impossibilidade. Detalhe: quanto mais impossível a realização amorosa, quanto mais distante, fria e cruel a mulher se mostra, mais aceso é o desejo do amante em dedicar-lhe sacrifícios. Dizer o amor, portanto, tornou-se, na poesia ocidental, dizer a dor do amor. Na verdade, não existe poema de amor, mas apenas poema de dor de amor. O discurso amoroso é sempre doloroso, e, como sabemos, tal feição foi mais reforçada na lírica portuguesa do que na provençal. Os cantares de amor acentuaram o tema da "coyta" amorosa, ou seja, da dor de amor, que transforma o poeta num "coitado".

Esplêndida apresenta mudividência e soluções aproximadas, no impedimento amoroso, na construção da mulher distante, na humilhação do sujeito, nas catarses sensíveis a partir do deslumbramento pela beleza física feminina. Assim, ao utilizar o recurso tão marcadamente da intertextualidade e da recorrência, o artista cria um quadro sinótico, para que também as diferenças se ressaltem: neste caso, é a ausência do ambiente de "sonho", assim também mais "simbólico" do poema com características mais antigas, para uma maior proximidade com um ambiente citadino, contemporâneo. Entretanto, mais determinante é que há um encruecimento das relações a tal grau, que o sujeito poético perde o seu grau de identidade estético: na transformação em objetos no poema à moda responsaria, o eu, ainda que se transmute ou se transforme para objetos, animais, elementos da natureza, mantém ainda neles um senso de beleza: 
De roda das ameias e dos pegos,

E nas salas ressoam uns suspiros

Dolentes como as súplicas dos cegos.

Fosse eu aquelas aves de pilhagem

E cercara-lhe a fronte, em homenagem.

No poema de estética mais moderna, a coita adquire outra categoria, pois deixa de ser uma convenção, no sentido da motivação, do gestual, do quase pudor, para algo muito mais profundo e desviado. O homem lá, abre mão de ser poeta para ser "trintanário" - ajudante do cocheiro que viajava na boleia e executava pequenos serviços, - abrindo mão de qualquer dignidade pública. Nesse ponto, as diferenças ficam ainda mais ressaltadas. Sem o pudor, sem as convenções sociais, sem a vaidade, o que pode se tornar o homem? Tanto o louco, quanto aquele que pode estar perto da mulher amada. Nesse sentido, abrir mão do amor em nome da própria identidade, de valores socialmente construídos, de convenções sociais, do que quer que se pense ou se aponte, seria um gesto doentio? Ou haveria algum paliativo, um intermediário para não simplesmente anunciarmos que "sim, é doença”, elencarmos grande parte estabelecida da crítica literária que concorda com isso (e de certa forma, com muitas razões tem tratado este poema e outra situações análogas $\left.{ }^{13}\right)$ ? É essa problemática que mostra-nos surpreendentemente coerente na constituição dos sujeitos poéticos em Cesário: não importa como, importa é estar próximo à mulher amada, fisicamente. Vejamos primeiro as três estrofes finais, antes de retomarmos tal polêmica:

E eu vou acompanhando-a, corcovado,

No trottoir; como um doido, em convulsões,

Febril, de colarinho amarrotado,

Desejando o lugar dos seus truões,

Sinistro e mal trajado.

E daria, contente e voluntário,

${ }^{13}$ É notável a leitura de Helder Macedo sobre o masoquismo em Cesário Verde, coerente com questões históricas, psicológicas e analíticas, sem cair no diagnóstico apressado. MACEDO, Helder. Nós: Uma leitura de Cesário Verde. $4^{\circ}$ Edição. Lisboa: Editora Editorial Presença, 1999. 


\section{A minha independência e o meu porvir, \\ Para ser, eu poeta solitário, \\ Para ser, ó princesa sem sorrir, \\ Teu pobre trintanário. \\ E aos almoços magníficos do Mata \\ Preferiria ir, fardado, aí, \\ Ostentando galões de velha prata, \\ E de costas voltadas para ti,}

Formosa aristocrata!

Nota-se que a construção do sujeito é expressamente de quem se quer ver "feio", maltrapilho e desarrazoado "E eu vou acompanhando-a, corcovado,/No trottoir; como um doido, em convulsões,/Febril, de colarinho amarrotado,/Desejando o lugar dos seus truões,/Sinistro e mal trajado." Sendo esse perder-se a maneira de estar próximo ao objeto amado, de fato o estado do sujeito é patologicamente alterado daquilo que seria a convenção: continuar à mesa do Mata ${ }^{14}$. No entanto, o exagero da autoconstrução - ou da própria destruição - não são declarações sobre o que de fato importa? Também porque o sujeito não vai se perder completamente, mas trocar de função: de poeta burguês, como se implica na cena construída nos restaurantes da Lisboa de fins de século XIX, em plena tertúlia cultural, para alguém que simplesmente queira servir à mulher amada, pois assim também a tem perto. Seria esse servir, como um mero empregado, o que mais causaria espanto? O que importa, é que o servir tornase não meramente verbo operatório ou substantivo que materialize a ponte entre os amados, mas constituição da visão de mundo do escritor. E nesse sentido, quer como gondoleiro, como apanhador de frutas, como lua, como árvore, como ponte, o gesto amoroso não é meramente intelectual, nem simplesmente estético, mas atual e atuante. No primeiro sentido, pois exige aproximação real entre os sujeitos, fisicamente; no segundo, tal aproximação deve ser percebida

${ }^{14}$ É crucial o que diz Leyla Perrone-Moisés(2000) citando Helder Macedo: “observou que, «na pacata Lisboa, subindo a rua do Alecrim, embora 'num landau forrado de cetim' puxado por 'negros corcéis velozes como a peste', a máxima depravação a que aquela insólita, e algo improvável, aparição do 'lúbrico Versailles do Rei-Sol' poderia aspirar seria um almoço no Mata, ao cimo da rua, um restaurante famoso pelo seu bacalhau guisado com pimentões». O crítico mostra ainda como o artificialismo deste e doutros poemas eróticos torna improcedentes, tanto a indignação moral de um Teófilo Braga, quanto as interpretações psicológicas e biográficas dessas "depravações" por críticos mais recentes." 
e querida, e não ocasional ou acidental. Assim, abrir mão de ser poeta vislumbrador, para ser homem fazedor, é sair do acidente para a essência: em outras palavras, o ser poeta é adjetivo, enquanto haveria um eu substantivamente essencial por detrás de tais características. Enquanto adjetivo, ele pode se constituir com características árcades, medievais, românticas, barrocas, clássicas etc, percorrendo temporalmente um mesmo espaço: o da relação ou da vontade de constituição de relação entre alguém que ama e alguém que é amado? Sem simplismos, não é essa também a essência lírica da temática amorosa? Ou a identidade que o poeta assim assume? Tais roupagens não devem distrair, e isso parece ainda mais claro na poética aqui estudada, daquilo que fundamenta o mundo e como o sujeito nele se constrói: para nós, o grande conflito não é mostrar duas funções - poeta e trabalhador - por exemplo, que poderiam coexistir em tempos e espaços distintos, mas mostrar que um somente existe de fato em relação ao outro, isto é, seria uma dupla natureza, sem conflitos. Sem compreendermos isso, a notação da identidade do eu é meramente categorial, dentro de características e operações poéticas mais ou menos esperadas dentro de gêneros ou estilísticas, e consequentemente, muito mais identidade sócio histórica do que construção ontológica. Consideramos, concordando com ABDO (2005) que o fazer poético é construção ontológica também:

Primeiramente, a especificação formativa não subentende o exercício isolado de uma formatividade vazia (até porque isto seria impossível, considerando-se que a pessoa se faz sempre inteiramente presente em todos os seus atos), mas, pelo contrário, requer, para a sua sustentação, toda a plenitude da vida espiritual de quem opera, toda a sua vontade expressiva e comunicativa, traduzidas em modo de formar. É assim, portanto, quer dizer, já como componente orgânico da obra de arte, que o mundo do artista se faz presente na obra. Esse conceito de modo de formar permite entender o caráter autoreferencial do discurso artístico, enquanto discurso originador, que se constitui não somente como discurso sobre, mas, primordialmente, como fundador de uma linguagem e, portanto, de um mundo próprio que com ele se origina. $\mathrm{O}$ discurso primeiro de uma obra de arte é, pois, aquele que ela faz dispondo suas

formas de um modo específico - e não simplesmente o conjunto de juízos que ela eventualmente pronuncia sobre determinado assunto. O seu legítimo conteúdo revelase, então, o seu próprio modo de formar, enquanto modo de ver a realidade e de atuar sobre ela. É desse prisma que Pareyson teoriza a questão da autonomia da arte e das suas relações com a realidade. A forma artística, assim entendida, é, pois, essencialmente, "matéria formada", sem que isto signifique que seja puro traçado físico: dizer que a forma é matéria formada significa dizer que ela é, de per si, um conteúdo, 
um "conteúdo expresso", para usar o termo de Pareyson. Longe de sinalizar um formalismo, isto quer dizer que, na forma artística, tudo está carregado de significação, até as inflexões estilísticas mais discretas, enfim, tudo é significado. Dizer, pois, que a forma é matéria formada é o mesmo que dizer Em suma, o que Pareyson está pretendendo ressaltar é, primeiramente, que a obra de arte é expressiva e comunicativa não meramente quando toma o homem e seu tempo como assunto ou tema de discurso, mas enquanto os concretiza em si como modo: modo de formar que singulariza a obra e define o seu modo de ser."

Assim, a formação do sujeito no poema é de natureza dupla, nos seguintes sentidos: enquanto diálogo com gêneros e estatutos poéticos pré-estabelecidos, com modos operatórios e estruturais reconhecidos, aludindo à respectiva mundividência, e uma constituição declarada, expressa e querida, dentro dos poemas. Por isso, é recorrente não somente o uso do eu artista, mas o fazer poético dentro do poema. Esse fazer, ou seja, um verbo de ação que pressupõe potência, força capacidade, resultado, intervenção, mantêm-se enquanto se altera o objeto (arte ou colher maças), sem alterar o sujeito a essência do sujeito, ainda que modifique os adjetivos. Isso implicaria, considerar, finalizando o raciocínio sobre as caraterísticas mal avaliadas do eu do poema Esplêndida, que os adjetivos e os advérbios que constroem uma imagem deturpada do sujeito, pode modificar-se se também se modificar o objeto. Como exercício e argumentação, alteremos o perder-se por acompanhar a beleza da mulher citadina, pelo trabalho no campo, como acontece em Nós.

\section{O eu útil}

Que de frugalidades nós criamos!

Que torrão espontâneo que nós somos!

Pela outonal maturação dos pomos,

Com a carga, no chão pousam os ramos.

E assim postas, nos barros e areais,

As macieiras vergadas fortemente,

Parecem, duma fauna surpreendente

Os pólipos enormes, diluviais. 


\section{Contudo, nós não temos na fazenda \\ Nem uma planta só de mero ornato! \\ Cada pé mostra-se útil, é sensato, \\ Por mais aromas que recenda!}

Finalmente, na fértil depressão,

Nada se vê que a nossa mão não regre:

A florescência dum matiz alegre

Mostra um sinal - a frutificação!

(VERDE, Nós)

Os termos de construção do eu neste poema expõe cesuras radicais com o artista citadino: o ambiente também é outro, campesino, solidário, natural, saudável. As relações existem comunitariamente, e não por postulados: todos, os trabalhadores, os animais, as plantas, tudo é conveniente e essencial. Essa visão paradisíaca é percebida por LOURENÇO (1991) como a descoberta da inocência. Para o crítico, Cesário instaura um olhar sobre o mundo que resgata a inocência escondida num ambiente desumano, em plena modernidade, que é, por excelência, o tempo da não-inocência. É esta inocência, segundo o autor, que o afasta radicalmente de um mero esteticismo ou de uma mera emulação de poéticas e, por consequência, de sujeitos poéticos como Esplêndida ou Responso. Concordamos com a ideia da inocência, ampliando-a das questões substâncias inerentes a ela, para a consideração também temporal-espacial, mais do que uma modalização: e para nós, é o tempo primeiro da poética de Cesário. Esse tempo primeiro, que chamamos de imersão, em algumas características: o sujeito se recolhe(ou se apaga) no ato comunitário, em meio a uma natureza em que há sentido para tudo, e mostra, poeticamente dizendo, que a sua arte é de experiência. Tudo isso, no entanto, será melhor tratado adiante. Por ora, vejamos a situação da construção do eu.

As três estrofes anteriores denotam aquilo que víamos apontando anteriormente e agora cabe dedicar algumas linhas reflexivas: vemos a diluição do eu na primeira pessoa do plural, expresso, sem o recurso do seu uso como sujeito elíptico. O ritmo, marcado por diversas cesuras e vírgulas, com suas rimas consoantes e femininas, criam uma sonoridade extremamente altiva, alegre e abertas, claramente reforçadas pelo uso de assonâncias em vogais abertas. Toda a alegria e toda a admiração não pode ser mostrada somente como logos mas também como sensação material. As oclusivas (“quem”, “criamos", “carga”, "torrão”, "pomos" etc) marcam 
o ritmo forte desse trabalhar: não há ausência de virilidade, de vitalidade e de alegria. Neste momento, em que tudo está em perfeita harmonia, o quadro que se mostra e se visualiza, o tempo presente é vivenciado em sua completude, e não uma memória: toda a sinestesia, das sensações táteis da terra, da carga, dos finos aromas, da visão que a tudo abarca (principalmente a visão). Neste momento, em que o $e u$ é útil e produtivo, ele está definitivamente integrado e elevado no nós. Sozinho, ele sofre. Frase pobre e curta, mas que resume e retoma um polo importante para a dialética aqui pensada: nos poemas estudados para a compreensão da construção do sujeito, nenhum nos dá a sensação que este possibilita. Mesmo compreendendo que a compleição feliz, a plena realização não será preservada ad infinitum, ao menos como o sujeito gostaria, em nenhum momento há uma comunhão entre ele, os homens e o mundo em que o sujeito não tenha que mostrar-se útil, produtivo ou generoso.

De La Taille (2004), ao se colocar sobre a generosidade, faz a comparação desse valor com a justiça, explicando que são virtudes que se distinguem e se complementam. A justiça está naquilo que se concede ao outro por direito, enquanto que a generosidade está no que se concede sem aguardar retribuição: esta é uma virtude por excelência altruísta, visto que o ato generoso favorece inteiramente quem é por ele contemplado e não quem age generosamente. A justiça, em contrapartida, exige uma reciprocidade, uma vez que as regras devem beneficiar a todos, inclusive àquele que teve um ato justo.

(...) É claro que, sendo a justiça uma tradução de uma preocupação com o outro, ela também pode figurar entre as virtudes altruístas. Porém, este fato não deve nos impedir de notar dois aspectos essenciais que separam justiça da generosidade. $\mathrm{O}$ primeiro é o fato da justiça poder ser objeto legítimo de reivindicação pessoal, no sentido de uma pessoa exigir ser tratada de forma justa. É evidente que, neste caso, não se trata de atitude altruísta, pois ninguém pode, com legitimidade, exigir ser tratado de forma generosa, somente desejá-lo. Em suma, a generosidade é sempre genuinamente altruísta, a justiça não. O segundo aspecto é o fato de a justiça sempre visar o bem comum, portanto, também o da pessoa que age de forma justa. (...) Em resumo, o auto interesse, ao lado do interesse pelo outro, está sempre presente na justiça, mas não no caso da generosidade, pois nela apenas o interesse pelo outro está em jogo.

De La Taille (2006) ainda traça duas diferenciações entre justiça e generosidade, relendo as colocações de Comte-Sponville (1995): explica que a generosidade pressupõe um sacrifício, o "dom de si”, enquanto a justiça não implica necessariamente abnegação. Ao cumprimento do 
que se deve e não do que se pode, há o respeito a um direito alheio, não existindo o "dom de si", mas sim o estrito cumprimento de normas ou convenções. A esse respeito, vale ler a asserção de Comte-Sponville sobre a generosidade, em correlação à justiça.

A generosidade é a virtude do dom. Não se trata mais de "atribuir a cada um o que é seu", como dizia Spinoza a respeito da justiça, mas de lhe oferecer o que não é seu, o que é de quem oferece e que lhe falta. Que também se possa assim satisfazer a justiça, certamente é possível (dar a alguém o que, sem ainda lhe pertencer, sem mesmo lhe caber segundo a lei, lhe é devido de uma maneira ou de outra: por exemplo, dar de comer a quem ter fome), mas isso não é necessário nem essencial à generosidade. Daí o sentimento que às vezes se pode ter de que a justiça é mais importante, mais urgente, mais necessária, e de que ao lado dela a generosidade seria como que um luxo ou um suplemento da alma. (COMTE-SPONVILLE, 1995)

Além dessa diferenciação proposta por Comte-Sponville, que explicita a questão de que a generosidade requer dar algo sem ser pelo cumprimento do dever, constituindo-se, como sublinhamos acima, em que(...) justiça e generosidade dizem respeito, ambas, a nossas relações com outrem (...); mas a generosidade é mais subjetiva, mais singular, mais afetiva, mais espontânea, ao passo que a justiça, mesmo quando aplicada, guarda em si algo mais objetivo, mais universal, mais intelectual ou mais refletido. A generosidade parece dever mais ao coração ou ao temperamento; a justiça, ao espírito ou à razão. (Comte-Sponville, 1995,). Essa diferenciação apontada por Comte-Sponville de que a generosidade tem mais a ver com os sentimentos e emoções, enquanto que a justiça é tida como um valor da ordem da razão.

Além dessas definições, que voltarão a ser repensadas, o eu generoso também se constituiria a partir de outra noção. A palavra vem do latim generosus que designa o homem ou animal que é de boa raça. Para Descartes, o generoso é antes de tudo aquele que é de raça nobre e, no sentido figurado ou moral, aquele que demonstra grandeza de alma. Se concordarmos que a generosidade é uma ação sem fins imediatos, além dela em si mesma, extremamente subjetiva e afetiva, não seria nela a esperança de algum sentido, pela problemáticas mostradas no verso abaixo? Note-se que "neste caos" aponta para as "doenças", aquelas que iniciam o poema afastando o povo da Lisboa em caos. Mas haveria nelas uma espécie de determinismo, já que elas matariam apenas os "bondosos/E-custa a crer-deixam 
viver os maus! ". Ou haveria uma fraqueza na bondade e na generosidade? O poeta aponta que o problema não é de ordem física somente, mas também genérica: gerações e gerações de "ricos", que não viveram a "sujeira" do trabalho honesto, da vida da lida da natureza, não teriam desenvolvido antídotos contra algumas doenças, nem a vitalidade para delas se curar. Por um lado, sendo bondoso e generoso, mostra-se a classe social do sujeito - a boa família de Descartes. Por outro, sem uso, a genética, a educação, a estirpe, perde qualquer valor. Metaforicamente, sem a pressão, o desgaste, a violência e a força, o diamante não se lapida e permanece pedra bruta.

\author{
Ai daqueles que nascem neste caos, \\ E, sendo fracos, sejam generosos! \\ As doenças assaltam os bondosos \\ E - custa a crer - deixam viver os maus! \\ (...) \\ Pobre da minha geração exangue \\ De ricos! Antes, como os abrutados, \\ Andar com uns sapatos ensebados, \\ E ter riqueza química no sangue!...
}

Essa forma de se enxergar, destoa com o que se vinha discutindo e se mostrando até então: há uma interrupção, principalmente após a morte da irmã, não somente narrativa, mas na própria constituição do poema: somos colocados em outro tempo presente, após a apóstrofe, ao tempo da escrita. Nesse tempo, como em outra estrofe a final também mostrará, a memória atuará como o elixir da perda querendo reinvocar "Biscates, hortas, batatais, latadas, /No país montanhoso, com relevo! ". No entanto, é a partir da descrição" das telas da memória retocadas", que ele pretende alcançar alguma leniência, não mais da sensação vivida. Agora, há como camadas separando o sujeito da vivência: a primeira, o descrever - isto é, utilizar-se de um signo verbal, para mostrar imagens não verbais, presentes na tela, mas essas também, "retocadas". Colocando cada ação em um tempo distinto, a experiência da coisa-em-si fica ainda mais distante. Daí que tal distanciamento da pulsão de vida, do presente vivido, das coisas como elas se mostram e são imediatamente, não soluciona tal crise: em suma, não traz a vida. Os olhos, seus instrumentos artísticos principais, estão cansados. Os olhos, como metonímia do próprio sujeito, são fechados para que a experiência presente abra espaço para outra distante, mas menos desalentadora. 
Fecho os olhos cansados, e descrevo

Das telas da memória retocadas,

Biscates, hortas, batatais, latadas,

No país montanhoso, com relevo!

Tais constatações farão com que o poema termine de maneira disfórica: aos versos finais, do retorno à Lisboa, após a perda da irmã, inclui-se a súbita perda do irmão, e mostrarão que pode(ou poderia) ser o estatuto, entendido como um conjunto de regras, não somente poéticas, mas também estéticas, e, então, da própria ontologia do sujeito, de que o que resta é o nada. Essa seria uma coerente declaração com a aquela última frase, no leito de morte, captada pelo irmão, antes do final suspiro. A partir de 1884, a tuberculose progrediu e o poeta viu-se obrigado a procurar os ares do campo, refugiando-se na sua quinta em Linda-a Pastora, depois em Caneças e, por fim, no Lumiar. É aí que, a 19 de Julho de 1886, pelas cinco horas da manhã, após proferir "Não quero nada, deixe-me dormir", morre, com apenas trinta e um anos.

De tal maneira que hoje, eu desgostoso e azedo

Com tanta crueldade e tantas injustiças,

Se ainda trabalho é como os presos no degredo,

Com planos de vingança e idéias insubmissas.

E agora, de tal modo a minha vida é dura,

Tenho momentos maus, tão tristes, tão perversos,

Que sinto só desdém pela literatura,

E até desprezo e esqueço os meus amados versos!

\section{Umas Provincianas no horizonte}

Daquilo que rascunhou-se dizer no início, sobre o ato interpretativo, aqui se ressaltará e se fará uma reflexão em torno da ideia de Pareyson sobre a questão já dita da congenialidade, que, obviamente, ajuda a traçar as linhas dessas reflexões. Vejamos o que diz DA SILVA URIBE (2015): 
O exercício de congenialidade e infinidade no processo interpretativo não é um exercício que exija que o intérprete se se prive da própria pessoalidade. O exercício interpretativo pode exigir do intérprete que ele suprima algumas atitudes pessoais que se interpõe à compreensão da obra. Mas, isto não significa de modo algum, que a personalidade do intérprete seja um obstáculo à compreensão. Nessa esfera, Pareyson chama a atenção, justo para à congenialidade, isto é, a compreensão. A compreensão pressupõe a congenialidade, enquanto a profundidade constitui o prêmio da descoberta, esta, dar-se como ato de sintonia. Nesse sentido, a revelação responde à afinidade e isso explica as dificuldades e os erros da interpretação, todavia quando a diferença produz situações não congeniais e incompatíveis e provoca antipatia e insensibilidade. No entanto, mesmo nesse sentido, não se trata de obstáculos, embora seja difícil de superálos, o intérprete os enfrenta e adota sempre novos pontos de vista, com o poder de sua livre iniciativa vai transformando e inovando a substância histórica de sua pessoa. $\mathrm{O}$ intérprete, leitor, executor ou crítico sempre se acha diante da tarefa de explorar a congenialidade de que já dispõe e escolher novos autores, aqueles dos quais uma afinidade eletiva e uma natural congenialidade prometem uma profundidade mais segura. (DA SILVA URIBE, 2015)

O ato de sintonia - similar ao ato interpretativo aqui até então desenhado, sempre houve - e haveria de - enfrentar a própria mudança realizada enquanto se interpretava. Se a obra de arte não é um algo dado e somente revelado pelo artista, como defende Pareyson, também não é a interpretação. Ainda que a pessoa que interprete tenha tendências, ideias, vontades e "verdades", elas somente aparecem no ato interpretativo quando motivadas, despertadas, dialogadas com a obra. Ou, ao menos, se pretender de fato aproximar-se da obra, empaticamente, neste gesto descrito por Pareyson, respeitando a ontologia da obra. É nesse sentido que a leitura de Provincianas surge no horizonte: como se pretendeu, nesta primeira parte, não esgotar, mas cercear a ideia da constituição do sujeito, ligado ao ato do fazer - quer arte, quer ações prosaicas, a consideração era se haveria dois blocos dicotômicos - como parecia natural no início, entre o eu artista e o eu "natural", considerando ser essa uma maneira recorrente na organização poética e na visão de mundo de Cesário, ou poderia ser Provincianas e outros exemplares similares(“De Verão, ”De tarde”), uma síntese?

De imediato, é impossível afirmar, somente pela obra que ela seria uma intencionalidade afirmativa e definitiva de algo, mesmo que conste como sendo os últimos versos escritos, segundo Silva Pinto. Mas vale pensarmos no conceito de síntese aqui proposto: menos um 
exercício declaradamente lógico, a síntese na arte pode se dar pelo "conseguir" soluções técnicas que expressem a espiritualidade de um sujeito. Nessa perspectiva, olhar a obra de um poeta é acompanhar também movimentos de idas e vindas de alguns aspectos, de permanências e apagamentos de outros, de transformações e retomadas, isto é, vida. Uma pessoa com mentalidade mais estrutural (por exemplo, Fernando Pessoa), trataria de construir também, com mais cuidado, uma obra com um quê de desenvolvimento lógico. Ou seja, mais filosófica. $\mathrm{O}$ poeta que aqui tratamos é o poeta das percepções principalmente, e, após, da estetização delas. Dessa forma, muito mais sensível, sua obra também será mais dinâmica, ao sabor dos momentos, das reflexões, das emoções. Tal dinamicidade poderia ser percebida, colocando ou não Provincianas como último poema. Considerando-a como última obra, dir-se-ia que ela atinge o ápice da generosidade e do apagamento do artista, em prol da obra (mesmo não finalizada), ao mesmo tempo que despertaria um sentido de alento - agora no intérprete. Se também estava em processo de escrita como tal, de alento ao escritor, é uma conjectura que deixa inalterada a obra, mas é coerente com o que se propôs dizer até aqui, que podemos resumir no seguinte quadro: a constituição do sujeito enquanto artista se dá, em primeira instância, como algo menor, se a arte servir somente como elemento estético ou como floreio embelezante. A perda do amor ou a noção de distanciamento da mulher amada, como em situações mostradas em poemas como Cantos da Tristeza ou Melodias Vulgares, coloca o artista nesta condição, mostrando que a arte é algo incidental e não essencial. Outra condição de artista menor, é quando a arte se pretende maior do que à realidade: neste caso, Nevroses é exemplar em mostrar que a percepção do tema artístico deve centrar-se nas coisas pequenas e inauditas, e delas, retirar a verdadeira poesia heroica. É como se mostra a passadeira, em seu balé do trabalho diário, belamente construída em contraste ao risível e nervoso autor. Análoga é a situação em Num Bairro Moderno, mas neste caso, como logo veremos, a aproximação se dá em processo de verdadeira comunhão entre artista e pessoas comuns.

Dessa forma, aquelas constituições identitárias do artista marcadamente perturbadoras presentes em Esplêndida ou Caprichos desaparecem completamente em Provinciana, pois não há sequer o uso do eu nesse poema. O artista está no quadro descrito do povo, do campo, da manhã e das ações saudáveis. Está, pois se percebe pela linguagem e como se mostra, o extremo cuidado em elevar tais situações. E ele mesmo está em algumas poucas frases, de timbre humilde, coloquial e espontânea, como no "Olá! Bons dias! (...)” que abre o poema. Não anúncio de si, do que vê, do que sente, do que pensa, de como se vê: somente o cumprimento que a todos estende uma simpática e refrescante lufada de vigor. Surpreende ser este poema, 
especificamente, também escrito em metro pouco utilizado por Cesário, a hexâmetro. O verso mais curto cria um ritmo ainda mais vigoroso, dado os enjambements, criando um tipo de sonoridade que explode em diversas ocasiões, como em "A terra!(..)" /”às vagas"(...)"(..)garço". Tais rompantes vão se desenrolando e repetindo, colocando cada imagem em seu devido espaço, e dando-lhe o devido apreço. Nada fica de fora, nestes versos "apetados", e nada fica sem destaque, pela cadência admitida. O que não aparece, pois está como o pintor a querer resgatar a experiência do que vê, um pintor que utiliza-se de todos os recursos à sua disposição, como a sonoridade, a visualidade, a provocação ao logos, mas que não precisa estar presente mais na cena, pois ela o é e ele a é. Diria Camões que "Transforma-se o amador na cousa amada,/por virtude do muito imaginar;/não tenho logo mais que desejar,/pois em mim tenho a parte desejada." Diz Cesário, resolvendo o desconcerto camoniano (que não entende a não plena realização do sujeito, pois que há uma diferenciação entre espírito e matéria, logo, um conflito), que a virtude está no muito experimentar e no viver. Assim, a parte desejada está no mundo mesmo, em plena e atualizada vivência.

Olá! Bons dias! Em março

Que mocetona e que jovem

a terra! Que amor esparso

Corre os trigos. que se movem

As vagas dum verde garço!

Como amanhece! Que meigas

As horas antes de almoço!

Fartam-se as vacas nas veigas

E um pasto orvalhado e moço

Produz as novas manteigas.

Toda a paisagem se doura;

Tímida ainda, que fresca!

Bela mulher, sim senhora,

Nesta manhã pitoresca,

Primaveral, criadora!

Bom sol! As sebes de encosto

Dão madressilvas cheirosas 
Que entontecem como um mosto.

Floridas, às espinhosas

Subiu-lhes o sangue ao rosto. 


\section{OLHOS}

A apoteose da gratuidade estética não deixou de ter efeito nas relações mundanas entre os seres, nos gostos e nas disposições mentais, e contribuiu para forjar certos traços característicos da individualidade moderna. Organizando uma ordem feita ao mesmo tempo de excesso e variações mínimas, a moda trabalhou no refinamento do gosto e no aguçamento da sensibilidade estética; civilizou o olho, educando-o para discriminar as pequenas diferenças, para ter prazer nos pequenos detalhes sutis e delicados, para acolher as formas novas. "

(O Império do efêmero, Gilles Lipovetsky)

Ah! Ninguém entender que ao meu olhar

Tudo tem certo espírito secreto! Com folhas de saudades um objeto

Deita raízes duras de arrancar!

(Nós, Cesário Verde)

Ler alguns poemas de Cesário é assistir, como espectadores privilegiados, algumas questões do século XIX: a ciência e o progresso industrial deixam marcas e são expressas aqui e ali. Tenhamos em mente, por exemplo "O Sentimento dum Ocidental": as novidades tecnológicas, de comportamento, de valores, são observadas, retratadas, refletidas, reconstruídas; a cidade europeia cosmopolita, com tradições e novidades, conflita na visão do sujeito que por ela deambula, e vai resgatando a memória histórica e afetiva em vias de desaparecimento. Em outros poemas, as marcas do avanço técnico aparecem nas ruas, nas lojas, principalmente nas luzes (e no sórdido gás emitido por elas). São nos hábitos e nos costumes, entretanto, que as mudanças mais perceptíveis e refletidas são expressas na poética discutida. E a mudança, em si, e tudo o que significa, que vai concentrando, centralizando e sendo a grande reflexão do poeta em sua obra. Não podemos ignorar outras questões epocais, principalmente porque elas transparecem nas obras de artistas de porte como um Antero de Quental, um Ramalho Ortigão, um Eça de Queirós. Neles, o comentário que se segue mostra-se mais explícito e claro, e nos dá um bom quadro das ideias que circulavam entre os abres e as mesas dos cafés e restaurantes onde se discutiam arte, política e filosofia naquela Lisboa finissecular: 
Doutrinas e filosofias de índole espiritual começam também a ressurgir, tentando assim a filosofia conquistar um novo lugar. As numerosas descobertas a que se assiste fazem deste século uma época criadora, conseguindo-se através de fenômenos e processos naturais o domínio científico. Século da ciência e da técnica, afirma-se a fé na ciência como última consequência de fé na razão que se havia iniciado com o Renascimento. Mas a hegemonia do cientismo trazia também uma concepção desagregadora de valores. A ausência de uma unidade explica-se em parte por um processo de diversas formas de pensar que desembocava num certo caos de opiniões, sistemas e diretrizes. $\mathrm{O}$ excesso de racionalismo que na Alemanha culminava com o idealismo; a filosofia pessimista de Shopenhauer (1788-1860), própria do idealismo alemão, subjetivista, é expressão desse momento histórico. A concepção do universo de tipo religioso e metafísico era rejeitada pelas novas gerações que se direcionam por especulações realistas e positivistas. Os velhos moldes que orientavam a sociedade humana são assim colocados em causa pelo desenvolvimento científico e técnico alcançado ao longo do século XIX. Surge um novo enfoque onde a vida humana não se explica através do pensamento metafísico mas parte da experiência dos fenômenos naturais. O conhecimento vincula-se à investigação. Dentro de uma certa lógica do progressivismo científico e político, o século XIX, com filósofos como John Stuart Mil, Henri Spencer e William James, apresenta um novo empirismo, nomeadamente na Inglaterra, e, fora da Europa, nos Estados Unidos. (NATÁRIO, 2008)

No itálico do trecho acima, ressaltamos uma ideia que já aventamos anteriormente e que aparecerá novamente: a experiência dos fenômenos naturais é o ponto de partida para toda uma conjuntura de explicações sobre o homem e o universo, substituindo o pensamento metafísico. Concretamente, a experiência do fenômeno pressupõe um empirismo sensorial que, sem grandes prejuízos críticos, transborda nos versos e na maneira de constituir a visão deles. Outro exemplo, fora dos versos, dessas ideias transformadas em prática é o famoso desafio proposto por Antero de Quental a Deus, quando, com hora e local marcado, o poeta açoriano declara em Coimbra que irá provar a existência ou não de Deus. Audiência lotada, expectativa em alta, Antero declara em alto e bom som que, se Deus existe, ele teria um minuto para se manifestar. A recusa ao convite, faz Antero "provar", empiricamente, através da experiência sensível, aquilo que a filosofia da época e a posterior, acotovelam-se para conseguir: a morte de Deus. 
Se por um lado há o aceleramento de mudanças fomentadas pela ciência e que se estendem a cada indivíduo, bem como mudanças de paradigmas ideológicas, por outro, a confiança nessa mesma ciência, somente poderia levar o homem à crise. E crise é motivadora de mudanças, algumas radicais: nas artes, que é o campo que nos concentramos, se assiste a uma reação contra o realismo. Na pintura, o destaque vai para o impressionismo; 1874 é a data da primeira exposição dos impressionistas franceses. No final do século, tanto na arte como na literatura, vai imperar o modernismo. Na música, o romanticismo também dá lugar ao impressionismo.

Uma renovação do pensamento da cultura europeia, tentando superar as crises de certezas que se colocavam, surge na Europa Central com um movimento de afirmação e primazia da vida. É uma nova atitude cultural, uma filosofia que põe o acento na vida e seus valores, defendendo uma subordinação do racional ao vital, expressa pelo que se designou «razão vital». O visível império da razão de algumas doutrinas que o século XIX faz surgir com repercussões ainda no século XX, fazendo esquecer ou colocando entre parêntesis o lado espiritual do homem e da vida humana na sua totalidade, levou assim a um cansaço racionalista. A realidade radical do ser humano e a afirmação da vida excede o poder discursivo da razão, ela não é a faculdade única do homem para ver a realidade. A intuição, o instinto, a inspiração poética, o inconsciente, seriam também formas necessárias para atender e considerar. (...) O desenvolvimento da ciência e da técnica e a ideia de progresso como base que o século XIX iniciou foi uma espécie de doce amargo, pois deu a ilusão de que seria possível recuperar na terra o paraíso perdido. (NATÁRIO, 2008)

Esse panorama de decepções e ausência de soluções, largamente prometidas pela ciência experimentalista ou pela filosofia burocrática, somadas às crises pessoais, vai compondo o plano de fundo - quando não é personagem principal, como em O Sentimento dum ocidental de valores, de ideias, de aspirações e intuições, que o olhar verdiano vai captando, remodelando e sintetizando. Plano de fundo, pois não é, em geral, sua preocupação dominante proposições filosóficas, sociológicas ou até políticas. Lembremos o quão desgastado ele fica com a recepção nula ou negativa de sua obra, e também o pouco papel político que se propõe a fazer. Político naquele sentido tão típico da época: jovens liberais, consumindo absinto e tabaco, gravemente determinando a existência de Deus, o melhor sistema econômico, ou a estética mais coerente com o poeta "forte e moderno". Esse posicionamento claramente está em sua obra: daí que ao grande quadro (exceção já mostrada), interessa a ele o pequeno. Nele, intuitivamente e por 
experiência, vai reconhecendo valores e certas alternativas à vida de crise e de niilismo tão amplamente servida nas mesas europeias e, mesmo com certo atraso, degustada com adaptações ao sabor lusitano, com o típico afã de localidades distantes dos grandes centros. É a história, resumida e sem romantismo, da Geração de 70, por exemplo, ou do Grupo do Leão. ${ }^{15}$

Afastado das grandes discussões, Cesário está livre para verificar a vida cotidiana. É verdade que o Impressionismo também já o faz, e mesmo Baudelaire também, ainda que deste a lição que percebe é mais a busca e a tentativa de apreensão da fugacidade do belo, enquanto dos primeiros pintores lhe fica a possibilidade de a beleza representar tão bem o efêmero. É com esse arsenal de ideias, de técnicas, de propostas, que o olhar vai percorrendo a cidade, o campo, as pessoas e, principalmente, a si mesmo. Não surpreende que perceba com detalhes e com atenção o elemento que deu origem a essa tese: a moda. A palavra "moda", no corpus proposto (que é superior a $80 \%$ de toda a obra do poeta), surge literalmente 5 vezes; termos correlatos, como vestimentas, citação sobre estilos, sobre detalhes de beleza, quer em pessoas, lugares ou objetos, surgem de maneira recorrente. "Como arte das pequenas diferenças e das sutilezas do parecer, a moda exprime o refinamento dos prazeres do olho. (...) A moda e o refinamento visual caminham juntos; ela consagra o progresso do olhar estético nas esferas mundanas. " (LIPOVETSKY, 2009, p.73). Adam Smith, um dos primeiros filósofos a conferir à moda um papel central em sua antropologia, afirmou que ela se aplica antes de tudo a áreas em que gosto é um conceito central. Este seria o caso, em particular, de roupas e móveis, mas também da música, da poesia e da arquitetura. Assim, centralidade de gosto (segundo Smith) ou refinamento visual, segundo Lipovetsky (2009), seriam sintomas da moda. Em Cesário, nos interessa principalmente o conceito de "refinamento do olhar", pois sintetiza, em nossa leitura, uma das formas de construir poesia mais utilizada pelo poeta.

Por um lado, o refinamento se produz, como mostra Lipovetsky e como mostramos já na introdução, pela busca ao pessoal, ao adereço, ao efêmero. O brinco, o lenço, a luva, o broche, são exemplos de adereços, mas também o detalhe na estampa, a cor distinta no sapato etc, os seriam. " Refinamento pelo refinamento" é, no entanto, o risco ao se pensar na moda e

15 A Cervejaria Leão d'Ouro, na antiga Rua do Príncipe, hoje Rua $1^{\circ}$ de Dezembro, em Lisboa, é o ponto de encontro, o cenáculo onde se reúnem artistas e literatos, convivendo e animadamente debatendo as ideias e as doutrinas que chegam de França. Daí o nome do grupo que Cesário chega a frequentar, mas por razões de discordância e talvez de falta de sintonia, abandona posteriormente. 
se observar o detalhe: é o detalhismo, o esteticismo, o enfeite. Não vamos muito distante ao mostrarmos que poucos autores percebem o tal efêmero na moda como elemento de individualização: em certa medida, é correto dizer que o imperativo da moda salta aos olhos, impondo todo o seu sistema simbólico-visual de valores e de socialização. Assim a utiliza, por exemplo, o conterrâneo de Cesário, Eça de Queirós. Recurso estilístico extremamente versátil para construção de valores, quer socioeconômicos, quer ideológicos, Eça foi um mestre em tal uso, aproveitando-se para construções verossímeis de personagens que refletiriam o mundo real.

Afora o uso como recurso estilístico que concentra tantas informações, a moda também é um posicionamento "existencial”: na interpretação dada a ela por Roland Barthes: "Cada nova Moda é uma recusa a herdar, uma subversão contra a opressão da Moda anterior. " Vista dessa maneira, a nova moda encerra uma emancipação, pois nos liberta da antiga. O problema é que uma coerção é substituída por outra, pois somos imediatamente submetidos à tirania da nova moda. Baudelaire (1996) descreve cada moda isolada como um sintoma de "um novo esforço, mais ou menos feliz, na direção da Beleza, um tipo de aproximação a um ideal pelo qual a inquieta mente humana sente uma fome constante e titilante”. Pode-se afirmar que Baudelaire, apesar de sua fascinação pela moda, só dá meio passo em direção a ela. Ele quer "extrair da moda todo elemento que ela possa conter de poesia na história, destilar o eterno a partir do transitório". Para ele, a beleza é uma questão de encontrar uma síntese do eterno e do temporal.

A beleza é feita de um elemento eterno, invariável, cuja quantidade é excessivamente difícil determinar, e de um elemento relativo, circunstancial, que será, se quisermos, quer alternadamente ou ao mesmo tempo, a época, suas modas, a moral, suas emoções. Sem este segundo elemento, que é como que o glacê divertido, atraente, apetitoso do bolo divino, o primeiro elemento estaria acima de nossa capacidade de digestão ou de apreciação, não sendo nem adaptado nem conveniente à natureza humana. Desafio qualquer pessoa a apontar um único fragmento de beleza que não contenha esses dois elementos. (BAUDELAIRE, 1996).

Cesário parece fazer uma síntese distinta, já que não descarta o transitório: na verdade, é a partir principalmente do transitório que se perceberia a real beleza. Esta não é necessariamente eterna, transcendental, mas um valor em si mesma. Também não é somente 
simbólica ou alegórica, mas um significado em si mesmo. Assim, traçamos a linha divisória entre o poeta português e o francês, e orientamos esta seção para o que interesse mostrar: o olhar que vê a beleza nas coisas e que, quando vê "através", isto é, o segredo das coisas, nunca é uma transcendência, mas a imanência da realidade. Também é um olhar acurado, que procura o belo no inusitado, no oculto pela sociedade, no pessoal. A moda é o sintoma desse olhar, que perscruta, mas também ilumina; dialeticamente, impõe sombras, assim como mostra-se sedado pela materialidade da beleza.

Que o ato de olhar é fundamental para a apreensão do mundo em Cesário percebe-se pela quantidade de referências a tal ação (ou a visão em si). Sobre esse "olhar", Bachelard (1994) diz que:

"A vontade de olhar para o interior das coisas torna a visão aguçada, a visão penetrante. Ela detecta a falha, a fenda, a fissura pela qual se pode violar o segredo das coisas ocultas. A partir dessa vontade de olhar para o interior das coisas, de olhar o que não se vê, o que não se deve ver, formam-se estranhos devaneios tensos, devaneios que formam um vinco entre as sobrancelhas".

De forma explícita, o poeta deixa claro ser este o seu "sentido" preferido na apreensão do mundo. É perceptível que a ação do olhar não é meramente automática ou passiva: há distintas e por vezes contraditórias formas que tal gesto se manifesta. Compreendemos também que a forma que olha, isto é, os mecanismos linguísticos utilizados, permitem perceber elementos da mundividência autoral. Metonímias, alusões e alegorizações são manifestações concretas que exemplificam tal variedade. Tal qual um pincel, o poeta vai utilizando-se de alguns recursos e, com isso, compondo seus quadros, quer sejam externos, quer íntimos. Por vezes, o pincel está afiado, atento; por outra, parece inerte e entediado. Isso resulta tanto daquilo que pinta, quanto como pinta. Por isso, cabe analisar com detalhes cada polo desse processo, em uma estrutura semelhante a utilizada para pensar na constituição do sujeito. Exporemos os opostos, discutiremos as sínteses e refletiremos sobre o processo em si. Nesse processo, elementos como a moda, a mulher e o "secreto", e principalmente, as marcas da temporalidade surgirão.

\section{Um olho encantado e outro desassossegado}


Milady, é perigoso contemplá-la,

Quando passa aromática e normal,

Com seu tipo tão nobre e tão de sala,

Com seus gestos de neve e de metal.

Sem que nisso a desgoste ou desenfade,

Quantas vezes, seguindo-lhe as passadas,

Eu vejo-a, com real solenidade,

Ir impondo toilettes complicadas!...

(Deslumbramentos)

As duas estrofes inicias do poema Deslumbramentos são exemplos de como olhar voltado exclusivamente para um tipo de beleza torna o sujeito aprisionado das sensações imediatas de tal visão, retirando o sentido de humanidade nele, na mulher que o deslumbra, e na sociedade que o cerca. Nos versos, alguns recursos permitem tais percepções de ideias do poeta: utilizando-se do clichê e da tipificação, retira-se traços de personalidade da interlocutora feminina, a "Milady", e concentra-se a caracterização em tornos de elementos externos, como hábitos, títulos (o pronome de tratamento discutido) ou posturas. É necessário destacar o advérbio exclusivamente, pois neste exemplo estudado, o olhar de Cesário constrói uma personagem feminina sem qualquer elemento pessoal, isto é, desumanizada. A construção se dá por um processo de concentração de referências em torno de alguns elementos, como o vocativo indicado, algum hábito (as "toilettes complicadas") ou outra referência que permita qualificar algo ou alguém dentro de um sistema: no caso, a sociedade. A partir da concentração, há uma distensão que vai reforçando e adjetivando o objeto ou personagem: “(...)gestos de neve e de metal", "(...) tipo tão nobre e tão de sala". Esse processo, formado pela combinação da concentração e da distensão, permite ou o reforço da descrição, valoração e referenciação do objeto concentrado ou a desconstrução, criando um efeito de ironia ou de perplexidade; de qualquer forma, há nesses recursos linguísticos uma maneira peculiar de formar imagens e também sensações, pois faz com que o leitor vá percebendo a totalidade do quadro (usamos e usaremos ada vez mais constantemente tal palavra) a partir de partes específicas.

Ao contrário do que poderia parecer as determinações aqui destacadas, não há um hiperrealismo nessa técnica. Cesário utiliza a distinção para criar um efeito semelhante ao ato da diluição da concentração. Tal qual o artista ao pintar o quadro, ao invés do traço reto e preciso, os adjetivos utilizados também contém em si elementos dinâmicos: os gestos de "neve" e de 
“metal”, possibilitam tanto a percepção visual, quanto tátil da qualidade. O tipo "tão de sala", por metonímia, nos lembra uma postura (ou pose estática), tanto quanto a narração de ações em ambiente mais formal. Nos parece que "o refinamento do olhar" de Cesário capta essas nuances que, isoladamente, são também materializações da beleza. A tipificação, que se vale de características exteriores para a sua construção, em diálogo com as referências sociais, é uma forma da construção da beleza a partir do gosto da sociedade da época: tal visualidade faz com a beleza não seja um conceito e sim uma materialidade. E, de forma coerente, é somente na materialidade que está, de fato, a beleza da mulher mostrada. Mesmo os seus gestos, as "toilletes complicadas", seu comportamento "tão de sala", remetem à etiqueta de determinada classe social.

O fascínio e atração por este tipo de beleza nobre ou que denote classe social superior, com características europeias, ou melhor, com traços distintos da mulher lusitana, e que também se coaduna com a mulher citadina, transparece em outros poemas. Esse fascínio, não é difícil perceber, magnetiza, prende, atrai, concentra o olhar e a vontade do indivíduo. Para o admirador capturado pela beleza da musa, nada além parece existir. Por essa razão e também pelas relações entre esse tipo de beleza e a cidade, é que o indivíduo, em regra, sofre. Estar na cidade é vivenciar e experimentar o fascínio pela beleza que ali se produz e o gosto ali formado. Por consequência, o sofrimento resulta da impossibilidade de um amor motivado e procurado a partir de valores externos. O olhar, nestas circunstâncias, por um lado, permite a captação dessa beleza de forma pormenorizada, mas, por outro, tal qual a beleza da Medusa clássica, instaura algumas crises no sujeito.

Em Humilhações, o sujeito não somente suporta o desdém da mulher amada, como o exagero da paixão faz com que chegue a idolatrar o desprezo: “Esta aborrece quem é pobre. /Eu, quase Jó, /Aceito os seus desdéns, seus ódios idolatro-os;/E espero-a nos salões dos principais teatros, /Todas as noites, ignorado e só. " A humilhação também aparece em Esplêndida, com o sujeito correndo como um louco para acompanhar a mulher amada. Em comum, ambas as mulheres são citadinas, assim como o espaço, e são utilizados os elementos da moda para caracterizá-los, mulher e espaço citadino. Assim, temos ideia da movimentação típica de uma cidade grande europeia, com seus teatros, luzes e carruagens.

Na representação dum drama de Feuillet, 
Eu aguardava, junto à porta, na penumbra, Quando a mulher nervosa e vá que me deslumbra

Saltou soberba o estribo do coupé.

Como ela marcha! Lembra um magnetizador.

Roçavam no veludo as guarnições das rendas;

E, muito embora tu, burguês, me não entendas,

Fiquei batendo os dentes de terror.

(Humilhações)

A crise, ou pior, a não percepção dela, é a síntese de um processo que poderia ser descrito nas seguintes etapas, perceptível em diversos poemas ou situações em que o gesto do olhar magnetiza, seduz o sujeito ao mesmo tempo que o seda, o coisifica, o desumaniza: na primeira etapa, há uma admiração sem limites para a beleza física da mulher; na segunda, sem o olhar para outro tipo de beleza que não a física, o sujeito vai, pouco a pouco, se descaracterizando, neste caso, se coisificando; por último, há um processo de ruptura com tal estado, para uma raiva (Humilhações e Esplêndida), uma aceitação polêmica, irônica (Deslumbramentos e Vaidosa), uma vã esperança de união impossível (Caprichos). O que significa tal rompimento? Será que mesmo em poemas 'baudelairianos", ultrarromânticos ou de moldes trovadorescos, isto é, com tantas marcas de estilísticas e de mundividência marcada, há, mesmo que ainda de maneira hesitante, aquela percepção de uma beleza que, sem a inicial maiúscula da idealização, é experiência real da vida cotidiana? Nos parece que o processo de ruptura é a não aceitação de tal beleza, mesmo que ainda sem posicionamento definido e definitivo do porquê ou como solucionar algumas angústias causadas por este olho que sonda e que procura.

Partindo do extremo caso da coisificação entrevista em Caprichos, publicado em Lisboa no Diário de Notícias, em 22 de março de 1874, e que aparece como o $6^{\circ}$ poema na edição de Silva Pinto (2003), com o já mencionado título Responso ${ }^{16}$, vemos um sujeito que, estrofe após estrofe, em uma estrutura de quatro versos e um dístico (ou responso)aos versos, concentra-se

\footnotetext{
16 O poema está na primeira "parte” do livro: Crise Romanesca. Apesar da crítica em geral ser desfavorável à edição de Silva Pinto, a leitura e a organização realizada não conflita com as posições estéticas ou filosóficas de Cesário, e são pessoais ao editor, como são todas as análises e críticas realizadas, mesmo as mais "científicas". A inclusão de subtítulos, as supressões, a troca de títulos, a inclusão de oferecimentos, são, no entanto, opções típicas dos editores da época e, dentro desse contexto, compreensíveis.
} 
em captar cada gesto, cada detalhe da beleza da mulher, cada momento dessa percepção, e, em resposta, vai, repetidamente, em tom propositalmente monocórdico, pede ou mostra o desejo de se tornar algum objeto, astro ou serviçal, para poder aproximar-se e tocar a amada.

Num castelo deserto e solitário

Toda de preto, às horas silenciosas,

Envolve-se nas pregas dum sudário

E chora como as grandes criminosas.

Pudesse eu ser o lenço de Bruxelas

Em que ela esconde as lágrimas singelas.

O uso no dístico do pretérito imperfeito do subjuntivo para mostrar o poder/ser do sujeito expressa aquilo que é, em si, uma impossibilidade, mais do que um desejo. Todos os dísticos, tal qual o responso, é a cristalização da contemplação, sem freios e sem limites, da beleza feminina. Nas respostas, o afetado e seduzido sujeito, vai imaginando e desejando eliminar as distâncias desse amor impossível: essa cisão entre eles, não é somente de posição social. A posição é construída a partir do intertexto com a cantiga de amor trovadoresca, mas é, dentro do poema, também erigida a partir de elementos espaciais e temporais. Utilizando dois tempos verbais distintos, o presente do indicativo nas ações da mulher $\mathrm{e}$ na observação/imaginação/sonho do sujeito, e o pretérito imperfeito, e dois modos também distintos, o já explicado indicativo e o subjuntivo, os tempos se afastam e afastam os sujeitos. O olhar, carregado desse posicionamento que é ao mesmo tempo histórico e atualiza-se, no poema, como uma espécie de devaneio entre uma desilusão amorosa real, no sentido de próxima, e seus cognatos: desilusões que aconteceriam repetidamente, fazendo o tempo histórico antigo repetir-se atualmente (na atualidade do poema).

Nos tipos de construções poéticas em que há um intertexto tão marcadamente explícito, as cargas ideológicas, além das marcas estilísticas e de textualidade, também estão presentes. A visão de mundo medieval condensada nas cantigas de amor não discute somente a impossibilidade da realização amorosa pela distância social entre o amador e a sua amada: há também e principalmente um distanciamento moral. A moralidade lá expressa é derivada da 
ética cristã que orienta ao amor casto ou ao distanciamento de um amor proibido: esta, claro, é derivada do Nono Mandamento - não cobiçar a mulher do próximo. Entretanto, se a cantiga medieval é duplamente um impedimento, e um reconhecimento tácito da impossibilidade da realização amorosa, pelas características do gênero poético, o poema verdiano rompe com alguns desses elementos, pois não se trata de mera cópia de cantiga e sim um fazer artístico já que a intertextualidade é material artístico inerente a qualquer obra de arte que assim se queira chamar.

A explicitação da espacialidade, um “ castelo deserto e solitário”, é, em relação ao gênero poético medieval especificado, um dos indícios de rompimento. Se lá, a espacialidade é presumida e aludida, pelas referências em termos de posicionamento dos atores do poema e da linguagem utilizada, bem como da postura esperada da vassalagem amorosa, cá, no poema cesárico, é a espacialidade que contextualiza o leitor da situação. Essa espacialidade, do castelo deserto e solitário, atualizada, torna-se mais alegórica do que real, mas é o ambiente adequado para a construção da situação, que, em quatro versos, são primorosamente descritos, a partir da concentração: o espaço, o tempo, a situação e o estado de alma da amada. Cada um desses elementos, observados minunciosamente, vão formando pequenas cenas, que, por sua vez, se articulam com outras e outras, até o poema em um todo. Esse olhar que recorta e concentra vai, por alusões, mostrando a situação de afastamento do mundo da mulher admirada, a partir da cor da roupa ("Toda de preto"), de suas ações ("Envolve-se nas pregas dum sudário") e do seu estado de espírito ("E chora como as grandes criminosas"), que é inferido a partir dos pressupostos dados, mas também exige do leitor a visualização dessas alegorias e o resgate de possibilidades semânticas. Sem o reconhecimento do gênero aludido, e por consequência, sem a participação na interpretação, o poema se perde em descrições um tanto quanto vazias. Tal participação, por outro lado, como em outros casos do próprio poeta, em que a visualidade é também simbólica, além de sensível (principalmente criando sensações), aproxima o leitor da coisa "vista”, fazendo que a interpretação não seja somente lógica, mas também sensorial.

Expressar tais elementos - espaço, estados, ações, tempos - e harmonizá-los para potencializar cada um deles, coloca o leitor na cena, e também, retoricamente, estimula e provoca o pathos aumentado a adesão do leitor à cena descrita. Quando dizemos retoricamente, pensamos menos no objetivo de convencer pelo logos, do que aproximar e criar uma situação de vivenciar as ideias e os valores, pelas suas materializações. Dessa forma, os quatro versos não são somente a descrição da cena, mas também a já experimentação das sensações por ela 
provocadas. No caso do sujeito dentro do poema, essa imersão nos detalhes o seduz de tal maneira, que ele deseja somente ser um prolongamento, mesmo que coisificado, da cena em si, e relacionar-se, passivamente, com a mulher desejada e admirada. O prolongamento, no caso, diluiria a distância temporal, ao colocar o sujeito, no presente da ação. Cabe pensar que esse recurso cria um efeito e um estado de permanência: ao observarmos um quadro, admiramos a cena em si, e, incidentalmente, quando não se trata de pessoa ou situação conhecida, historicamente datada, temos a sensação atualizada, da maneira que o artista pretendeu manejar e constituir, assim como temos, de certa forma, a mesma visão. O tempo da visão, da confecção, da admiração, se tornam, neste instante, o mesmo. A suspensão do tempo, que percebemos no presente do indicativo, mas é potencializada pelo o que estamos demonstrando, é a captura do efêmero. Sobre isso, dedicamos todo um capítulo (“AÇÃO”). Por ora, continuemos a compreender o olhar, na situação corrente.

Encantado pela olhar concentrado na beleza, sedado pelo efeito dessa concentração e, então, destituído de sua identidade, é a manutenção desse efeito, que é deleite dos sentidos acima de tudo, que proporciona algumas situações que, vistas à luz somente da razão, oferecemse como quadros problemáticos de valores: daí a crítica desprezar tais situações, postas que estão a observar a partir de um lugar próprio - o de homens "sérios"- e tendo a poesia como função, principalmente então, de censura, investigação ou condenação da sociedade(é famosa a analogia entre a caneta e a espada presente, por exemplo, em Antero de Quental). Decerto, é pouco "espada" a proposta deste poema, assim como o é Esplêndida, com situação análoga. Também podemos colocar outros poemas que executam com tom e andamento similar aos que vemos na mesma categoria pouco interessante aos escritores e críticos contemporâneos a Cesário: a da flauta doce, que toca o desconcerto amoroso do homem comum, sob o aggiornamento próprio das questões finisseculares do XIX. Nessa perspectiva, há de se admirar o esforço na manutenção e na expressão de uma beleza que, em comparação ao real, isto é, aos desencontros amorosos do cotidiano, adquire cores e melodias elevadas. Que se entenda que estamos focando na substância e não no acidente: o amor e não o "doentio", "sadomasoquista", "inútil", "burguês". Seguimos o próprio poeta, que, com seu olhar secreto, retira os acidentes, reinterpreta-os, reelabora-os e mantém a substância.

Entretanto, o desejo, como o expresso pelo sujeito em algumas situações, é, de fato, completamente egocêntrico e inclinado a também esquecer da amada e concentrar-se no amante. A mulher desejada só tem utilidade enquanto satisfação das vontades do amador. Essa 
perspectiva, diluí a noção do amor (ARISTOTELES, 2011), já que "Amar é querer um bem para o outro" e é afirmar o "outro enquanto outro", enquanto alegra-se pelas realizações, pela completude e a afirmação do bem que é a existência do outro (STORCK E ECHEVARRÍA apud POLO, 2005). O deleite dos sentidos produzidos é o prazer, isto é, o amor produz prazer, que é, segundo Aristóteles (2008), gozo ou deleite que se experimenta ao seu possuir aquilo que é procurado ou realizar aquilo que se quer. Pode-se nomear esse tipo de prazer de prazeresnecessidade (ARISTÓTELES 2008; LEWIS, 1991) e nascem de possuir aquilo que se necessita, sem desvirtuar, como explicado, as características do outro, ou idealisticamente, a busca pelo equilíbrio onde haja plena realização dos envolvidos, pela manutenção daquilo que eles são e no ato de amar. Nesta parte, concentrados que estamos no olhar desequilibrado, cabe ainda mostrar alguns aspectos estilísticos que revelam tal desarmonia. Um deles, é a utilização de elementos da modernidade como metáfora ou comparação; o outro, são elementos ligados à morte; por fim, o uso de referências a cores e ambientes específicos. O poema Vaidosa ${ }^{17}$ é um exemplar do uso de tais recursos, além de outro que cabe destacar: a ironia. Mesmo sendo um poema pouco conhecido e com largo uso de apropriação de lugares-comuns, de soluções estilísticas de outras lavras ou mesmo epocal, e de alegorizações óbvias, há, além da ironia, um recurso próprio e de uso particular em Cesário: a contraposição de elementos de tempos, espaços e valores distintos e distantes, perfazendo um efeito de diluição de tempo não pela ação explícita, mas pelos valores históricos de tais elementos. Falaremos disso em "AÇÃO: A vida contida do tempo".

O problema da concentração do olhar é que ele, ao mesmo tempo que revela, reduz: por processos de metonímias, Cesário, em regra, mostra sempre a mulher por partes: os olhos, o peito, a boca, as mãos, os pés. Tai usos são tão recorrentes que fazem parte de sua poética e expressam como o olhar pode também perder-se em tais concentrações:

O fetichismo de Cesário consiste, sem novidade na sua definição, numa perversão comum, geralmente identificada no homem, que o faz idolatrar não a mulher que deseja mas uma parte dela ou um objeto de seu uso. Assim o vemos,

\footnotetext{
${ }^{17}$ Publicado em A Harpa, $\mathrm{n}^{\mathrm{o}} 14,1^{\mathrm{a}}$ série, na cidade do Porto, inexiste na edição de Silva Pinto, apesar de poder pertencer, segundo a lógica utilizada pelo crítico, as tais Crises Romanescas. No entanto, sabe-se, pela correspondência trocada com Cesário, que não o apetecia finais irônicos, preferindo a crítica mais explícita.
} 
respectivamente, a desejar uma parte do corpo beijar lascivamente o pulso da mulher ou a desejar uma parte do vestuário os seus "vestidos afogados" (CEIA, 1995)

Entretanto, em algumas situações, além desse gesto em que seu olhar se perde no feitiço da parte feminina, tal concentração, paradoxalmente, também consegue revelar dois aspectos presentes na mesma situação ou objeto. Como que se sondasse e percebesse dicotomias inerentes em algumas coisas, utiliza-se dessa técnica, revelando no detalhe mundos opostos e implícitos, mas que, por um processo de síntese, conseguem bem representar aquilo que pretende. Esse é o caso do uso de nomes femininos com dupla acepção ou outros léxicos, em que, principalmente o sagrado e o profano coexistem. Não somente isso: também é pelo olhar que percebe que as oposições semânticas estão subscritas em muito daquilo que vê ou que decide ver. Ao percebê-las, há, ao mesmo tempo, a suspensão dos valores, já que falamos de polos dicotômicos que somente agora existe enquanto dialética, isto é, dinamicidade de sentidos. Essa suspensão cria um efeito não somente de plurissignificação, mas também exige que o olhar do leitor vá de um polo a outro, initerruptamente, impedido de fixar-se somente em uma definição semântica, para dar conta da paleta de significados possíveis de serem apreendidos. Nesse momento, em que o olhar vai de lá para cá e assim continuamente se movimenta, o significado se presenteia ou se atualiza a cada movimento - como dir-se-ia mais tecnicamente - se contextualiza.

Sendo esse o movimento e o efeito conseguido a partir da concentração (e da distensão), os valores ideológicos, os efeitos sensíveis, a própria temporalidade, coexistem à medida em que são lidos, criando um segundo efeito, mais importante, de suspensão: da distância entre o ato da escrita e o ato da leitura nada mais se apercebe, além do efeito em si. Somente que, nesse caso, a vontade de anulamento de distância faz parte da mundividência verdiana, mas apresentase até no menor elemento - o léxico. Não se trata somente de perceber o ato interpretativo como constituinte da obra - e o é, dirá Pareyson e outros: é perceber uma poética que busca, pelos detalhes, a apreensão desse elemento efêmero: a sensação causada pela coisa em si. Isso dito, também podemos voltar para a questão do fetiche e reelaborarmos que, o recorte (a metonímia) que se utiliza, também pode ser visto como a forma mais "cinematográfica" de se construir o feminino: através das partes, deixar com que o leitor vá construindo o todo. Essa questão em si, não anula o fetiche, mas tira do campo da pura perversão o uso da metonímia, utilizando-a como um recurso de linguagem em que a beleza está concentrada e, nesta concentração, torna-se ainda mais requintada pelo detalhe. Como segunda explicação para ampliarmos o fetiche, e essa é 
coerente com a poética discutida, o mostrar "parte" por "parte", alonga o tempo para que se perceba a mulher: esse alongar o tempo, como que, a conta-gotas, o belo fosse sendo desvelando, é, claro, potencializador do erotismo, mas dilatador da sensação.

Ao pensarmos nessas questões, pode-se abordar algumas situações a partir delas. Como primeiro estudo e contextualização de tais ideias, vale a pena principiarmos pelo primeiro verso do poema Cantos da Tristeza: nele, é nos dado a conhecer o nome da interlocutora do sujeito, pelo uso do vocativo ("Helena”), mas sabemos também, desde o princípio, de sua condição "triste", e de uma certa indefinição dela própria, nesta passagem em que há a presentificação do diálogo e um distanciamento, devidamente a esse recurso, daquele “(...) tempo da colheita dos bons vinhos. " Estrofe após estrofe, o sujeito se dirige a ela, rememorando as inúmeras condições idílicas amorosas realizadas, como se tentasse, quadro após quadro, frase após frase, imagem após imagem, suscitar alguma reação dela, que aparentemente é de indiferença. Tal indiferença se mostra no "talvez" repetido à exaustão, que coloca em suspeição as memórias ou sentimentos de outrora, que o amado tanto tenta resgatar.

Talvez já te não lembres, triste Helena,

Dos passeios que dávamos sozinhos,

À tardinha, naquela terra amena,

No tempo da colheita dos bons vinhos.

A "triste Helena" e outras figuras produziram, e não o podemos ignorar, farta fortuna crítica, que, em certa medida, aqui também transparece, quer formativamente, isto é, nos calabouços da memória do intérprete, quer literalmente, como cabe apontar agora. Dos estudos, dois obviamente ecoam e ecoarão, mesmo dialeticamente ao pensarmos o "Tu" em Cesário. Um deles, o de Helder Macedo (1988), analisa a presença do erotismo em sua poesia, que em ambiente citadino ou campestre (que se desloca para os elementos da natureza) ou expresso através de um desejo que se exacerba nas ruas, focaliza a mulher como objeto de desejo, o que caracteriza um novo modo de se estar em público. Essa mulher e o desejo por ela, alteram o comportamento e o posicionamento do sujeito. Para Mário Praz (1996), isso corresponde a uma inversão pois, no início do século, prevaleceu o herói byroniano, o homem fatal, que submete a mulher a seus caprichos e, na segunda metade do século XIX, a mulher fatal irrompeu na 
literatura, por meio do exotismo, como projeção fantástica de um erotismo exacerbado e da presença de mitos antigos, como Esfinge, Afrodite ou Vênus.

Em geral, a crítica vê no erotismo verdiano a contraposição entre cidade/campo, criado/senhora, associando a cidade a um erotismo de humilhação, acompanhado de um desejo impossibilitado de realizar-se, enquanto, no campo, os desejos eróticos são libertadores, para o sujeito poético, como discute em sua tese, NASCIMENTO (2003):

O erotismo, na poesia de Cesário, é difuso: chega à mulher fatal urbana, mas se desloca para a mulher campestre. Apesar dessa última figurar nos versos verdianos como uma criatura simples e pura, ela também se torna alvo do olhar erótico. Há ainda o erotismo despertado pela mulher feia, como ocorre com a vendedora de verduras do poema "Num bairro moderno", ou mesmo por um tipo masculinizado da mulher rural, como ocorre no poema "Manhãs brumosas", no qual o poeta descreve o feminino com características de um "rural boy". A presença de Eros, deslocado para uma multiplicidade de lugares que não diretamente o corpo feminino, mas que se associa a ele, aparece também no poema "Provincianas", de temática campestre, no qual Cesário está a ler a paisagem como um enorme corpo feminino, que mostra a explosão do amor e da saúde, qualidades do mundo campestre. Nesse caso, os relevos transformam-se em seios e a paisagem dourada conforma-se à imagem feminina: "Bela mulher, sim senhora,/Nesta manhã pitoresca, Primaveril, criadora!/ Cresce o relevo dos montes, /Como seios ofegantes, Murmuram como umas fontes /Os rios que dias antes/ Bramiam galgando pontes." Ressalte-se que os seios femininos são recorrentemente tematizados no erotismo de Cesário, como no poema "De tarde", que apresenta um campo, sob uma perspectiva urbana, pois trata-se de um pic-nic. Há, ainda, outros elementos do poema que nos fornecem indícios de uma visão urbana sobre o campo, como a própria indumentária feminina de conteúdo erótico, com rendas e decotes.

Não é tratar de ignorar toda carga erótica percebida, mas revê-la em linha condizente com o que está se desenrolando aqui: haveria somente dois polos - a pura e a impura, a sans 
$m e r c i^{18}$ e a santa ${ }^{19}$, em uma estrutura dicotômica ou, como também pensado na estruturação do $e u$, uma síntese? Existindo a síntese possível entre tantos tipos femininos, marcadamente construídos em dois polos, qual seria tal síntese e como se desenvolveria em termos de construção das figuras femininas? Há dois casos em que se dirige a interlocutora pelo nome próprio: no poema em questão (a Helena) e em Melodias Vulgares temos conhecimento de uma Clarisse. O primeiro nome tem origem com o grego Heléne, a partir de heláne, que significa "tocha". O termo hélê quer dizer "raio de Sol", fazendo com que o significado de Helena seja "a reluzente" ou "a resplandecente". É das mais conhecidas a lenda da Helena de Tróia e sua beleza. Além disso, Helena aproxima-se de helenismo, característica apreensível na arquitetura poética aqui lida, mas nem tanto nas soluções. Por isso, cabe pensar também em uma homônima, menos imediatamente aludida, não pela falta de evidência: Santa Helena, mãe do imperador romano Constantino, falecida em 338. Esta personagem histórica foi homenageada pelos ingleses com 135 igrejas dedicadas exclusivamente a ela. Foi um nome adotado inicialmente pelos primeiros cristãos para homenagear a santa, se tornando muito popular no País de Gales, mas só chegou à Inglaterra após a conquista normanda, sob a forma Elena. Clarice é derivado do nome próprio Clara, que por sua vez é uma variação do nome Clarissa. A raiz etimológica deste nome está no latim clarus, a partir do adjetivo clara, que significa "brilhante" ou "luminosa". Santa Clara de Assis ${ }^{20}$ é a fundadora das Clarissas, (antes chamadas de senhoras pobres), com conventos espalhados por vários lugares da Europa e uma espiritualidade voltada para a pobreza, a oração e a ajuda aos mais necessitados. Há outras diversas referências históricas femininas, mas estas, como exemplo daquele polo das mulheres fatais urbanas: “(...)Dubarry, Montespan e Maintenon/Se a vissem ficariam ofuscadas”. Também se menciona Ana de Áustria em Deslumbramentos. Nesses casos, a referenciação cria

18 “(...) o seu ideal feminino parece ter sido, pelo menos nos princípios da sua actividade poética, a mulher glacial e distante(...). O poeta sente-se atraído pela 'belle dame sans merci' que tinha fascinado Keats e outros poetas românticos ingleses e franceses.(...)Estamos perante a femme fatale que tanto inquietou os artistas europeus na segunda metade do séc. XIX sob nomes variáveis: a Salomé de Wilde, a Carmen de Mérimée, a Salambô de Flaubert ou a Jeanne Duval de Baudelaire. A 'dame sans merci' de Cesário subjuga o adorador e concede-lhe apenas o papel de servo incondicional(...)." LIND, Geroge Rudolf. "O real e a análise”: o mundo poético de Cesário Verde. Colóquio Letras. No. 93. Setembro de 1986, p.31.”.

19 "Nos seus inícios ultra-românticos Cesário não se sente somente atraído pela femme fatale, mas também pelo pólo oposto desta, a femme fragile, a mulher etérea, angélica e quase santa, o ideal dos prerafaelitas ingleses." Ibidem, op.cit., p.32.

${ }^{20}$ Num Domingo de Ramos, dia 18 de março de 1212, uma jovem, aos dezoito anos de idade, foge da casa de seus pais e se encaminha para a igrejinha da Porciúncula (na atual basílica de Santa Maria dos Anjos), onde São Francisco de Assis e seus Frades, em oração, aguardavam sua chegada. Ali mesmo, em presença de amigas e dos religiosos, São Francisco lhe corta os belos cabelos loiros. 
um distanciamento, além de toda carga crítica possível de ser encontrada, já que as mulheres mencionadas seriam representantes do Ancièn Regime e Cesário é um crítico desse regime. Menos a questão de adentrarmos nas veredas da arte como política, o que não faremos, pensemos na arte como ética e como tal referenciação é, paradoxalmente, uma posição.

No poema Vaidosa, note-se que a estrutura em quartetos decassílabos repete-se em 4 das 5 estrofes: esta última, tem o recurso da linha acrescida anterior ao último verso, criando uma pausa mais acentuada para a conclusão que se fará; e dentro desse verso, ainda outra pausa, utilizando as reticências, para a conclusão, que, surpreende pela ironia e é também uma definição de vaidade: amor-próprio. Nesse poema, os verbos que iniciam os quatro primeiros quartetos, à princípio, afastam aquilo que é dito da mulher ao que é percebido pelo homem: tal situação nos dá um embate de vozes. Há as de um coletivo e há as do eu poemático, que, no que concordam com a beleza e com a postura da mulher observada, posicionam-se diferentemente, já que o sujeito se confessa completamente sedado por ela, enquanto há nas vozes coletivas, um certo senso distante, baseado nas aparências. Como a intimidade parece ser uma concessão ao eu-lírico, o que ele percebe, o amor-próprio, deixa de ser um "diz-que-diz", para ser uma confirmação. A aparente "pureza", mesmo que fria e distante, esconderia aos nãoeleitos, uma mulher que “(...)como um ópio/Me matas, me desvairas e adormeces”, e que tem uma comparação entre sua beleza física, aparente, com a messe, retirando desta palavra, elementos para caracterizar o feminino: a beleza dela o lembraria também do momento da plenitude da seara, com o seu dourado do trigo ou de grãos plenos. É uma forma inusitada de ressaltar a plenitude também física da mulher, já que aludiria tanto o aspecto estético quanto nutricional ou prático da messe. Além disso, como faz parte do vocabulário e obviamente tem raízes profundas, ainda que combatidas, a visão religiosa da messe também é perceptível: em sentido figurado, a messe representa a conversão das almas na visão cristã. No poema, a conversão do sujeito em amador.

\section{VAIDOSA}

Dizem que tu és pura como um lírio

E mais fria e insensível que o granito,

E que eu que passo aí por favorito

Vivo louco de dor e de martírio. 
Contam que tens um modo altivo e sério,

Que és muito desdenhosa e presumida,

E que o maior prazer da tua vida,

Seria acompanhar-me ao cemitério.

Chamam-te a bela imperatriz das fátuas,

A déspota, a fatal, o figurino,

E afirmam que és um molde alabastrino,

E não tens coração, como as estátuas.

E narram o cruel martirológio

Dos que são teus, ó corpo sem defeito,

E julgam que é monótono o teu peito

Como o bater cadente dum relógio.

Porém eu sei que tu, que como um ópio

Me matas, me desvairas e adormeces,

És tão loura e dourada como as messes

E possuis muito amor... muito amor-próprio.

À plenitude física pressupõe-se o tempo do declínio: a messe, se não colhida em seu tempo, perde o vigor e torna-se coisa perdida, pela ação do tempo. Outro léxico tem também essa dupla acepção: fátua. Diz-nos o dicionário HOUAISS (2011) sobre três possibilidades semânticas, todas aderentes ao modelo feminino representado: "1. Muito estulto e com alta opinião de si próprio; vaidoso e oco; presunçoso", "2. Que é tolo, insensato", "3. Que permanece por pouco tempo; que é fugaz, transitório". O lírio também é lido em tais chaves, como objeto belo e fugaz, mas como é figura de comparação com a mulher, além de adjunto adnominal de "pura": pura, empresta suas características para lírio e vice-versa: a comparação não se traduz, como a metáfora, em apagamento de um termo, mas em soma das características entre eles, preservando no termo comparado suas características constitutivas. Assim, a pureza 
do lírio também se verifica em sua referência religiosa ${ }^{21}$, presente em diversas passagens bíblicas. Observe-se também a contraposição entre os elementos "vivos", por consequência, "efêmeros" e dados às mudanças físicas com os elementos "mortos" ou mecânicos: "granito", "molde alabastrino", "estátuas", "relógio", "cemitério". Tais campos semânticos opostos estabelecem relações dicotômicas extremamente dinâmicas, pois que tudo se trata da mesma mulher e situação, e não distintos momentos ou distintas mulheres: assim a dinâmica percebida pelas oposições morte e vida, o mudança e imobilidade, fisicidade esteticamente bela e comportamento reprovável e distante, são percebidas em grande parte pelo olhar encantado, mas colocadas em suspensão pelo olhar desassossegado. Esse recurso consolida-se de diversas formas, mas, generalizando, criando uma cisão entre o que se mostrada por um olhar- a beleza, a sedução, o deleite, - e o que o outro desconfiava: ao nível do desenvolvimento lógico de alguns poemas, tal cisão, entre um olhar e outro, entre o que admira, e o que desconfia, desenrolam-se até um final que não pode ser definido como posicionamento único ou definitivo das ideias, das ações ao que se propõe discutir. Ao incluir a ironia (em Vaidosa e Cantos da Tristeza), a voz social (como a que está em Deslumbramentos ou Humilhações), ou romper com o que se dizia até então, como em Nevroses, a suspensão entre uma forma de olhar e outra somente é resolvida por um terceiro olhar: o de quem vê após e de fora. Se nos concentrarmos somente em um polo, o do sujeito que olha a beleza, teremos uma formação ideológica; o mesmo acontece se olharmos somente o polo oposto: ao fim, ao vislumbrarmos tais polos em uma relação dinâmica, todos os sentidos se constroem sem possibilidades de verdades eternas ou definitivas. Ferraz (1987) fala sobre tal recurso:

"É precisamente pelos fins do século XVIII, por causas inerentes ao próprio abalo sofrido pela poética, que a ironia vai conquistar o seu direito de cidadania na literatura. Não por acaso, a ironia ganha crescente autonomia formal nos alvores da época dita romântica. Tal independência coincide, afinal, com o momento em que na literatura o 'autor' não só é capaz de se apresentar dentro da obra, mas toma consciência (e assume essa consciência no seu modo de fazer literatura) de que é não só o autor, mas o criador de um 'organismo' e não apenas o veiculador de um código mimético que a poética impusera de maneira mais ou menos sistemática. A autonomia formal da ironia

${ }^{21} \mathrm{O}$ lírio é usado em todo o mundo, mas especialmente em países europeus, como símbolo de Nossa Senhora. A brancura e a beleza do lírio é um símbolo da pureza de Nossa Senhora. Além disso, aparece em Cânticos dos cânticos como referência à noiva de Deus, isto é, a igreja. In: http://www.afecatolica.com/products/simboloscatolicos/ Acesso: 15/12/016 
processa-se quando mal se começa a perceber que a obra literária não é só, ou sobretudo, uma interpretação/representação \{mimese) do universo (real ou poético), mas, mais do que isso, um modo peculiar de a linguagem form(ul)ar um universo; a própria linguagem é o mundo. Donde que a obra, como linguagem formadora de um universo, se possa ter tornado antinômica até ao absurdo, percorrida que foi toda uma gama de tentativas de síntese entre essas duas realidades palpáveis - a realidade das palavras e a realidade do mundo(...). Esse primeiro momento de uma procura intensa da síntese entre o real e o fictício, entre o transitório e o perene, entre corpo e mente e a teorização dessa procura deram afinal o romantismo. Essas antinomias levam até à esperança de libertar a literatura da 'prisão da forma'. Que mais é isto senão a insistência na expressão do inefável, autêntico paradoxo de uma época que desperta para a consciência da linguagem? Não parece assim tão inusitado dizer-se que a característica primeira do romantismo é assumir da ironia como princípio necessário e inevitável da expressão estética."

Já em Deslumbramentos, o tom final adotado é de sarcasmo e ameaça: a mulher, elevada anteriormente por sua beleza, porte e estirpe, agora sofre pela imagem de um futuro que o sujeito descreve com detalhes sórdidos: o admirador, pela postura distante da mulher, rompe definitivamente com a beleza sedutora em direção a uma espécie de justiça social. $\mathrm{Na}$ impossibilidade de ele criar a ordem, prefere o discurso histórico da revolução, transferindo para uma suposta massa revoltada e humilhada, o direito e o futuro das figuras que, como a mulher, representam um ideal nobiliárquico ou da alta burguesia. Essa solução textual, de quebra como aquilo dito anteriormente, parece tentar redimir o encantado da beleza para os problemas sociais e históricos que se escondem ou se maquiam por trás de tanto deleite sensorial e estético, como um mea culpa ou uma confissão da fraqueza do sujeito pelo belo e de sua tentativa de manter sua dignidade ou recompor-se.

Mas cuidado, milady, não se afoite,

Que hão de acabar os bárbaros reais;

E os povos humilhados, pela noite,

Para a vingança aguçam os punhais.

E um dia, ó flor do Luxo, nas estradas,

Sob o cetim do Azul e as andorinhas,

Eu hei-de ver errar, alucinadas, 
E arrastando farrapos - as rainhas!

(Deslumbramento)

Esse modelo de ruptura também é apresentado no poema Humilhações, em que, o sujeito enamorado e encantado pela beleza da atriz, tem interrompida a sua admiração pelo "mundo real", constituído de guardas e especialmente, de mulheres que não atendem aos atributos que tanta admiração lhe causam. Neste, diferentemente do anterior, não há uma suposta revolução a caminho, mas uma sociedade em que as diferentes classes já estão em embate. É esta luta que "resgata" o sujeito enamorado do devaneio puro, do ensimesmamento e de uma alienação do mundo. Quem o diz, no entanto, não é o próprio sujeito, mas a ações do poema. Indiretamente, há uma tomada de posição distinta daquela que estava em processo de construção, mas cria-se uma impossibilidade de definição única dos valores ali expostos, tal qual se o filtro que se vê as coisas fosse um caleidoscópio que fragmenta a realidade em partes distintas, distorcendo-a. A realidade é aquela, mas o que se diz dela é variada. Quer por ironia, por sarcasmo, por negação explícita ao que se diz, a instabilidade de significados é propositalmente um recurso poético que na obra cesárea exige que a solução sintética, aritmética ou monocular se amplie para a variedade, a surpresa, o inesperado, o escondido. Poesia da instabilidade, ao nível lexical concentra-se e amplia-se de forma sistemática, carregada de campos insuspeitos de oposições e ampliações significativas; ao nível de solução ideológica ele também se apresenta para além das respostas fechadas e fáceis; ao nível do objeto que pretende mostrar, o belo, terminamos desconfiados do quanto entendemos tal conceito e o quanto o que pensamos ser belo realmente o é.

Que desvanecimento! A pérola do Tom!

As outras ao pé dela imitam de bonecas;

Têm menos melodia as harpas e as rabecas,

Nos grandes espetáculos do Som.

Ao mesmo tempo, eu não deixava de a abranger;

Via-a subir direita, a larga escadaria

E entrar no camarote. Antes estimaria

Que o chão se abrisse para me abater.

Saí: mas ao sair senti-me atropelar.

Era um municipal sobre um cavalo. A guarda 
Espanca o povo. Irei-me; e eu, que detesto a farda,

Cresci com raiva contra o militar.

De súbito, fanhosa, infecta, rota, má, Pôs-se na minha frente uma velhinha suja,

E disse-me, piscando os olhos de coruja:

Meu bom senhor! Dá-me um cigarro? Dá? ...

(Humilhações)

\section{Um olho no elevado e outro no humilde}

Sempre uma coisa defronte da outra, Sempre uma coisa tão inútil como a outra, Sempre o impossível tão estúpido como o real, Sempre o mistério do fundo tão certo como o sono de mistério da superfície, Sempre isto ou sempre outra coisa ou nem uma coisa nem outra. (Fernando Pessoa - Tabacaria)

Em Cesário Verde, as palavras se espelham para tentar fixar um sentido entre sentidos antitéticos, num vai-e-vem ritmicamente controlado, porém semanticamente complexo e diverso. A própria palavra, isolada, é manancial polissêmico; em conjunto, teriam possibilidade de ampliação de significados, mas não em diversas direções: graças à escolha calculada, essas palavras tendem a se confrontar em um esquema dicotômico, que se inicia pela própria oposição que os sentidos dessas palavras contêm. Já discutimos anteriormente que tal escolha deriva do olhar apurado, herdeiro do refinamento próprio de um sujeito subscrito em um contexto sócio histórico tão particular, quanto de um homem em que a atenção aos detalhes e o pensamento ordenador, deixam reflexo também no seu fazer poético. Ao nível textual, essas palavras irão construir diversas formas de representações do mundo. Uma dessas representações concretizase na perspectiva do chamado confronto entre o Sublime e o Humilde. Usaremos ambas as concepções com inicial maiúscula apenas como distinção de uma mera adjetivação. Não que também não o sejam. São, entretanto, conceitos que ganham certa complexidade, desde a Grécia Antiga. No limite deste texto, considerando desde já um corpus reduzido, mas significativo para tal análise, pretende-se mostrar como esses conceitos também revelam formas de ordenar o 
mundo a partir do binômio ver/representar - ou, como pensamos aqui, é o olhar para o elevado e outro, para o humilde.

O Sublime é discussão antiga: encontra-se já em Aristóteles, que o chama de Elevado, e o vê como a forma de representação que busca uma espécie de elevação, tanto na escolha de uma linguagem mais "culta", trabalhada, quanto no enlevo do próprio interlocutor. Também foi discutida a partir de uma concepção de conteúdo ou temática: haveria assuntos mais ou menos elevados, e o discurso sublime, parte da retórica, serviria para assuntos também da mesma lavra. Auerbach (2000), em Ensaios de Literatura Ocidental, faz uma investigação filológica e filosófica dos termos e enfatiza entre outras importantes considerações para a compreensão de tais conceitos, da distinção entre a mera elocução (haveria, dentro da retórica clássica, categorias próprias para cada tipo de enunciação) e uma ampliação semântica e estilística do termo: o crítico apontará o surgimento do cristianismo e a própria figura de Cristo como essenciais para a ampliação do termo Sublime. Sucintamente, as narrativas que envolvem Cristo conteriam demasiado realismo e ele próprio é vítima de humilhações. Na classificação clássica, o estilo que predominaria seria o baixo, quando muito o médio. No entanto, esses elementos irão ampliar a compreensão da possibilidade do estilo Humilde e de uma ressignificação do Sublime:

A história de Cristo contém todos os seus elementos; quanto mais popular se torna, tanto mais seu realismo de origem, intimamente ligado a seu caráter sublime, se desenvolve e floresce. É inegável que se trata de um sublime de lavra inteiramente cristã, suscitado e inspirado pela história de Cristo e pelo 'estilo' da Sagrada Escritura de modo geral.

(AUERBACH, 2000, p. 18)

O estilo Humilde irá percorrer, a partir da Idade Média, um longo percurso de teorização e de aceitação: percebe-se desde a Antiguidade Clássica o cuidado em utilizá-lo, em questões, por exemplo, pecuniárias, quando no espaço jurídico. A partir do que mostra Auerbach, é numa mudança de paradigma de mundo que o estilo Humilde encontrará não somente uma aceitação e um uso ampliado; será uma forma própria de representar o mundo, a partir de uma forma nova de compreender o mundo. Será o mais importante termo utilizado (humilis) para designar a própria Encarnação de Cristo. Seus vários significados ("humilde”, "inculto", "esteticamente tosco") é que o alçará a uma posição de destaque e de mudança de sinal; de um conceito 
negativo tornar-se-á, após principalmente os Pais da Igreja e em particular Santo Agostinho, termo da mais alta lavra: "Nota-se então, especialmente no âmbito moral, a inversão de significados: desaparece o tom pejorativo e ganha relevo o aspecto positivo - fraco e raro na literatura pagã. " (AUERBACH, 2000).

Em se tratando de Cesário, a primeira ideia que surge ao se tratar de tais estilos é a oposição antitética grotesco/sublime, tão difundida em sua época e que se torna um recurso do estilo romântico em geral. Interessa, no entanto, nesta parte, pensar na oposição entre o Humilde e o Sublime, e como o uso de tais modos de ver/representar contribuem para a dimensão do modo de olhar que por ora, especificamente neste recorte, delimitamos. Também interessa discutir como a ordenação e a contraposição entre o olhar para o elevado e o olhar para o humilde, em esquema dialético, abrem novas possibilidades de significação. Ao fazer menção das estruturas poéticas, entende-se que a estrutura do discurso permite, per si, uma apreensão de mundos, no plural: em questão, como Cesário alterna os discursos, de forma sutil, para valorar os sujeitos (mesmo quando se trata do eu - lírico) que são representados no universo poético.

Em um dos seus poemas iniciais, iniciado pelo verso "Num tripúdio de corte rigoroso", já é possível visualizar o uso do discurso sublime em posição antitética ao discurso humilde: aquele transparece na estrutura do soneto petrarquiano, na isometria do decassílabo, no esquema rítmico e principalmente, na escolha do léxico e das figuras de linguagem. Veja-se o par "linfática/simpática" que adjetiva a Vênus grega e escultural: os dois termos podem dizer respeito às características físicas ou psicológicas. O primeiro termo pode ser lido como "algo a que falta vida, vigor, energia (diz-se de indivíduo); apático", ou "na classificação hipocrática dos quatro temperamentos de acordo com o humor dominante, que ou aquele que, pela lividez das carnes, flacidez dos músculos, apatia e debilidade demonstradas no comportamento, atesta a predominância de linfa". Note-se que se trata de um arcaísmo, que empresta um tom inusitado aos versos, e tem sentido semântico disfórico. Tal negatividade ressalta-se em oposição à "simpática", que também alude a um estado de espírito (algo que agrada aos sentidos) ou a características fisiológicas (relação entre corpo e mente que faz com que um seja afetado pelo outro).

Num tripúdio de corte rigoroso,

Eu sei quem descobriu Vênus linfática, 
- Beleza escultural, grega, simpática,

Um tipo peregrino e luminoso. -

O “duplo" sentido (psicológico/fisiológico) dos léxicos no quarteto vão caracterizando a mulher do poema, dando-lhe não só uma corporeidade, mas fazendo deste um resultado do dado psicológico: a dupla acepção da palavra simpática pode ser lida numa clave positiva ou negativa e é sua acepção enquanto ato psicológico que determinará o valor semântico das palavras "Vênus", "Beleza escultural", "grega". Cabe ressaltar que os vocábulos destacados dizem respeito muito mais a características físicas, o que parece se comprovar com o uso do adjetivo "escultural" junto ao substantivo abstrato "Beleza", deixando claro que o olhar avaliativo do eu - lírico é a partir de um distanciamento, imposto pelas atitudes dela. Assim, se por um lado tem-se uma mulher fisicamente apreciável, o “(..) tripúdio de corte rigoroso" revela um tipo de comportamento condenável e um temperamento não menos positivo. Essa compreensão não é imediata: essa mulher ainda é comparada a um tipo "peregrino e luminoso" que parece fazer um espelhamento com o primeiro verso da estrofe seguinte: "Foi lâmpada no mundo cavernoso". A palavra "peregrino" parece se opor às referências clássicas já mencionadas, devido à sua alta carga religiosa. Entretanto, a ideia do mundo das cavernas remete à alegoria da caverna platônica. Essa mulher então se caracteriza a partir tanto do corpo escultural, quanto de uma transcendência positiva: aos olhos do eu - lírico, surge como motivadora da sujeição do amante, vista no final do quarteto:

Foi lâmpada no mundo cavernoso,

Inspiradora foi de carta enfática,

Onde a alma candente mas sem tática,

Se espraiava num canto lacrimoso.

São os dois tercetos que trarão uma oposição não só de léxicos, mas da própria representação do feminino, do homem enganado e do próprio eu, e fará a mudança entre um discurso que se aproxima do sublime na estrutura formalística, na temática (o amor) e se tornará prosaico, confessional e risível. Aristóteles define o Risível como uma desarmonia (é verdade que de pequenas proporções e sem consequências), como um contraste, como um embate. As reflexões que surgirão posteriormente sobre o Risível são profundamente marcadas pela ideia de contraste. Em linhas gerais, Schelling dirá que "um ato humano se torna risível quando o homem, renunciando explícita ou implicitamente à sua condição de ser livre, assume os modos 
mecanizados da natureza" (SUASSUNA, 2004, p. 152). Esse modo mecanizado diz respeito à sujeição a necessidade; na natureza humana, tal necessidade poderia ser exemplificada na “(...) alma candente, mas sem tática" que "Se espraiava num canto lacrimoso", ou seja, o amor descompassado, sem regras, leva o amante ao sofrimento solitário.

Há uma consideração relevante a ser feita: o amante desenganado seria outro ou o próprio eu - lírico? Levando-se em consideração a primeira hipótese, o verso "Eu sei quem descobriu", colocaria o eu - lírico na posição de testemunha, o que permitirá ler os versos finais a partir da consideração de que o eu - lírico, presentifica como testemunha a relação e a descoberta dos subterfúgios, e se distancia pelo uso do pronome oblíquo em oposição a sentido dado pelo uso do pronome reto. Nesse caso, o Risível seria perceptível na categoria da ironia humoresque, que Lélia Duarte (2006) explica como resultado de um “(...) espírito alerta e ativo, capaz de afirmar sua substância nas fronteiras, consciente de que o absoluto se realiza e ao mesmo tempo se destrói num momento fugidio". Dessa perspectiva, os versos finais constroemse numa espécie de afastamento, paradoxalmente marcados pelas interjeições "ó céus" e "ó meu Deus", que poderiam demonstrar uma empatia do eu - lírico com o sujeito enganado. Entretanto, eu - lírico se afasta tanto da mulher quanto do amante (ou de si mesmo) ao usar de frases prontas e de caráter completamente religioso: contrapõe-se à "linfática" dama, de beleza fria (note-se a referência à escultura) e emoções calculadas pelas missivas modelares. Afastase do sujeito em sofrimento (ou do sofrimento em si) ao mostrar consciência do gesto feminino pragmático. As frases prontas também têm um caráter humilde, popular, contrárias ao tom imposto pela construção imagética tanto da mulher e sua comparação com uma beleza clássica, quanto sua aproximação à metafísica platônica.

Dessa forma, os dos primeiros quartetos, com exceção do primeiro verso da primeira estrofe e o último da segunda estrofe, revelam a beleza exemplar da mulher, motivadora de uma aproximação "enfática” (por carta, entenda-se) do sujeito que se mostra apaixonado. O primeiro verso, dentro da estrutura clássica, "resume" o acontecimento ou a temática: assim, já se sabe que será o "tripúdio" o que será discutido. O último verso do quarteto coloca o sujeito em posição "humilhante", numa perspectiva masculina do século XIX. Os dois tercetos esclarecem o tripúdio e também retiram o véu da imagem feminina: o que ela respondia se tratava de palavras protocolares, sem nenhuma "verdade”. Pelo menos, é isso que afirma o eu - lírico. Considerando-se até esse ponto, a temática que poderia ser sugerida como também sublime nos quartetos (o amor, o conflito) se tornaria prosaica e menos “universal”. Tratar-se-ia, então, do 
embate romântico entre um homem e uma mulher, os recursos desta para enganá-lo a partir de um livro que ensinaria modelos de cartas amorosas. A linguagem menos rebuscada e o discurso mais direto, mais próximo do Humilde, o comprovariam. Considere-se, entretanto, uma hipótese de leitura: que o uso do Secretário dos Amantes fosse (como foi) uma prática comum das mulheres do contexto europeu da época, e servisse como uma forma de apoio para as questões amorosas, como o são várias outras práticas amorosas: enviar flores, convidar para jantar, fazer a corte (cada época com seus protocolos e seus hábitos). Qual seria o grande mal, nesse caso? Parece que se trata da ideia de que o verdadeiro amor só se manifestaria a partir de uma pureza, do imaculado, e o uso de modelos de textos seria um engodo, uma forma de modelar emoções por questão de mero "tripúdio".

Estaríamos então, colocados pelo eu - lírico dentro de um caleidoscópio: a cada pontode-vista, a cada volta do texto, novos sentidos vão se criando, impossibilitando uma definição tácita. $\mathrm{O}$ eu, nessa perspectiva, estaria de fato assumindo-se naquela fugacidade chamada ironia: "Essa atitude irônica contesta o inaudito, o original, o sagrado; mostra que nada é terno e duradouro, nenhum juramento é para sempre, o universo não é infinito”. (DUARTE, 2006; p. 33). Ironizando o desapontamento do sujeito (ou o desapontamento em si), mostra a pequenez humana em exigir do outro aquilo que não se pode encontrar em si mesmo: não era o amante aquele que se "espraiava num canto lacrimoso", numa atitude pouco viril? Não foge ele também do quadro de perfeição manifesta pelo desapontamento com o dito roubo de "frases palpitantes? ”. Nova virada do caleidoscópio. O amor então desce do sublime, do universal e torna-se adjacente às relações sociais: essas parecem estar em discussão e em franca crítica. A aspiração ao ideal amoroso parece ser então alvo efêmero, de um mundo em mudança e da impossibilidade da comunicação entre os seres, constituídos a partir de papéis sociais, convenções ideológicas, falas arquivadas. Sob esse novo "virar do caleidoscópio", aquilo que parecia prosaico vai ganhando outra dimensão, buscando a elevação.

Compare-se, para a compreensão da possibilidade do efêmero, do prosaico e do transitório serem temáticas Sublimes, o poema anterior e o poema de escritura posterior, Nevrose. Note-se a forma como o poema é estruturado: temos, em primeiro plano aparente, um eu - lírico mergulhado em lucubrações acerca de seu trabalho poético. Tomamos contato com suas dificuldades em publicar, questões de mercado editorial, até aspectos de sua poética. Também nos é dado a saber seu estado de espírito e suas ações: estas se limitam ao consumo de cigarros e a rasgar uma epopeia "morta"; aquele mostra um inconformismo com o que 
considera uma injustiça (o seu trabalho não ser reconhecido devidamente, como aparentemente julga merecê-lo). É possível inferir pelo recorte do que mostra em relação ao ambiente, que ande pela sua casa, até se sentar à secretária. E que tem uma vizinha tísica, que está em pleno trabalho, provavelmente faminta. Esta segunda "personagem" é descrita em menos versos do que as já mencionadas reflexões do eu - lírico. A estrutura do poema se perfaz de 17 quartetos. São versos alexandrinos, os três primeiros e um sexteto compõem o último. O esquema das rimas é oposto, compostas em grande maioria de rimas ricas e graves e só se repete em um caso (com o final em -ente, que é o mesmo do primeiro esquema):

Eu hoje estou cruel, frenético, exigente;

Nem posso tolerar os livros mais bizarros.

Incrível! Já fumei três maços de cigarros

Consecutivamente.

Mantém-se a chá e pão! Antes entrar na cova.

Esvai-se; e todavia, à tarde, fracamente,

Oiço-a cantarolar uma canção plangente

Duma opereta nova!

O eu - lírico se constrói a partir de um ponto-de-vista que se divide de forma não equilibrada, e a partir de um estilo que, se não elevado ou sublime, também não é o estilo humilde. A temática também parece carecer do sublime: dir-se-ia visto a partir da visão do eu - lírico como mera admoestação deste em relação à vida. O rebuscamento do alexandrino, o esquema rítmico, o cuidado com o "lapidar" das formas, parecem contradizer o prosaísmo do assunto e da forma como este é apresentado. O tom alterna-se entre um esquemático, rígido, de palavras arcaicas, que o eu - lírico utiliza para construir a si e outro tom, mais livre, feita de frases nominais e sentido afetivo explícito: esse tom, o eu - lírico reserva para a tísica. Nessa variação de tons, percebe-se como os dois tipos de discursos, o Sublime e o Humilde, podem representar não só uma escolha estilística, mas também uma maneira de construir um sujeito, a partir de uma perspectiva que, se ideológica, o é na medida que a poesia em si carrega suas próprias "ideias". No caso, notamos que o uso de um discurso mais culto, para falar de si e de 
seus problemas, se mostra uma forma de valorizar-se, de construir-se pelas palavras de forma mais destacada.

Em Cesário, como já alertado, deve-se cuidar que os elementos da poesia são revelados por um eu - lírico, que nesse processo, também se revela: vimos que se trata de um escritor, às voltas com a não-aceitação do público, com as questões de publicação, de "manobras" (entendidas como atitudes ardilosas) necessárias para sua aceitação. Também revela de forma explícita o contexto social e o contexto do mercado editorial: por essas expressões, situamos o eu - lírico em um espaço social e um tempo histórico específicos. Compreendemos sua "profissão" e as questões que a envolvem. Nessas questões, estão dados de sua poética, que coincidem com a estrutura do próprio poema (o itálico quer chamar a atenção para ideia da simultaneidade e não do acaso):

Que mau humor! Rasguei uma epopéia morta

No fundo da gaveta. O que produz o estudo?

Mais duma redação, das que elogiam tudo, Me tem fechado a porta.

A adulação repugna aos sentimentos finos;

Eu raramente falo aos nossos literatos,

E apuro-me em lançar originais e exatos, Os meus alexandrinos...

Enquanto se mostra inconformado com o que considera uma injustiça (a não publicação de seus versos), com deformidades sociais (a ausência de cultura para a compreensão da sua obra, a necessidade de adulação, etc.) e vai se enervando consigo, descreve sua vizinha de uma forma que parece "ocasional". Esta vizinha, assim como um quarteto em que aparece referência ao povo ("Soluça um sol-e-dó. Chuvisca. O populacho/Diverte-se na lama), incitam no sujeito imagens menos graves do que a maioria dos versos que tratam de si e das questões do mercado editorial irá merecer. Não se engane, no entanto: o sujeito não irá alterar-se ou fazer qualquer reflexão sobre questões de mundo. Cabe ao leitor, adentrar na cena criada, e perceber por si: 
Uma infeliz, sem peito, os dois pulmões doentes;

Sofre de faltas de ar, morreram-lhe os parentes

E engoma para fora.

Pobre esqueleto branco entre as nevadas roupas!

Tão lívida! O doutor deixou-a. Mortifica.

Lidando sempre! E deve conta na botica!

Mal ganha para sopas...

Ao falar de si, mesmo com o uso de frases nominais e interjeições, o eu - lírico não enternece o leitor: o uso de descrições abundantes, de palavras inusitadas, de construções sintáticas complexas, e principalmente, da própria situação mostrada, não permite o enlevo. $\mathrm{O}$ que acontece é situação que se assemelha ao poema anterior: a ironia humoresque é inferida pelo próprio texto, já que, em contraposição aos seus males, o da vizinha é infinitamente maior. Mas isso numa perspectiva ampla: o eu - lírica mostra de si aquilo que vê, reduzindo sua consciência. E mostra o que vê a partir da consciência que tem de si e através de um véu que explicitamente constrói a partir de sua caracterização: pelos elementos citadinos, pelas referências culturais, pelas questões da sua própria profissão, percebemos a mentalidade burguesa em sua acepção mais "esquemática".

Assim, no poema em questão, tal qual um drama moderno, o leitor enquanto espectador teria em segundo plano as lidas da vizinha doente. E nesse plano, ao mostrá-lo, o discurso utilizado é o Humilde, mas a caracterização da mulher é sublimada. No verso "Pobre esqueleto branco entre as nevadas roupas!/ Tão lívida!”, algumas das características do estilo de Cesário surge para "embelezar" o feio, ou sublimar aquele quadro humilde: o uso de referências cromáticas, no caso a cor branca, os adjetivos "nevadas" e "lívida", cria um contraste com o próprio eu e o espaço em que circula. Aliás, há duas referências a fumaça, que poderia ser lida como uma metonímia caracterizadora de ambos. A fumaça dos "três maços de cigarro", fumados de forma consecutivas, mostrando os vícios do eu, é dicotomizada com a fumaça do "ferro aceso", que a asfixia:

E a tísica? Fechada, e com o ferro aceso!

Ignora que a asfixia a combustão das brasas,

Não foge do estendal que lhe umedece as casas,

E fina-se ao desprezo! 
Viremos a primeira volta do caleidoscópio: um eu que se caracteriza como um burguês típico e sua mentalidade egótica e hedonista, em primeiro plano; uma mulher pobre, doente, abandonada, trabalhando até tarde, em segundo plano. A oposição entre os comportamentos de ambos, destacadas pela ação produtiva: ele, produzindo arte. Ela, limpando e engomando. Ele, pela não aceitação do seu trabalho e pela vontade do ganho financeiro sobre ele (a referência ao dinheiro se faz duas vezes de forma explícita), mostra-se inquieto. Não é essa inquietação, no entanto, produtiva em si: ao invés de escrever, ele imagina as mencionadas manobras; sonha, enriquecido, mudar-se e ver impressa sua obra. Ela cantarola enquanto trabalha. Pode-se imaginar que toda a ação, dada em um estilo médio, alterando para o Humilde quando se trata de mostrar a vizinha, serve para a discussão dos males da sociedade burguesa em diversas direções: aqui, apontamos apenas algumas, considerando a intenção inicial. Mostra-se, nesse olhar, a condição de sujeição do ser humano, o isolamento em especialidades, a engrenagem mercantil que a tudo e a todos devora.

Dada a segunda volta, vemos que a temática e a caracterização extremamente realista servem como contraponto a algumas inquietações: a visão do mundo do sujeito apresentado não é limitada aos seus próprios interesses e a sua própria ideia de mundo? Não seria essa uma forma de visão social e a representação não seria mera explicitação do valor que o outro tem, ainda mais se tratando de uma vizinha tísica, "feia" e abandonada, em plena efervescência industrial europeia? O sujeito isolado de tudo e todos tem alguns instantes de vitória ao imaginar-se não-ali ("e noutros climas") e não mais o mesmo: nesse caso, ele imagina-se "rico" e "publicado", e na própria ordem dos fatores, a mentalidade de si e da época transparece: rico, poderia publicar e não a publicação o tornaria rico. Rico, como objetivo final, não teria como vizinha uma tísica, e o mundo, pessoal e construído, poderia ser intocado pelos males do mundo social e aparentemente sem lógica ou justiça.

Dessa forma, poderíamos pensar que, se no primeiro poema o Sublime aparece de forma fugaz, ainda ligado a questões de discussões de ideias e modos de ser-no-mundo, aqui, os versos finais revelam um Sublime mais intenso, pois se trata de uma condição mais próxima do mundo que o poeta apresenta: somos todos, no final das contas, sujeitos somente de nossas representações, isolados e sem leitores, isolados pela máquina que o mundo construído pelas próprias mãos humanas se tornou. Do escritor e a engomadeira, ambos sujeitados pela aparência (ele construindo seus alexandrinos; ela passando roupas de outros), a poesia surpreende um 
instante de compreensão do mundo, quando o eu - lírico se abandona nos versos finais, de forma Humilde, construindo uma nova engomadeira: Sublime naquilo que o universo representado pode ter, isto é, momentos de existência fugazes. Como apontaria posteriormente Pessoa, aludido na epigrafe, ao colocar o mundo de maneira a espelhar as antíteses, a poesia ainda seria a possibilidade fugaz, que também em si se esvai, da tentativa da permanência das coisas.

E estou melhor; passou-me a cólera. E a vizinha?

A pobre engomadeira ir-se-á deitar sem ceia?

Vejo-lhe luz no quarto. Inda trabalha. É feia...

Que mundo! Coitadinha!

\section{Um olho no aqui-agora e outro no acolá-então}

A técnica de concentrar o olhar em determinado aspecto do mundo - e dele descobrir e distender inusitados "segredos" e significados - captaria, quer indiretamente, quer diretamente, caso este que tratamos a partir de agora, da percepção da efemeridade do tempo. Como nos estudos anteriores, aqui também o olhar é duplo, isto é, se constituí a partir da dicotomia, para avançar em direção as sínteses que o poema pode pretender acolher, captar ou guardar em si. O duplo se dá pela oposição que delimita o tempo e o espaço: daí o aqui-agora e o acolá-então. As duas oposições se constituem dialeticamente, assim como pensamos o encanto e o desassossego, e o elevado e o humilde, isto é, a concepção e a percepção de um par, pressupõe a percepção e a concepção do outro. Falar do agora é, por consequência, implicar o antes e o devir; assim, também se compreende o falar do aqui, que tem implícita em sua constituição, ou não-aqui: o lá e o acolá. A diferença, tecnicamente explicando é que o lá diz respeito a $2^{\mathrm{a}}$ pessoa do discurso, enquanto o acolá fala da terceira. Para efeitos semânticos, o acolá suscita um distanciamento ainda maior dos sujeitos.

Diferentemente do que fizemos anteriormente, abrindo e exemplificando determinada questão da poética/mundividência em mais poemas, neste ponto, por entendermos ele ser o mais facilmente reconhecível e mais amplamente discutido da obra de Cesário, nos restringiremos a um único caso. Entendemos, inclusive que não é o caso mais exemplar ou em que há mais clareza de tal oposição de olhar, mas é aquele em que especificamente, a diluição, a síntese 
desse olhar, o que está aqui-agora e o que está acolá-então, cria algumas importantes proposições sobre a visão de mundo verdiana. Tais proposições, ressalta-se, permeiam a obra em um todo, o que nos permite dizer, sem prejuízo crítico, que Num Bairro Moderno é a síntese artística e por consequência, um momento de reflexão ontológica, do que seria o mundo ideal em que a arte e o mundo em si coexistissem temporalmente e espacialmente. Sinteticamente, a função da arte, do artista, as musas e temáticas, e, principalmente, como poderia existir em uma situação real, um Cesário idealizado por ele mesmo. Ainda mais resumidamente, utilizando somente o efeito principal buscado e conseguido nesse poema, a felicidade do amor sem fim. Entenda-se fim como finalidade, como final temporal e como término.

Olhar a cisão entre passado e futuro e, por consequência, o aqui e o lugar distante, está tão presente na obra de Cesário, que raras serão as ocasiões em que tal condição não se mostra: uma delas, que discutiremos adiante, está no poema Provincianas, e é coerente, pelo menos para nós, que não haja neste poema tal cisão. Também lembramos que a própria constituição do gênero lírico é, em si, a constituição desse estado de separação entre sujeito que fala de si e aquilo que viu, sentiu ou pensou. Lembramos, pois seria possível dizer que não é um elemento central em Cesário e sim um "acidente" do gênero que preferencialmente utiliza: em outras palavras, a escolha do gênero lírico implica, não necessariamente de forma direta, em colocar o passado distante do eu-poemático. Pensamos que, exatamente para que a percepção de tempos se dê de forma clara, explícita e sensível é que o poeta não se contenta com as questões inerentes ao gênero literário e dá o passo além: coloca muitas vezes o tom narrativo, instaurando outra temporalidade dentro do poema. A narrativa tem o efeito de presentificar a ação e assim, também, empresta tal efeito para aquilo que o sujeito narrado ou aquilo que se narra diz pensar, sentir ou perceber. É o que veremos em Num Bairro Moderno. Nesta na percepção de uma cisão entre o passado e o presente, o aqui e o "acolá", a principal dialética e constatação sobre o mundo que percebemos na obra de Cesário. A passagem do tempo e a efemeridade das coisas leva a um desejo de captação, preservação e revalorização daquilo que não mais se possui ou daquilo que então não se percebia. Assim como procede nas situações que anteriormente mostramos, o seu olhar atua, primeiramente, por um processo de descobrir e desvelar inusitados significados e sentidos.

Dez horas da manhã; os transparentes

Matizam uma casa apalaçada;

Pelos jardins estancam-se os nascentes, 
E fere a vista, com brancuras quentes,

A larga rua macadamizada.

Rez de chausée repousam sossegados,

Abriram-se, nalguns, as persianas,

E dum ou doutro, em quartos estucados,

Ou entre a rama dos papéis pintados,

Reluzem, num almoço, as porcelanas.

Como é saudável ter o seu conchego,

E a sua vida fácil! Eu descia,

Sem muita pressa, para o meu emprego,

Aonde agora quase sempre chego

Com as tonturas duma apoplexia

(Num Bairro Moderno)

O poema "Num Bairro Moderno" é, para nossa leitura, fundamental para a compreensão do olhar que está centrado no aqui-agora e outro que busca o lá-então. Note-se que já no título somos, leitores, colocados em um determinado espaço adjetivado por uma palavra que possui também semântica temporal. A contração da preposição com o artigo indefinido "um", pela sonoridade e pela condição do uso coloquial, expressa desde o título, algumas características deste espaço: ele é comum (daí o um) neste contexto histórico e a maneira de "dizê-lo" (num), reforça por um lado esse aspecto e por outro, tendo em mente a diferença sonora e de pronúncia entre a opção mais "culta" - em um - a oralidade e a "velocidade", já que a leitura de "num" é notadamente mais acelerada do que "em um". Cabe também destacar como a preposição delimita o espaço (e como veremos, o tempo neste espaço) e nos orienta a olhar por dentro e não por fora, o tal bairro. Este posicionamento não é gratuito: ao delimitar o espaço em um bairro, paradoxalmente, o nosso olhar se concentra nas características específicas de tal lugar. A origem etimológica da palavra bairro viria do árabe barri, e significaria "exterior, arrabalde, próprio dos arredores de uma cidade". A partir desse conceito etimológico para a denominação deste espaço topográfico, o próprio espaço do poema torna-se também mais claro e substancialmente mais polêmico: o bairro é ainda uma parte e não o todo da cidade representada no poema. A observação do sujeito e a caracterização espacial ao deter-se especificamente em 
tal organização da cidade é relevante. Também é, como a mesma fonte explica, o conceito de bairro propriamente dito, ou seja, uma organização urbana no qual as edificações seguem um único projeto e é uma das heranças da Revolução Industrial, pela necessidade de acomodar os operários das fábricas. Em Portugal, anterior a Revolução, algumas habitações foram construídas com uma certa ordem, formando pequenos aglomerados urbanos dentro da cidade (os exemplos são os bairros históricos de Alfama ou o Bairro Alto).

Nesta delimitação específica, algumas características presentes na obra de Cesário surgem. Uma delas, a observação da dita modernidade em contraponto ao tradicional, quer se utilizando da descrição destes elementos modernos e também dos elementos da tradição, estão, em regra, em conflito. Entretanto, ao mostrar tais oposições, temos o quadro da própria passagem, neste caso, histórica, do Tempo. E é a maneira que mostra, ao colocar a modernidade e a tradição no poema, em embate, que nos desperta a percepção de uma espécie de contração temporal, isto é, os séculos que caracterizariam cada um dos momentos e também os séculos em que há esse movimento de embate, diluem-se. Percebemos, no embate - ao metonimizar a tradição e a modernidade (quer pelos objetos, quer pela vestimenta, quer pela descrição espacial), mas também pela concentração do olhar nos elementos efêmeros - os séculos "acelerando-se" (isto é, os que os caracterizou) e os valores passando de maneira abrupta. O bairro (de origem antiga, mas que também vai se transformando) é agora, pelo olhar de um sujeito que não pode ver a História "de fora" e sim a sua consequência de dentro, moderno.

E é exatamente este movimento, do olhar que percorre as coisas, que a primeira parte do poema, a caminhada do sujeito para o trabalho, se destaca. Tal maneira de olhar e o que olha, se condiciona, como se percebe, pela primeira frase do poema: “Dez horas da manhã;(...)”. Chamamos frase pois consideramos que a pontuação cria uma independência sintática em relação ao restante, mantendo, no entanto, uma ligação semântica e, principalmente, pela ausência de verbo. Esta ausência cria um curioso efeito: a notação temporal não é agente nem paciente de qualquer ação, mas a coisa por si mesma. Se a independência sintática reforça a percepção de tal hora como algo que exista per si, não se pode deixar de notar que tal marcação é humana, isto é, uma forma e uma métrica formalizada pela sociedade (a partir da observação da natureza e de uma certa regularidade desta, diga-se) para uma tentativa de controle do tempo.

No mínimo, é curioso que se inicie um poema destacando de tal forma o poema. Mas, se em algum momento não só a Natureza possibilitou tal ordenação do mundo, como também 
o engenho humano o calculou e construiu uma "régua", não seria de se espantar que toda esta estrofe, bem como a seguinte, careça (ou dispense) de qualquer ação humana para que as ações aconteçam? Ou melhor formulando tal afirmação: notamos que os agentes das ações (algumas vezes também os pacientes), bem como o uso da indeterminação do sujeito, provoca uma espécie de teatro onde os próprios objetos se organizam, causam efeitos, movem-se numa espécie de personificação. Daí, que o uso da antropomorfização que permeia as duas primeiras estrofes, incita uma circularidade: o homem construiu tais objetos (entre eles a medição temporal tão acurada), mas, de alguma forma, os objetos, pelas suas funções originais (uma cadeira serve para sentar, o vidro para proteger, a louça para se comer) não necessitam de qualquer ação humana para se impor. De "senhor das coisas", o homem construtor torna-se condicionado por elas. Do observador que fez o relógio, é este que o faz agora agir.

Usamos a expressão "teatro" anteriormente, pois a personificação sugere movimento, mas pela maneira de descrever a tal casa apalaçada e suas características, além dos objetos que ali estão, também poderíamos chamar de pintura. Feita de palavras, como já amplamente discutido (e que discutiremos em outra perspectiva com mais detalhes posteriormente) pela crítica estabelecida, esta visualidade dentro da poesia reforça o aspecto artístico de uma cena aparentemente cotidiana. O olhar que o capta, o faz (e assim também o constrói) em um ritmo pausado (como a cesura, criada principalmente pelas vírgulas) sugere. Os enjambements presentes no primeiro e no quinto verso, separando o sujeito do verbo, além do já apontado uso da pontuação, criam um ritmo dilatado (sonoramente, pelo andamento rítmico) que sugerem uma certa harmonia por um lado e prendem o olhar nestas visões por outro. Esta cena doméstica e seus apetrechos prendem a atenção, por um considerável tempo, do sujeito poético. E é considerável o esforço em transformar algo aparentemente sem importância em uma visão artística.

A terceira estrofe, após tal fruição, toda construída com elementos narrativos, abruptamente nos orienta para a interioridade do sujeito que fez tais observações, ou seja, para os elementos próprios da lírica, nesta também moderna diluição dos gêneros poéticos. Dizemos também pois é inegável que aquele olhar artístico e regente da harmonia das coisas estilizou uma casa da época Moderna. A estilização presente em tais trechos, ao mesmo tempo que, artisticamente provoca a percepção e o afeto, pode colocar em segundo plano as questões históricas e sociais. Ou, como nos parece, transforma História e Sociedade em Arte. Antes de adentrarmos neste elemento, que merecerá um olhar mais atento no último capítulo, pensemos 
no efeito da passagem dos elementos épicos (ou narrativos, como já dito) para os elementos líricos, pois constitui uma das notáveis características da poética cesárica. Neste poema, em especial, após o que mostramos nas duas primeiras estrofes, temos a observação (valorativa) daquilo que foi poetizado anteriormente, pois o foco concentra-se na interioridade do eu; primeiramente nas suas impressões, de forma implícita e, depois, de forma explícita no uso do pronome "eu”: "Como é saudável ter o seu conchego, /E a sua vida fácil! Eu descia, / Sem muita pressa, para o meu emprego, (...)". Entretanto, é importante perceber que o uso do pronome possessivo na terceira pessoa, por duas ocasiões neste trecho, demarcam a separação entre o poeta e o objeto poetizado em termos de "propriedade" (utilizando um conceito proudhoniano, a quem Cesário conhecia bem a obra). O gesto artístico, que apreende tal propriedade, torna-se, enquanto arte, "posse", isto é, de forma sintetizada, um bem comum a todos.

A demarcação do momento épico do lírico, sendo o primeiro a casa transformada em arte, não pertencente ao sujeito, e o segundo, as suas impressões e valorações em torno dela, ou, como aventamos, a casa Moderna, burguesa, sem a presença humana, representando a propriedade e todas as implicações sociais ou legais que desse termo possa se dizer, irá, adiante, mas não de imediato, mostrar uma outra valoração e um outro objeto a ser estilizado: as verduras da verdureira. Porque, neste momento, após o idílio artístico e a impressão aparentemente elogiosa de tal espaço, o eu-poemático, nesta estrofe, ainda se divide entre aquela cena e a sua própria condição. Note-se que a mesma cadência das duas estrofes é dada aos três primeiros versos da estrofe seguinte, mas nos dois últimos versos, a pontuação que impunha tal ritmo desaparece completamente, como se o ritmo se acelerasse: “Aonde agora quase sempre chego/ Com as tonturas duma apoplexia". O enjambement neste caso, não só acentua tal aceleração, como destaca, com o verso subsequente, a maneira como tal sujeito chega: depois da cena "saudável", a constatação da doença. Após o ritmo aprazível e lento, dos versos anteriores, a aceleração. E, concentrando-se na questão da noção de efemeridade, a determinação temporal - que na primeira estrofe também deve ser vista a partir da perspectiva semântica e pragmática, ou seja, o horário do despertar da cidade e a posição do sol no céu (fato que o mesmo poema irá explorar), dentro da ideia da sucessão temporal e do movimento da Natureza - congela-se ou mostra uma espécie de prisão do sujeito na palavra "sempre". É importante lembrar que esta palavra pode tanto ser um substantivo quanto um advérbio (é um advérbio neste caso, alterado pelo outro advérbio "quase") e a noção de algo que se repita de maneira ininterrupta, constantemente, liga-se ao estado do sujeito e a sua ação (o chegar ao trabalho). Também há outro advérbio, "agora", que produz um efeito importante: a presentificação de tal ação. 
Novamente, não só acompanhamos o que vê o sujeito, mas a presentificação nos "coloca" dentro das cenas. Essa contraposição, que por vezes mostra uma justaposição entre a lírica e a épica, o olhar para fora e o olhar para dentro, o tempo em compasso vagaroso e o aceleramento não são exclusivos deste poema, mas permeiam uma substancial parte da obra poética de Cesário.

A quarta estrofe inicia-se em um tom coloquial pela copulativa "E", contrapondo-se ao utilizado nas duas primeiras para descrever a beleza da casa, dos móveis, da louça. O tom é tão coloquial que se inicia pelos adjetivos antes mesmo do substantivo, rompendo com a ordem direta prevista na Norma Culta e compondo o "quadro" da verdureira por partes: neste particular caso, contrariamente ao começo do poema (e vale lembrar, às mulheres que o encantam em outros poemas) a descrição mais "humilha" do que "eleva": "rota, pequenina, azafamada". A quarta e quinta estrofe fazem um contraponto às duas primeiras do poema: lá, a beleza é moderna, refinada, ordenada e desumanizada; aqui, há um ser humano, mas descrito com características que fogem aos padrões de beleza, completamente atarefada. Mas lá e cá, temos um elemento em comum: o sol. O mesmo sol que matiza e cria um encanto à cena da bela casa, parece castigar e iluminar de forma indevida à feiura que raramente é pintada ou percebida. $\mathrm{O}$ mesmo sol que fornecerá a luz para que o empregado doente se revele, no fundo, um artista e transforme todo o universo até aqui mostrado. Mas o que acontece entre esse momento e a cena da verdureira?

A quinta estrofe repete um esquema utilizado em Humilhações: coloca outras personagens interagindo de forma a uma constranger ou subjugar a outra. No caso do poema citado, o municipal constrange o sujeito, que também se sente assim com a pedinte. Esses vários quadros compõe um maior, como uma narrativa que se faz de pequenas, mas interligadas e conectadas pelo espaço/tempo em que estão. Não se trata somente de ações, mas ações que caracterizam, e assim são utilizadas, o espaço/tempo do poema. Utilizando um vocabulário mais técnico, o espaço social e o tempo social ganham emprestadas características por alusão às ações e os atores. Cesário, no entanto, não deixa de caracterizar o espaço, nem os atores, nem as ações, concentrando-se em cada um dos elementos. De qualquer forma, os quadros que cada personagem compõe tem independência semântica e sintática, mas, em relação, ganham novas perspectivas. $\mathrm{O}$ criado que, do alto de alguma casa, joga o dinheiro em direção à mulher, não difere tanto do sujeito e sua primeira impressão da mulher. O desprezo é o mesmo: do criado com o gesto concreto; dele, com a forma como vê e retrata a mulher. O som da moeda batendo 
nas frutas, no entanto, o desperta para outra realidade. Antes, havia dois espaços/tempos: o do sujeito e do criado - que são típicos indivíduos do que representa a casa apalaçada - a modernidade urbana higienizada, estilizada, mas desumana, em contraposição ao outro espaço, o da verdureira, o espaço do acolá e, por consequência, do então.

Do patamar responde-lhe um criado:

"Se te convém, despacha; não converses.

Eu não dou mais." E muito descansado,

Atira um cobre lívido, oxidado,

Que vem bater nas faces duns alperces.

É na sexta estrofe que há uma mudança tão radical, que precisaremos pontuar, para dar conta de abarcar a importância dela no poema e na obra como um todo do poeta. A primeira palavra, devidamente ressaltada pelo uso posterior a ela do hífen, é da classe gramatical dos advérbios: e a quantos melhores e mais cuidadosos críticos e leitores não se fixou o uso dos advérbios em Cesário como marca estilística, pela profusão e pela forma muito pessoal de utilização? Mesmo que o restringíssemos ao campo semântico, notaríamos a quantidade acima do uso corriqueiro e natural para modificar e qualificar modos e tempos, principalmente. Em casos, como o "subitamente" nos mostra, ele exerce uma dupla função: de explicitar o modo sem ser previsto, subitâneo, repentino, inesperado-, mas também por aludir a uma marcação temporal na ação, já que se utiliza "súbito" em geral com a conjunção "quando", que se lê implícita na frase. Assim, de forma imprevista, repentina, o sujeito é tomado por uma "visão de artista! "e, graças a essa visão, é-lhe dado o poder da transfiguração e da animização, e mais importante, da transformação da humilhação em amor. A transfiguração está em sua dupla acepção: da mudança das formas das coisas, dando-lhe outra feição e também da forma como percebe ou sente. Auxiliando e dando-lhe as tintas, enquanto intertexto e fundamentação estilística (e ideológica), o sol, o "intenso colorista."

Subitamente - que visão de artista! -

Se eu transformasse os simples vegetais,

A luz do sol, o intenso colorista

Num ser humano que se mova e exista

Cheio de belas proporções carnais?! 
O sol e seu efeito de passagem de tempo são temáticas e posicionamentos utilizados tanto pelos impressionistas, principalmente pelos estudos em torno da luz no mesmo objeto ou espaço, com os jardins, e isso não é desinteressante ou desconhecido para Cesário Verde. Neste trecho, no entanto, além da referência a essa técnica, também temos a referência a arte do artista italiano Arcimboldo, especificamente na série “As quatro estações” de 1573. Nesta série, muito conhecida, o artista realiza uma antropomorfização de elementos da natureza, compondo um rosto humano, híbrido com um rosto animal. Uma vez se estabeleça pelo intertexto a "empunhadura" do seu pincel, traça também o objetivo: que a arte faça dos vegetais, daquilo que é insuspeito, indiferente e cotidiano, um ser humano que "se mova" e "exista/Cheio de belas proporções carnais(...)". Nesta pequena condensação, voltamos a pontos anteriormente discutidos: a necessidade de ação (e servir a algum propósito - a utilidade), o "se mova", ligada a própria existência, condicionando ambas as ações à coexistência; e a existência como modo de imantação ou experimentação da beleza. Ela, neste caso, é cheia de "belas proporções carnais", física e sólida, complementando a existência dada pela ação. Cabe, antes de avançarmos, destacar duas poéticas distantes no tempo e espaço, como o Maneirismo e o Impressionismo sendo aludidos na mesma estrofe: dizíamos anteriormente que o olhar de Cesário "opera" ou percebe polos como maneira de sintetizar ideias, valores e formas artísticas, quer à nível lexical, quer na superestrutura (como é o caso, por exemplo, de diálogos entre poemas ou entre gêneros literários), como uma questão poética que expressa uma visão de mundo. Se dissemos e retomamos, é para a percepção, caso a caso, de como a recorrência, a retomada ou uma novidade ou excrecência, demonstram a dinamicidade da arte e, no caso do poeta aqui estudado, como a dinamicidade em si, da impossibilidade da definição única do que quer que seja, cria o efeito de efemeridade conceitual e sensorial.

Bóiam aromas, fumos de cozinha;

Com o cabaz às costas, e vergando,

Sobem padeiros, claros de farinha;

E às portas, uma ou outra campainha

Toca, frenética, de vez em quando.

Tomado pelo ímpeto artístico, reconciliador e transformador, o sujeito, investido de um novo olhar, está agora sensível a tudo e todos: e a tudo e todos, eleva com o seu pincel. Notese que o olhar nesta situação é tão ampliado que passamos a um estado sinestésico contrário ao da única referenciação visual nas duas primeiras estrofes, já que não temos explicitamente a 
referência a outros sentidos além dela; pelo contrário, o "estancam-se as nascentes" e os "repousam sossegados" é uma visão que desperta também a ideia de silêncio e de inatividade dos objetos(apesar de algum sujeito indeterminado - sintaticamente inclusive - ter belamente arrumado a casa), sem aludir ao sentido da audição. A sinestesia neste caso, além de “demonstrar" a maior abertura do sujeito, antes restrito à visão o coloca na cena, integralmente, e potencializa, para o leitor, as sensações, elevando-as. Este elevar não é estilístico somente, mas sensorial: é tão provocativa, pela percepção de belezas inusitadas, "secretas", e tão sensível, pela arquitetura estilística empregada, que a cena se presentifica pela simpatia e pela sensibilidade. Como não se sentir simpático e sensível aos padeiros, "claros de farinha", se na mesma estrofe entendemos o seu papel social e suas dificuldades?

A estrofe seguinte transparece outro elemento já mostrado: campos distintos do artístico, como a ciência, a religião, o comércio, com seus "afazeres", competências próprias e linguagem técnica especifica, incorporados ao poema. No caso, a anatomia e a pintura, síncronos, realizam a transfiguração e a animização das verduras, instrumentos de um sujeito que, no entanto, ao contrário de se sentir um flaneur distante ou um esteta racional e traçador de ângulos, se comporta como um demiurgo enamorado da sua obra. Ela, como veremos, não é somente a transformação da cesta em um ser humano, isto é, do elemento menos inusitado e humilde, em algo elevado e perene, como é a arte: é a transformação do sujeito, principalmente, em observador da beleza burguesa para coparticipante de uma cidade mais plural e humana do que os pratos e quartos da casa do bairro moderno. A ação do sujeito é, por assim, dizer, a síntese entre o aqui-agora da modernidade sem freios e da avassaladora onda que é a moda e os valores Modernos enquanto vozes ideológicas sedutoras, e o acolá-então, a antiga Lisboa, o velho Portugal agrícola, “feio", mas vivo e pulsante.

E eu recompunha, por anatomia, Um novo corpo orgânico, aos bocados. Achava os tons e as formas. Descobria Uma cabeça numa melancia, E nuns repolhos seios injetados.

Nos versos seguintes, de maneira lenta, cuidadosa, observando com cuidado cada fruta, cada vegetal, cada verdura, cada produto da cesta, vai, por analogia, dando corpo ao seu ser novo, que, com "pernas de gigante" e seios, parece não ter gênero definido, como alguns mitos, 
entre eles a da origem das almas em Patão, que posteriormente eram separadas. Em si, a não identidade de gênero, pelo dito no poema, criaria um ser completo, perfeito e autossuficiente. Importa ainda verificar que o efeito que consegue ao detalhar cada parte do ser em relação a algum elemento orgânico é de contemplação pura, já que o ritmo do poema se desacelera e, com uso amplo de verbos no tempo presente, temos como que a visão de um artista que, lentamente vai colocando as imagens na tela e surpreende a audiência com o resultado inesperado. Essa contemplação pura também suspense a distância entre leitor e obra, ou ainda, entre leitor e a sensação/imagem do eu-lírico. O acolá-então da visão do poeta transforma-se no aqui-agora da sensação/percepção/imaginação do leitor. Por isso, se de fato estamos "na obra", o efeito de sentido não será meramente intelectual, lógico ou estético, mas, porque assim o poeta o construiu, sensorial e de empatia com o que se mostra. Com essa empatia, nos é estranhamente prazeroso o gesto que se segue. Note que colocamos prazeroso e não belo ou bom, para qualificar a ajuda dada a verdureira nas duas próximas estrofes:

\footnotetext{
Eu acerquei-me dela, sem desprezo;

E, pelas duas asas a quebrar,

Nós levantamos todo aquele peso

Que ao chão de pedra resistia preso,

Com um enorme esforço muscular.

"Muito obrigada! Deus lhe dê saúde!"

E recebi, naquela despedida,

As forças, a alegria, a plenitude,

Que brotam dum excesso de virtude

Ou duma digestão desconhecida.
}

A ajuda em si seria, em quaisquer circunstancias, um gesto delicado, talvez virtuoso, em muitos casos uma mera convencionalidade. No poema, ele é a síntese de dois movimentos antitéticos (além do que falamos nesta seção): do artista e da arte como pensa Cesário, com a verdureira e a vida. A arte pode ser estéril (duas primeiras estrofes), realizada por artistas distantes da vida (inúmeros exemplos, mas o de Nevroses é um típico), fechada em si e auto justificável - ou a arte pela arte. Pode pretender ser também a arte das coisas grandiosas, eternas, profundas - ocasionalmente abordada - ou instrumento revelador do segredo das coisas. Tais segredos não se limitam à percepção da beleza no Humilde ou no passageiro, mas que a beleza 
que deles emana (ou que pode de tudo emanar), está ligado a muitas ações concretas de amor. Como não iremos nesta seção aprofundar tal tópico, fiquemos com o mais evidente na presente situação, para que a explicação se torne menos confusa e menos especulativa. O sujeito, interpelado pela verdureira, faz questão de dizer, "sem desprezo", aproxima-se dela e a ajuda a levantar o cesto sobre sua cabeça, recebendo um agradecimento e uma pequena benção. Não demonstra até então, qualquer simpatia por ela, ajudando-a pelo sentido de dever. Esse amor está discutido na philia aristotélica ou no amor ágape kiekegaardiano:

Kierkegaard ilustra o caráter exigente do amor fazendo alusão ao relato no qual Cristo exorta a um anfitrião a convidar para a sua festa não os seus familiares e amigos importantes, mas os cegos, aleijados e desprezados da sociedade. Tal atitude requereria o exercício de um amor não marcado pela predileção e pela afeição, pois o convite seria feito a pessoas bem pouco desejáveis. Neste contexto, entra em cena a seriedade do amor-dever. Tais pessoas não possuíam nada digno de ser amado. Não há prazer em amar o desprezível, mas é dever do cristão amá-lo mesmo assim, diria o pensador dinamarquês. Entretanto, com um objeto não amável só é possível relacionar-se amorosamente por meio de um amor gracioso, dadivoso e desprovido de qualquer atitude interesseira. Eis a exata dimensão do ágape na compreensão kierkegaardiana. (MARQUES, 2016)

O amor-dever, no entanto, se ampliará para o gosto: daí que temos todo um quadro de canários, meninos e das pessoas comuns nesta cidade sendo mostrada de maneira bela. No caso do poeta, há também uma "digestão" desconhecida ao receber as palavras da verdureira: o sentir-se bem (resultado da digestão) não somente fisicamente, mas espiritualmente. O sujeito apoplético está agora em seu auge. E dessa posição que todos os seus sentidos captam essa Lisboa plural e o tempo plural. Cheio desse amor dado e recebido, o seu pincel é generoso, edificador (eleva a tudo e a todos) e esforça-se por transmitir e corporificar na arte a experiência sentida. Estamos, se simpáticos à obra, na Lisboa ideal: há amor e beleza em tudo. É exatamente essa empatia que faz com que a partir dos versos abaixo, percorremos com o olhar do artista sentindo o mesmo deleite por esse momento único:

E enquanto sigo para o lado oposto,

E ao longe rodam umas carruagens,

A pobre, afasta-se, ao calor de agosto,

Descolorida nas maçãs do rosto, 
E sem quadris na saia de ramagens.

Um pequerrucho rega a trepadeira

Duma janela azul; e, com o ralo

Do regador, parece que joeira

Ou que borrifa estrelas; e a poeira

Que eleva nuvens alvas a incensá-lo.

Chegam do gigo emanações sadias,

Ouço um canário - que infantil chilrada!

Lidam ménages entre as gelosias,

E o sol estende, pelas frontarias,

Seus raios de laranja destilada.

As duas últimas estrofes, como que a ressaltar o agora das coisas e perceber nelas a concretização de histórias pessoais, valores, da própria História em si, limitam-se a utilizar um único verbo para cada ator da ação, o poeta, a verdureira, o novo ser, carregando nos detalhes da caracterização, principalmente pelos adjetivos, como que congelando essa cena final, cotidiana e comum, sem aparente grande acontecimento para olhares incautos. Não há mais a efemeridade das coisas e do tempo. O aqui-agora do leitor é o aqui-agora da sensação experimentada pelo autor. $\mathrm{O}$ acolá-então inexiste. Para os que se colocaram simpaticamente ao poema, o derradeiro quadro de uma verdureira aos berros, carregando uma cesta com seus produtos arranjados de forma estranha, parecendo um ser vivo, e um sujeito ao fundo, observando a cena, discretamente, o que se vê é tão grandioso quanto um quadro de Dante e Beatriz ou de qualquer outra cena de amor elevado. 


\section{AÇÃo}

A impressão doutros tempos, sempre viva, Dá estremeções no meu passado morto, E inda viajo, muita vez, absorto, Pelas várzeas da minha retentiva.

(NÓS, Cesário Verde) $X$

Olá, guardador de rebanhos,

Aí à beira da estrada, Que te diz o vento que passa?"

"Que é vento, e que passa,

E que já passou antes,

E que passará depois. E a ti o que te diz?"

"Muita coisa mais do que isso. Fala-me de muitas outras coisas.

De memórias e de saudades

E de coisas que nunca foram."

(O guardador de rebanhos, Fernando Pessoa)

A ação do sujeito que busca a beleza, que se metamorfoseia e que metamorfoseia aquilo que vê, a ação do tempo sobre as coisas, a ação da vida, em tudo o que ela contém, sobre o homem, a ação da arte sobre o mundo e a ação da arte como manutenção da experimentação e da memória: todos esses aspectos serão discutidos e percebidos em algumas poesias para que, finalmente, algumas trilhas e algumas ideias, possam encontrar o seu fim e a sua explicação. Nesta seção, mais do que em outras, os aspectos artísticos e reflexivos estarão concentrados em perceber a ação como uma proposição que explica a visão de mundo do artista e alguns dos mais importantes elementos de sua poética. Dois aspectos em torno da ação já foram aventados e serão retomados, para um maior aprofundamento: a dinamicidade própria e específica da obra, que a mundividência cesárea materializa na formatividade de sua poética, e a tentativa de, pela arte, manter a beleza que, ao final das contas, é também materialização do amor.

Se na primeira seção - LUZES - concentramos em iluminar o "objeto" central, em termos de recorrência e de reflexão, deste poética, que é a constituição do sujeito e toda a 
complexidade dela e como se percebe nos poemas; e se na segunda seção - OLHOS - o recorte se deu pelos mecanismos específicos do fazer artístico, apontando alguns elementos fundamentais nessa constituição, nesta seção - AÇÃO - cabe cumprir o aprofundamento das razões que se constitui um sujeito da forma como a obra o faz, com as especificidades artísticas e de mundividência, dando-lhes as razões e refletindo sobre elas em uma perspectiva mais profunda, tanto quanto possa ser mais ampla em termos de abarcar a poética em um todo. Nesse momento, também estaremos ampliando a noção de poética, ou para ser mais preciso, partindo dela para discutir questões de ordem ética. É, por assim, dizer, a terceira parte da alusão a uma fala específica utilizada por profissionais de vídeo e que pensamos não somente como ordenamento (que não se realizou tão estanque quanto o imaginado), mas porque a dinamicidade percebida nas poesias de Verde, além da forma de captar o real feita pelo poeta, nos parece tanto quanto o sujeito e sua câmera.

\section{Em busca da beleza perdida}

O sujeito que deambula, que flana, que é jóquei de uma tartaruga ou que corre atrás de carruagens, faz companhia ao indivíduo que colhe maçãs, levanta cestas, fuma cigarros, pisa em formigas. Nessa multiplicidade de formas de se construir e de ver o mundo, há um elemento em comum: todos buscam a beleza. Nosso questionamento era, em algumas partes deste trabalho, se todos buscavam a Beleza, isto é, ou uma beleza transcendente às coisas, idealizada. Espera-se que se tenha percebido diversos graus e tipos de beleza e formas de apreendê-la, para que possamos afirmar o que se segue: não há uma busca pela Beleza ideal ou transcendental, como fez um Pessoa, um Camões, em alguns casos Antero ou Pessanha. Há uma percepção da beleza imanente em todas as coisas, certamente dependente de um olhar que descobre segredos, em que tal beleza é apenas um passo em direção àquilo que ela representa ou que ela provoca: o amor. Esta palavra, este conceito, estarão no foco deste capítulo. Nesta seção, veremos o ato de busca-la, como se dá e como o amor aparece nesta busca ou na perda. Para isso, leremos e analisaremos a partir dessa chave o poema mais famoso do poeta: $O$ Sentimento dum Ocidental, pois nos permite verificar a dinâmica do sujeito dentro do poema, como ele vai reconstruindo o "real" e as sensações desta dita realidade, para encontrar e revelar a beleza, ao mesmo tempo que encontra e desencontra o amor, assim como também encontra e desencontra a beleza. 
Já parece claro pelo título que a voz poética não se limitará a reflexões teóricas ou filosóficas sobre o sujeito ocidental, e note-se como esses dois elementos, colocados como determinado e determinante, são complexos de discutir nessa paridade. Apesar da "quase" grandiloquência proposta pelo título pode sugerir, há, aqui e ali, alguns detalhes que o trazem para o rés-do-chão: a artigo indefinido um que aparece contraído com a preposição limita o “ocidental” a um indivíduo qualquer; sem este recurso ou utilizando artigo definido, o sujeito seria, por metonímia, o próprio ocidente. Cesário limita àquilo que é próprio: um ocidental qualquer representa o sentimento do homem comum desta parte do globo terrestre (e suas implicações não são poucas) e não o Homem ou a humanidade inteira. Também coloca como núcleo do título a palavra "sentimento", limitando-o a um único e essencial, como o qualifica o artigo definido que o antecede. Temos um par semântico formado por um léxico definido como essencial e outro como acidental. A palavra sentimento engana, no entanto, por aludir, à primeira vista, às sensações ou aos movimentos íntimos do sujeito, e veremos no poema que é, também, além das duas possibilidades, o resultado sensível de reflexões intelectuais, sintetizando em um sentimento, percepção sócio histórica e reflexões. Cabe, por último, compreender que se há um tom elevado no título, deve-se ao fato dele pretender ser um diálogo com Os Lusíadas de Camões, que era a proposta do poema ${ }^{22}$. A grandeza está presente, mas também a restrição à ela.

Nesse diálogo, ao contrário do tom épico e da instauração do tempo clássico e memorialístico própria da épica e dos recursos que a intertextualidade oferece, como erguer o edifício épico-camoniano sobre as colunas virgilianas (arma virumque cano), o poema iniciase por um prosaico "Nas nossas ruas, ao anoitecer". Compreendemos que o poema não se vale da estrutura da epopeia para se construir, mas é esse não se valer, ou seja, aquilo que é ausência explícita de diálogo - como negação ou apagamento do discurso ou texto base, mesmo que somente à nível discursivo e não textual-, também instaura uma demanda para reelaborar os sentidos desse mesmo texto a partir de tais posicionamentos. O tema a ser cantado pelo narrador na epopeia aparece em regra clássica no primeiro verso. "As armas e os barões assinalados"

\footnotetext{
${ }^{22}$ Em uma publicação extraordinária do Jornal de Viagens, do Porto, de 1880, denominada Portugal a Camões, surge pela primeira vez ao público o poema destacado, não recebendo qualquer atenção, para bem ou para o mal, como destaca o poeta ao amigo Macedo Papança em carta: "Uma poesia minha, recente, publicada numa folha bem impressa, comemorativa de Camões, não obteve um olhar, um sorriso, um desdém, uma observação. "
} (SERRÃO, 2003) 
dão lugar as "nossas ruas", e o recorte do momento específico "ao anoitecer". Colocando e perspectiva o que apontamos sobre o intertexto, se pode perceber que a epopeia, que é um canto elevado de um herói fundacional (que funda um povo ou Nação) ou de um povo (Os Lusíadas), perde completamente este "outrem" elevado e distante no tempo, para o local, o próximo, e coloca o sujeito, seu leitor e seu "povo" na mesma hierarquia. Além do "outrem" como instituição e como temporalidade (o tempo heroico do mito), também temos a diferença espacial: não se versará sobre a Lisboa de então ou sobre o Portugal erigido sobre a pedra eletiva de D. Afonso Henriques ou além-mar de Camões e Gama, mas sobre as ruas e vielas da Lisboa do século XIX, percebidas e captadas pelo olhar prosaico, despido tanto da "frauta doce" quanto da "tuba canora".

A negação ao recurso explícito do intertexto com o épico é também uma negação à beleza clássica: sendo esta um a priori estilístico/discursivo do belo clássico, o poema moderno precisa encontrar a beleza em si. A proporção, o equilíbrio, a voz altiva daquele gênero dá lugar neste poema a uma arquitetura estrutural clássica (decassílabos em quartetos), com seu “interior” permeado de diferenças e desequilíbrios: o terceiro verso é entrecortado de cesuras graves, ao contrário do andamento do verso heroico tradicional, com uma cesura grave, além de acentuações que alternam entre o sáfico e o heroico, ou sem qualquer classificação conhecida. Também pelas regras do tom elevado, as escolhas lexicais devem se pautar e preferir a palavra mais culta e rara às palavras coloquiais, caso que o poema abre mão. Por último, do tom edificante e grave da epopeia, resta a gravidade no poema oitocentista, sem, no entanto, “conseguir" a beleza que aquele proporciona. É a partir desse tom grave, soturno e melancólico, concordando com o expresso literalmente, que o sujeito define o aqui-agora do poema, em oposição ao Portugal heroico de então, e expressa um paradoxal "desejo absurdo de sofrer". Que o que lhe desperta está claro, “(...)as sombras, o bulício, o Tejo, a maresia”, pois são os sujeitos do verbo "despertam”, não possui tal evidência, tal desejo. Para compreendermos, teremos que acompanhar o sujeito por sua andança física e memorialística por este espaço e por este tempo. Antes do primeiro passo, deixemos claro que a menção ao Tejo, neste contexto, determina uma oposição imagética e valorativa entre o Tejo da "ocidental praia lusitana", de onde partiram as naus para conquistar o mundo e erguer a era de ouro Portuguesa, e este Tejo, com seus sons, aromas e imagem, carregados de semântica disfórica e negativa, do sujeito do século XIX. 
Nas nossas ruas, ao anoitecer,

Há tal soturnidade, há tal melancolia,

Que as sombras, o bulício, o Tejo, a maresia

Despertam-me um desejo absurdo de sofrer.

Os quadros que se seguem pintam um espaço em que não somente há ausência da vitalidade, como também da beleza. Na verdade, não há ausência: há a presença do oposto. A doença, a feiura, a felicidade distante, parecem resultar desta modernidade em que os elementos tecnológicos aprisionam, maltratam, matam os sujeitos. As sensações do eu poemático (lembrando que ele é o nós invocado no início do poema) são desdobramentos dessa observação em panorâmica (lembrando que Cesário monta o panorama através do detalhe, como quadros menores compondo o maior). O mundo a ser conquistado, neste momento, não é o de Gama, mas feito como turista ou como estrangeiro infeliz a buscar no exílio aquilo que a terra não mais oferece. A viagem ao exterior não é a para a conquista daqueles que levaram a "civilização" à "gente remota" ou às "terras viciosas", e sim a fuga da terra viciosa. Os conquistadores ocidentais, séculos depois, são os conquistados. O povo lusitano da nobre técnica da navegação, os baluartes do Renascimento, estão reduzidos à zoomorfização de saltar "Como morcegos, ao cair das badaladas", ou tapar buracos de embarcações (os calafetes), executando um trabalho braçal e perigoso, sem qualquer refinamento técnico ou cultural próprio dos países mencionados. O século XIX, "apogeu” da técnica, não chegou ainda a Portugal.

O céu parece baixo e de neblina,

\footnotetext{
${ }^{23} \mathrm{Na}$ edição de Silva Pinto há algumas diferenças das publicações impressas durante a vida do poeta: a primeira, uma dedicatória à Guerra Junqueiro; a segunda, que poderia oferecer alguns víeis interpretativos distintos, coloca subtítulos nas partes do poema, que, pela ordem, seriam: (I) Ave-Marias, (II) Noite Fechada, (III) Ao Gás, (IV) Horas Mortas. Utilizando a lógica de que o poeta escolhia léxicos com acepções múltiplas, mas coerentes com sua forma de ver/representar o mundo, os quatro subtítulos não fazem má figura. Todos consegue fazer uma marcação temporal e também aludir a questões sensoriais ou de anímica: das 18hs marcadas pelas Ave-Marias, avançamos na noite até a madrugada, as "Horas Mortas", bem como teríamos uma gradação do processo de "morte" do sujeito, que se inicia na oração e vai até a palavra literal. Por último, cabe ressaltar como o subtítulo "Ao Gás" lembra a verve irônica do poeta. Não sendo dele as sugestões ou mudanças e postas pelo organizador, temos aqui novamente o conceito pareysoniano de congenialidade explicando como Silva Pinto compreendeu com esses quatro subtítulos a arte do amigo. Não levamos em consideração, no entanto, para mantermos o critério adotado em todos os outros poemas. Sobre a dedicatória, parece coisa do organizador de fato.
} 
O gás estravassado enjoa-me, perturba;

$\mathrm{E}$ os edifícios, com as chaminés, e a turba

Toldam-se duma cor monótona e londrina.

Batem os carros de aluguer, ao fundo,

Levando à via-férrea os que se vão. Felizes!

Ocorrem-me em revista, exposições, países:

Madrid, Paris, Berlim, S. Petersburgo, no mundo!

Semelham-se a gaiolas, com viveiros,

As edificações somente emadeiradas:

Como morcegos, ao cair das badaladas,

Saltam de viga em viga os mestres carpinteiros.

Voltam os calafates, aos magotes,

De jaquetão ao ombro, enfarruscados, secos;

Embrenho-me, a cismar, por boqueirões, por becos,

Ou erro pelos cais a que se atracam botes.

Diante de tanta desilusão e sensações negativas, o sujeito começa o seu processo de deambulação, de busca e de descobrimento e de tentativa de transformação da descoberta em beleza. Pela ação do primeiro, vai percorrendo toda a cidade e observando os seus habitantes; pelo segundo, a partir da evocação e do olhar concentrado, descobre aqui e ali, resquícios da beleza; pela terceira ação, tenta retirar da beleza efêmera e discreta, um ânimo e sentimento que o transforme e o resgate do ensimesmamento e da apatia. Da primeira ação, percebemos um estado de inquietação e de ausência de direção tanto psicológica quanto física: no caso da ausência física, o andar sem direção ou sem aparente lógica traça, na cidade, uma espécie de labirinto que sugere a materialização da falta de ordem, de lógica, de beleza, da urbe, pelos séculos dos séculos e tendo o ápice da errância no momento do poema. O sujeito, tal qual nau sem rei e sem terras a conquistar, erra por onde pode, sem vínculo e sem destino. A cidade, produto dos séculos de um ocidente pouco generoso com a terra, é construída com seus arremates e suas improvisações, perdida. Dos navegantes que circundaram o mundo e descobriram novas rotas por "mares nunca dantes navegados", com uma espécie de intuição sobrenatural para cumprimento de uma missão além das forças humanas, o que resta é, diz-nos 
o andarilho nervoso, um povo sem identidade, sem moral e sem beleza, logo, sem possibilidade de amar e ser amado.

Esse espaço labiríntico não é uma metáfora do sujeito: é uma metonímia da história da pátria portuguesa. Dessa forma, por esse processo, através de quadros, o sujeito vai compondo a História Portuguesa vista por dentro, do alto do século XIX, distante e fora do clássico lusitano. É nele, que a segunda ação se vale:

E evoco, então, as crônicas navais:

Mouros, baixéis, heróis, tudo ressuscitado!

Luta Camões no Sul, salvando um livro a nado!

Singram soberbas naus que eu não verei jamais!

E o fim da tarde inspira-me; e incomoda!

De um couraçado inglês vogam os escaleres;

E em terra num tinir de louças e talheres

Flamejam, ao jantar, alguns hotéis da moda.

A evocação é um processo duplo: ao mesmo tempo que presentifica uma representação, reforça a ausência da coisa, dado que a representação não traz a experimentação, nem a coisa em si. A evocação é também um ato explícito de resgate do passado ou do ausente. Dessa forma, como ato voluntário, faz revelar a necessidade e a vontade dessa ausência ao mesmo tempo que pretende negar o presente real e as presenças em torno de si. Vale refletir também na etimologia da palavra, formada pelo radical evo, derivado do latim aevum, que significa, segundo o Houaiss(2008), “duração contínua, tempo que não termina, eternidade”. O exercício voluntário da memória e da imaginação do tempo camoniano não quer somente romper as leis da Física, mas romper os limites humanos e da História, fazendo do tempo presente da poesia um continuum da grandeza de outrora.

O tempo flui, como um rio, aquele ao qual Heráclito disse que não podemos descer duas vezes. Há, basicamente, duas maneiras de conceber o fluxo do tempo: desde o passado em direção ao futuro, ou desde o futuro em direção ao passado (BORGES, 1960). Em qualquer um dos casos, o fluxo nos atravessa num ponto, que denominamos presente. Um ponto não tem superfície nem volume; é intangível e fugaz. É curioso que, em ambas concepções do tempo, o futuro (ou o passado) sejam consequências de algo 
quase imaterial como é o presente; de um simples ponto. Esse ponto evanescente, porém, é nossa única posse real: o futuro não existe ainda (e a palavra ainda é uma petição de princípio) e o passado não mais existe, salvo sob a forma de memórias. Não há tempo sem um conceito de memória; não há presente sem um conceito do tempo; não há realidade sem memória e sem uma noção de presente, passado e futuro. Memória são as ruínas de Roma e as ruínas de nosso passado; memória tem o sistema imunológico, uma mola e um computador. Memória é nosso senso histórico e nosso senso de identidade pessoal (sou quem sou porque me lembro quem sou). Há algo em comum entre todas essas memórias: a conservação do passado através de imagens ou representações que podem ser evocadas. Representações, mas não realidades: as ruínas de Roma não são a Roma imperial; um disco da Nona Sinfonia gravado por Toscanini, Karayan ou Kleiber não equivale à sua execução, nem à Nona Sinfonia que Beethoven concebeu. (IZQUIERDO, 1989)

É notável como a evocação presente na sexta estrofe formatiza-se em uma das poucas estrofes de tom eufórico, de ritmo heroico e de Sublime embelezamento. Entretanto, também na própria estrofe, no seu último verso, temos a constatação da impossibilidade de ver a grandeza das navegações, representadas pelas naus e pelo esforço camoniano (também episódico, ao salvar a nado Os Lusíadas, como nos diz o mito) para construção da Obra que assombra o povo e determina o ideal de beleza da História e da arte portuguesa. Dessa feita, o "fim da tarde", quando o sol está se pondo ao horizonte do Tejo, a inspiração que tira o sujeito de si e lhe concede vislumbrar a altivez da cidade, da terra e do povo, também o incomoda, exatamente por se tratar de sombras de um passado. Elas são indícios da coisa, muitas vezes com formas e tamanhos exatos ao objeto, mas nunca ele em si. Temos as três ações anteriormente apontadas, aqui realizadas: a busca, a evocação e descoberta, e um diferente ânimo. Como, no entanto, estamos no labirinto sentimental dum ocidental à deriva, o fio de Ariadne que nos guia é feito da mesma matéria produzida ao tom da meia-luz: sonhos, evocações e sombras. Por isso, ao quadro elevado, temos a contraposição de uma realidade disfórica, concretamente feita de "couraçado inglês", sons de "louças e talheres", povoada de "dentistas" e "Um trôpego arlequim".

São esses os quadros majoritários do poema: os ordinários habitantes e a comum vida ocidental moderna, em seu fim de tarde e noite finissecular, neste espaço ocidental de ruínas 
romanas, odisseicas pegadas e tímidos acordes do Trinca-Fortes. ${ }^{24} \mathrm{O}$ pintor desses quadros, na ausência do sol edificante, empresta também para a sua paleta as tintas baudelairianas e uma antevisão do Expressionismo (D’ÁVILLA, 2016), carregando de exageros mórbidos e explorando pela distorção a "feiura" do que vai captando. Não se trata, no entanto da estética do feio da poeta francês aplicada a rodo: é a voz da modernidade do poeta ocidental moderno por excelência que aqui empresta o tom para tornar o "feio" um posicionamento ideológico e estético. O tomar emprestado também não significa, imediatamente, uma homenagem ou uma rendição: pelo contrário, nos parece que a voz francesa é também criticada, já que ela se presta para acentuar o aspecto mórbido, grotesco e desumano das pessoas, do espaço e do tempo. Se está no Quinhentismo português o dado positivo - ressalta-se, o único dado positivo e elevador - dentro do poema, o Ocidente finissecular Oitocentista deve ser representado por outra "frauta" ou tuba: é através desse filtro que o sujeito vai observando o mundo.

Num trem de praça arengam dois dentistas;

Um trôpego arlequim braceja numas andas;

Os querubins do lar flutuam nas varandas;

As portas, em cabelo, enfadam-se os lojistas!

Vazam-se pos arsenais e as oficinas;

Reluz, viscoso, o rio, apressam-se as obreiras; E num cardume negro, hercúleas, galhofeiras, Correndo com firmeza, assomam as varinas.

Vêm sacudindo as ancas opulentas!

Seus troncos varonis recordam-me pilastras;

E algumas, á cabeça, embalam nas canastras

Os filhos que depois naufragam nas tormentas.

Descalças! Nas descargas de carvão,

Desde manhã à noite, a bordo das fragatas;

E apinham-se num bairro aonde miam gatas,

E o peixe podre gera os focos de infecção!

\footnotetext{
${ }^{24}$ Um dos apelidos de Camões.
} 
Na segunda parte do poema, o sujeito sai do cais do porto, subindo em direção ao centro. $\mathrm{Na}$ sua andança, física e memorialística, diluirá novamente o passado e o presente, e, novamente, construirá quadros valorativos, olhando com concentração os diversos aspectos do espaço/tempo português da sua época, colocando-os em perspectiva com o tempo do mito. Daí que um léxico como "Aljube" ${ }^{25}$ nos dê essa dilatação de tempo e também empreste as notações valorativas próprias perceptíveis em uma prisão para clérigos que se transforma em prisão para mulheres comuns. As quatro estrofes que abrem a segunda parte polemizam o papel do clero e de alguns homens desta igreja, na perspectiva histórica (da Inquisição) e no presente do poema. Mas é a visão das "Cruzes, da "Sé”, que, novamente, assim como a visão das naus, altera o seu estado anímico para um choro de um "coração que se enche e que se abisma”. É essa visão, dessa instituição, que o remete ao passado: dali, da Sé, em sentido contrário ao que o sujeito vem percorrendo, saiam as procissões em direção ao cais, à praia do Restelo, de onde, tal qual ele, os marinheiros pela história se aventuraram e se alargaram. Os homens que dilataram a Fé e o Império à custa de suas forças, juventude e próprias vidas, estão ausentes desta segunda parte do poema: dali, da Sé, em procissão, desceram, embarcaram, ouviram o vaticínio de um velho de aspecto venerável, que também não mais brada suas lições contra a vanglória. O som que permanece é o das grades da cadeia ou dos sinos das igrejas. Não há notação de homens no tempo presente, além das mulheres, das crianças e das velhinhas. As referências ao feminino são vastas(as costureiras, as floristas) neste tempo presente, mas o masculino aparece distanciado no tempo, como figuras históricas, militarizadas e, alegorizadas como as "armas" pós navegações. O alerta dado pelo Velho não foi ouvido e cá estamos, diz o poema, no presente histórico que é resultado daquele passado.

25 “O edifício do Aljube terá sido utilizado como instalação prisional desde a ocupação muçulmana de Lisboa (sécs. VIII - XII). Usado posteriormente como prisão eclesiástica, sofre sucessivas adaptações até se tornar, na viragem do séc. XVI para o XVII, palácio de arcebispos, continuando, no entanto, a ser usado como cadeia para presos do foro eclesiástico. A designação Aljube equivalente a prisão do foro eclesiástico populariza-se, como se pode verificar com o Aljube da cidade do Porto, a cadeia do Aljube em Ponta Delgada, nos Açores, ou a cadeia eclesiástica de Olinda, Pernambuco, no Brasil. O Terramoto de 1755 não afeta gravemente o edifício do Aljube, embora o alargamento da rua que o separa da Sé viesse a provocar o recuo da sua fachada. Só após o Liberalismo, a cadeia do Aljube perde essa função, sendo destinada a presos de delito comum, tornando-se, mais tarde, uma prisão de mulheres, conhecida pelas suas condições degradantes - destino que se manterá durante a I República.” In: https://pt.wikipedia.org/wiki/Cadeia_do_Aljube. Acesso: 29 Nov 2016. 
Neste ponto físico, mais alto do que no início do poema, que, vale lembrar, nos coloca em um in media res geográfico e temporal, que nos localiza no cais do porto e no fim da tarde, equivalente ao meio do poema, e equivalente ao meio do caminho até o destino final e ao meio do tempo até o findar do poema e do início do próximo dia(dado pelo sol e não pelo relógio), o indivíduo encontra um "Brônzeo, monumental, de proporções guerreiras,/Um épico doutrora ascende, num pilar!": a estátua de Camões ${ }^{26}$. Ele, no entanto, aparece metonimizado pela palavra "épico doutrora", sendo esta a declarada escolha, entre o soldado-navegador e o amador-poeta, que o olhar decide resgatar e manter. Esta altivez "masculina", concentrada no aspecto artístico, opõe-se e desperta uma dialética com o sujeito de "luneta de uma lente só", que, prosaicamente, na brasserie, encontra "alimento", assunto e diversão no dominó. Não seria, por analogia, as letras francesas um "alimento" para o poeta português? E sendo assim, não há um aspecto crítico, pela ironia, à luz do épico de outrora, ter que se alimentar de coisas estrangeiras, abrindo mão da "culinária" local e conterrânea? Além do épico de outrora e sua caneta épica, outras tintas portuguesas: vale lembrar que há um poema, dedicado a João de Deus, que Cesário assina com um pseudônimo feminino (Margarida), louvando o poeta português, sua técnica e sua temática, como em nenhum outro poema se faz ${ }^{27}$. A metonímia também utilizada para caracterizar o sujeito retira-lhe a força e altivez presente na estátua e na

${ }^{26} \mathrm{O}$ conjunto escultórico, dito Monumento a Camões, em Lisboa, é da autoria do escultor Victor Bastos, foi projetado a partir de 1860 e inaugurado em 1867, na presença do rei D. Luís e de seu pai D. Fernando, rei consorte. Foi construído já no final do romantismo e custeado por subscrição pública. O monumento prepara e antecede as comemorações do terceiro centenário da morte de Camões, promovidas por Teófilo Braga com o apoio de João de Deus, Antero de Quental, Oliveira Martins e Ramalho Ortigão. A estátua evocativa do poeta é de bronze e mede 4 metros de altura. Assenta sobre um pedestal, oitavado, de mármore branco, com 7,5 metros de altura. Em redor do pedestal oito estátuas, de pedra de lioz, de 2,40 metros de altura, representam vultos notáveis da cultura e das letras: o historiador Fernão Lopes, o cosmógrafo Pedro Nunes, o cronista Gomes Eanes de Azurara, os historiadores João de Barros e Fernão Lopes de Castanheda e os poetas Vasco Mouzinho de Quevedo, Jerónimo Corte-Real e Francisco de Sá de Meneses. A estátua de Camões foi desde logo e tem sido motivo de crítica pela "pose" demasiado militar e muito pouco romântica do poeta. A escultura invoca o poeta vestido a rigor, de espada em punho, livro no peito e coroa de louros na cabeça, numa atitude altiva. Os representados na base do monumento sucedem-se ao longo da dinastia de Avis: são os espectadores vivos da grandeza (Fernão Lopes, Azurara, João de Barros, Castanheda, Pedro Nunes) e da decadência da pátria (Quevedo, Corte-Ral e Sá de Menezes). In: https://pt.wikipedia.org/wiki/Monumento_a_Cam\%C3\%B5es. Acesso: 03 Dez 2016.

${ }^{27}$ Sobre especificamente este poema e uma leitura que o considera chave na mundividência de Cesário, vale a pena ler o trabalho de Janet Carter, indicado na bibliografia. 
memória do bardo português, dando-lhe uma fragilidade e também colocando a técnica (os óculos) como muleta dos fracos e sem "visão". Anterior a isso, temos todo o quadro dos séculos de doenças e desastres que o espaço ali presenciou, pelos séculos: a Peste Negra, as Cruzadas, as revoltas e revoluções. Esses, são exclusivos do mundo masculino, montado a cavalo. $\mathrm{O}$ feminino, tanto quanto falho de caráter, está no tempo presente. Dois universos que coexistem enquanto "derrota", mas que, temporalmente, segundo o poema, deve, o feminino, a sua derrocada ao passado masculino e suas escolhas - em regra, belicosas. Ecoa a voz do Restelo ainda.

\section{II}

Toca-se às grades, nas cadeias. Som

Que mortifica e deixa umas loucuras mansas!

O Aljube em que hoje estão velhinhas e crianças,

Bem raramente encerra uma mulher de "dom"!

E eu desconfio, até, de um aneurisma

Tão mórbido me sinto, ao acender das luzes;

A vista das prisões, da velha Sé, das Cruzes,

Chora-me o coração que se enche e que se abisma.

A espaços, iluminam-se os andares,

$\mathrm{E}$ as tascas, os cafés, as tendas, os estancos

Alastram em lençol os seus reflexos brancos;

E a Lua lembra o circo e os jogos malabares.

Duas igrejas, num saudoso largo,

Lançam a nódoa negra e fúnebre do clero:

Nelas esfumo um ermo inquisidor severo,

Assim que pela História eu me aventuro e alargo.

Na parte que abateu no terremoto,

Muram-me as construções retas, iguais, crescidas;

Afrontam-me, no resto, as íngremes subidas,

E os sinos dum tanger monástico e devoto.

Mas, num recinto público e vulgar, 
Com bancos de namoro e exíguas pimenteiras,

Brônzeo, monumental, de proporções guerreiras,

Um épico doutrora ascende, num pilar!

E eu sonho o Cólera, imagino a Febre,

Nesta acumulação de corpos enfezados;

Sombrios e espectrais recolhem os soldados;

Inflama-se um palácio em face de um casebre.

Partem patrulhas de cavalaria

Dos arcos dos quartéis que foram já conventos:

Idade Média! A pé, outras, a passos lentos,

Derramam-se por toda a capital, que esfria.

Triste cidade! Eu temo que me avives

Uma paixão defunta! Aos lampiões distantes,

Enlutam-me, alvejando, as tuas elegantes,

Curvadas a sorrir às montras dos ourives.

E mais: as costureiras, as floristas

Descem dos magasins, causam-me sobressaltos;

Custa-lhes a elevar os seus pescoços altos

E muitas delas são comparsas ou coristas.

E eu, de luneta de uma lente só,

Eu acho sempre assunto a quadros revoltados:

Entro na brasserie; às mesas de emigrados,

Joga-se, alegremente e ao gás, o dominó.

Neste espaço, sob tais condições, a referência aos magasins acaba por ressaltar ainda mais o dito sobre as fontes patrícias como base para a beleza: a moda francesa, "europeia", impõe-se sobre a moda compatriota, mais "natural" e afetiva, o que, somados, equivalem a dizer mais belos. A beleza do quadro em que se coloca a estátua de Camões salta ainda mais aos olhos à perspectiva de diversos quadros em que o grotesco e o feio dão a tonalidade pesada da "realidade" vertida sob a luneta de um olho só do sujeito doente. Nada nesse espaço é salutar ou afetivo, e a alegria da companhia restringe-se aos emigrados e o jogo de dominó. O nome 
provavelmente deriva da expressão latina domino gratias, que significa "graças a Deus", dita pelos padres europeus enquanto jogavam, o que, novamente, destaca neste poema a dupla existência da vida leiga e da vida religiosa em inquebrantável aliança: a Fé e o Império existem um graças ao outro. Também a decadência se dá ao par, em que cada um, em alguma medida e em algum tempo, provoca a e aprofunda os males em si e no outro. Todo o aspecto mórbido e todas as referenciações e alusões à morte andam em dupla. Mas, assim como há uma relação de causa e efeito no par masculino e feminino, a causa da decadência presente está em que um, a Fé, não se altera, enquanto o outro, o Império, se transfigurou de tal forma, que é irreconhecível. Nada aproxima o sujeito afetivamente dali, além do artista clássico. A beleza ali não é somente pelo clássico em si, mas por ser o clássico português por excelência, isto é, canta o peito lusitano.

Assim, a terceira e quarta parte cumprem a função que na epopeia camoniana define-se como ápice e conclusão: lá, o ápice se dá no Canto IX, quando é dado ao Gama, guiado por Tétis, vislumbrar a "máquina do mundo", e com tal chave, compreender o papel de Portugal no universo arquitetado por Deus. Mas também lá, o final, o Canto X, é disfórico e pessimista. No poema verdiano, o presente disfórico agora é o desenvolvimento histórico daquela antevisão camoniana da terra metida na vanglória, nos desmandos e no egoísmo. Entretanto, o talento camoniano arquiteta um mito que eleva a História e o próprio povo. E o poeta citadino moderno? Qual seu papel? Como elevar este mundo em decadência, sem ter a História como material? E porque elevar e não "criticar" ou "distopizar" a sociedade e suas representações? Essas preocupações parecem encaminhar o fechamento do poema e encerrar o diálogo com a poesia clássica, além de esclarecer o sentimento dum ocidental do título.

De certos quadros pode-se perceber a tentativa da construção da beleza pelo uso da isometria construída em decassílabo, além de alguns recursos, notadamente a plasticidade e a sinestesia, para retirar do "real", do cotidiano e do humilde, resquícios de beleza. Esses quadros estão ligados ao trabalho, componente caro a Cesário. Em compensação, o ato religioso é distorcido até que se consiga o efeito de desconforto e fealdade potencializada:

As burguesinhas do Catolicismo

Resvalam pelo chão minado pelos canos;

E lembram-me, ao chorar doente dos pianos,

As freiras que os jejuns matavam de histerismo. 
Num cuteleiro, de avental, ao torno,

Um forjador maneja um malho, rubramente;

E de uma padaria exala-se, inda quente,

Um cheiro salutar e honesto a pão no forno.

À vista disso, o movimento disfórico/eufórico, quando em sequência, intensifica o "mal" presente em um, enquanto "dignifica" ainda mais o outro. Em um, a morte e a doença estão presentes; no outro, há vitalidade e saúde. O primeiro quadro é digno do Expressionismo em termos de hipérboles e distorções, enquanto o segundo é típico do poeta, a encontrar a beleza no cotidiano. Assim, novamente tomado pelo ânimo da beleza, que lhe é afeto e saúde, ele continua a sua andança e suas reflexões. Após novamente encontrar a beleza escondida nesta cidade doente, ele reflete sobre a própria arte, metapoeticamente: " $\mathrm{E}$ eu, que medito um livro que exacerbe,/ Quisera que o real e a análise mo dessem:” Exacerbar pode tanto significar estimular, quanto irritar, azedar, e ambas as possibilidades explicam "o livro" que o artista medita. Tais possibilidades também estavam no efeito d'Os Lusíadas: estímulo pela grandiloquência da História mitificada e elevada; irritação pelas soluções e pela observação dos males do mundo. O modo de realizar o objeto artístico, pelo real e pela análise, entretanto, se distancia do canto que se faz com engenho e arte: aquele é o método realista/naturalista/cientificista próprio do final do XIX; o segundo, o fazer artístico do poeta clássico e tomado pelas musas. Mesmo compreendendo ser este um elemento retórico próprio da arte clássica, não é a realidade sensível um modo, nem um tema, nem objetivo, da arte elevada (é da arte humilde, com suas estâncias lembrando pastoras e mulheres do campo). Percebemos ainda, que o uso do modo verbal no subjuntivo em "dessem", complementando o verbo no indicativo do pretérito-mais-que-perfeito "quisera", anuncia em si, uma impossibilidade e uma distância de tal ação. A intenção era essa: um livro sobre e do real, captado pelo olhar analítico. Os dois pontos que antecedem os dois últimos versos dessa estrofe são o exemplo dessa arte: “Casas de confecções e modas resplandecem;/Pelas vitrines olha um ratoneiro imberbe." Mas se realiza, porque há uma sensação de impossibilidade? A resposta está na estrofe seguinte e em outra da parte IV:

Longas descidas! Não poder pintar

Com versos magistrais, salubres e sinceros,

A esguia difusão dos vossos reverberos,

E a vossa palidez romântica e lunar! 
E eu sigo, como as linhas de uma pauta

A dupla correnteza augusta das fachadas;

Pois sobem, no silêncio, infaustas e trinadas,

As notas pastoris de uma longínqua flauta.

Se eu não morresse, nunca! E eternamente

Buscasse e conseguisse a perfeição das cousas!

Esqueço-me a prever castíssimas esposas,

Que aninhem em mansões de vidro transparente!

Assim como em outros pontos deste trabalho, aqui também estamos em flagrante redundância, quando dizemos que toda a crítica se debruçou sobre tais versos e os considerou uma manifestação e uma reflexão metalinguística que perpassa toda a obra de Cesário. Cada um, a seu modo, apresenta argumentos sólidos, coerentes e variados para embasar o dito. Pouco acrescentamos em relação ao geral. Há três aspectos fundamentais, complementando o que foi dito sobre a reflexão metapoética já iniciada, que coloca um distanciamento do método analítico (que nos parece ter sido utilizado na forma do olhar concentrado e do olhar em distensão) e do real, já que apresenta o ato de pintar com "versos magistrais, salubres e sinceros", a sedução das “(...)notas pastoris de uma longínqua flauta” e, principalmente, o objetivo do fazer artístico, que é "eternamente/Buscasse e conseguisse a perfeição das cousas". A pintura como intertexto permanente do poeta é evidente, mas é a coisa "magistral", isto é, o quadro que capta com perfeição não o real, mas a sensação de tal realidade, filtrada e "exprimida" para revelar uma inusitada beleza que é "salubre", posto que é sensação afetiva, sincera. A pintura, como plasticidade que recria um outro "corpo", ou, como preferimos, um novo ser, com sua ontologia própria, e é, por isso, eterna enquanto arte. Buscar e conseguir, ainda que no condicional, são ações em contínua e perpetua realizações feitas por esse olhar de um sujeito em constante e incessante busca do belo nas coisas do mundo e de representa-lo e mantê-lo no objeto artístico. Se Camões contava com a inspiração das Tágides, para que seu gênio encontrasse a técnica (a ars) e conseguisse realizar a obra, Cesário mostra que está ali, na vitrine, no homem comum (ou até mais humilde do que o comum), no trabalho desprezado, nas modas efêmeras e passageiras, seus leitmotivs e suas musas.

Assim, podemos pensar que há duas ausências em relação ao épico camoniano no poema moderno: a companhia de Tétis, guiando-o até o topo da Ilha dos Amores e a Máquina do 
Mundo. O sujeito deambula solitariamente, sem guia, sem musas, e sem recompensa. Principalmente, lhe é vedado a experiência amorosa: ela existe apenas como uma aproximação à beleza, mas neste espaço, nessas condições, o sujeito, metáfora da nau camoniana, não encontra mais, no retorno, as recompensas da famosa ilha. É verdade que o professor de Latim alude novamente ao velho do Restelo, mas agora sem a dignidade do outro: é só uma lembrança de algo distante, quer seja da língua, que agora se transforma pelos neologismos, quer pela lembrança do passado pessoal do sujeito, em conjunção com o passado heroico e medieval do Velho. Sem a Ilha dos Amores, que ecoa na longínqua flauta, o sujeito tem um único sentimento: a dor. Sem a Máquina do Mundo e sua proposição lógica de organização do universo, a dor torna-se o Gigante Adamastor a reclamar de sua própria dita amorosa e vaticinar desastres aos navegantes. Desproporcional, essa dor, do sujeito que sequer pode ver do mais alto ponto, é agora o mar. O mar camoniano, que era desafio e conquista, mas também caminho para a glória, reduz-se a dor humana, e caminho para o esquecimento e para a decadência. $\mathrm{O}$ passado heroico encerra-se definitivamente no presente distópico, moderno e solitário, comprometendo, inclusive, o futuro. Sem beleza e sem amor, a arte é túmulo e renúncia. O sentimento dum ocidental é luto, em três tempos.

Ó nossos filhos! Que de sonhos ágeis,

Pousando, vos trarão a nitidez às vidas!

Eu quero as vossas mães e irmãs estremecidas,

Numas habitações translúcidas e frágeis.

Ah! Como a raça ruiva do porvir,

E as frotas dos avós, e os nômadas ardentes,

Nós vamos explorar todos os continentes

E pelas vastidões aquáticas seguir!

E, enorme, nesta massa irregular

De prédios sepulcrais, com dimensões de montes,

A Dor humana busca os amplos horizontes,

E tem marés, de fel, como um sinistro mar! 


\section{Retratos íntimos ou a arte como antídoto ao efêmero}

Na seção anterior, ao discutir a metapoética proposta pelo autor, mostramos que a arte é para ele um buscar e um conseguir que anula o tempo, pois é permanência e eternidade.

Se eu não morresse, nunca! E eternamente

Buscasse e conseguisse a perfeição das cousas!

Buscar e conseguir a perfeição das coisas nos parece muito além de simplesmente retratar a realidade ou depurá-la: há um efetivo trabalho laboral e autoral em torno da realidade, para que a perfeição (que não existe) possa ser "conseguida", isto é, construída enquanto objeto artístico. Esse objeto, a arte, além de sua dimensão estética sensorial, é, especificamente, uma proposição de permanência das sensações e da experiência vivida, traduzida pela memória e realizada pela poética. Esta é a proposição principial do sujeito Cesário e é esta também o centro ontológico de sua obra. É em torno de experiências sensoriais e afetivas que a beleza, que ele busca e encontra, proporciona, o sujeito, exatamente porque tais sensações e experiências estão sempre em perigo pelo aspecto fugaz deles, o sujeito vai reconfigurando a memória para que possa mantê-las. É a obra como antídoto ao efêmero: é a busca de manter a sensação pela construção de outro objeto sensível, que provesse, com as devidas distâncias e limitações, a reexperimentação dessas sensações. Mas se a sensação essencial é o amor, e ele é percebido como efêmero, como construir uma arte que possa permitir não a apreensão intelectual do amor, mas ele-em-si, enquanto sensações próprias que derivem dele? E mais importante, como congelar a efemeridade, quer seja a passagem do tempo, quer revelando o detalhe escondido, o elemento secreto, e deixa-lo evidente? São essas as perguntas que movimentam e articulam a poética presente, em nossa leitura.

A arte é para Cesário uma necessidade constitutiva de si e do mundo. Por isso, grande parte dos poemas tratam de apresentar um sujeito, em regra, com aptidões poéticas, amante de alguma mulher impossível ou de algumas situações do cotidiano. Essas situações do cotidiano estão invisíveis aos comuns humanos, preocupados consigo e com o ritmo acelerado de uma sociedade industrial (ou em processo de): o trabalhador e a beleza do seu trabalho estão teorizados em um poema de Antero de Quental, mas isso é coerente com a obra do poeta açoriano: o trabalho para Antero é visto a partir de teorias marxistas ou ditas revolucionárias, nunca como experiência vivida, experimentada e possuída. Para Cesário, o trabalho do 
cotidiano também faz parte de sua vida, e seu olhar divide-se entre o olhar poético e o do homem útil, a contar pilhas de tábuas ou metros de chita. Ao homem prático, soma-se o amador incansável. Este olhar cuidadoso se reflete também em uma construção poética que pretende ser, como superestrutura, cuidadosamente regrada e medida. Esse olhar e sua vontade de encontrar a beleza, também percebe a dinâmica e a instabilidade das coisas, já que, em grande parte, o belo é físico e, quando deriva de belas ações, tem uma possibilidade de permanência per si muito maior. À beleza física, as leis da natureza são implacáveis; as belas ações, derivadas do amor, são imunes ao tempo.

Como é possível então construir e representar a dinâmica da efemeridade através da arte? Como é possível obter o efeito de perceber a passagem das coisas, revelar o segredo contido no pequenino, desvelar a beleza e o afeto contido na fruição dela? Principalmente, como e por que pretender romper com as leis físicas para guardar e manter a beleza e o afeto? As respostas a essas perguntas e outras que deixamos em suspenso aqui e ali, sintetizarão as diversas leituras feitas e as encaminharão para um fechamento em torno daquilo que pensamos ser a motivação principal, bem como um aspecto essencial, em nossa leitura, da poética de Cesário Verde.

A construção do efeito da dinâmica necessita, como percebemos durante a leitura de diversos poemas, de recursos da linguagem que possibilitem não somente a definição lógica e conceitual de tal sentido: a poesia de Cesário não é feita de teorizações ou de conjecturas filosóficas explícitas; mesmo a discussão em torno de sua poética é apresentada em maior profusão no caso, isto é, na apresentação do artista fazendo a arte do que em elaboradas digressões metapoéticas. Temos o artista em seu ambiente próprio, no momento da inspiração, compartilhando suas sensações e, ocasionalmente, comentando o que faz. Nessas ações é que a dinâmica surge enquanto temática e modo de construção interna ao poema, e é no poema acabado e suas soluções artísticas que a dinâmica se impõe enquanto estrutura e estilística externas do poema; por último, os poemas formam uma organicidade, que é a obra do poeta, revelando no todo a coerência de cada parte, além de permitir perceber a dinâmica de mudanças e de posicionamentos distintos ou consecutivos.

A temática da beleza, como a vê Verde, está intimamente e indissoluvelmente ligada à temática amorosa e esta, ao seu par oposto, a morte. A beleza física contém em si o fascínio 
dessa dicotomia, e principalmente, a dinâmica da efemeridade. Aliás, é sobre isso que trata no poema Ironias do Desgosto:

"Não vês como a campina é toda embalsamada

"E como nos alegra em cada nova flor?

"Então por que é que tens na fronte consternada

"Não sei que de tocante e de enternecedor?"

E eu só lhe respondia: - "Escuta-me. Conforme

"Tu vibras os cristais da boca musical,

"Vai-nos minando o tempo, o tempo - o cancro enorme

"Que te há-de corromper o corpo de vestal.

"E eu calmamente sei, na dor que me amortalha,

"Que a tua cabecinha ornada à Rabagas,

"A pouco e pouco há-de ir tornando-se grisalha

"E em breve ao quente sol e ao gás alvejará!

"E eu que daria um rei por cada teu suspiro,

"Eu que amo a mocidade e as modas fúteis, vãs,

"Eu morro de pesar, talvez, porque prefiro

"O teu cabelo escuro às veneráveis cãs!"

Note-se que o poema é construído em diálogos, diluindo a separação entre os gêneros lírico e dramático, e colocando na dinâmica do diálogo, dois distintos mundos: um, representado pela voz feminina, estereótipo da jovem e bela burguesa de fins do século XIX; o outro, a voz do sujeito poemático, revela a consciência da efemeridade da beleza e, ainda, a sua condição de amante dessa fugacidade. Neste caso, temos a dinâmica da efemeridade explícita e tematicamente tratada. Na maioria das situações, o sujeito enamorado de alguma bela mulher, sofre por essa condição. Essas belas mulheres, entretanto, são caracterizadas utilizando-se principalmente o recurso da referenciação à moda, que pode ser ou não a do século correspondente à vida do poeta. A própria menção ao conceito de moda já alude a ideia de mudanças constantes de gostos e da efemeridade em si. Por outro lado, percebe-se que a forma de apresentar a beleza feminina é também uma tentativa de manter a sensação causada por tal deleite: aos "poucos", metonimicamente, concentrando o olhar em cada detalhe, o sujeito vai 
compondo a totalidade da mulher. Essa forma alonga a sensação do belo, pois vai construindo e descrevendo a beleza feminina sem apressar-se em mostrar o todo imediatamente. É possível utilizar o termo "fetiche" em grande parte desses usos, já que o sujeito se perde nessa sensação e na imagem mostrada, mas em alguns casos, quando a beleza não é somente externa, mas deriva de ações, o mesmo recurso revela generosidade e afetividade. Lembremos da verdureira de Num Bairro Moderno ou da passadeira de Nevroses. Nesses dois opostos belos, temos a mudança da beleza externa, que exige o congelamento do tempo para sua manutenção, fato impossível e que causa grandes dissabores ao sujeito, e a beleza das ações, que também pressupõe uma duração e por isso efêmera enquanto valor de uma sociedade metida nas sensações físicas ou ensimesmadas. A preservação do afeto distinto que delas deriva é a busca do poeta:

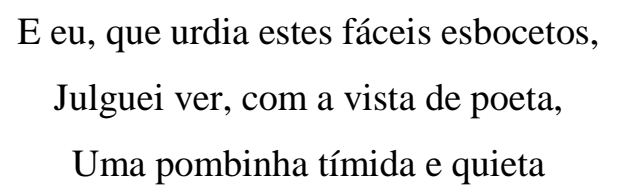

Num bando ameaçador de corvos pretos.

E foi, então, que eu, homem varonil,

Quis dedicar-te a minha pobre vida,

A ti, que és tênue, dócil, recolhida,

Eu, que sou hábil, prático, viril.

Outro ponto que aqui deve ser discutido é do caráter da lírica enquanto estruturação externa do poema e a questão das diversas vivências apontadas nos poemas e que mostram uma cisão entre passado e futuro - e ainda mais a se destacar, o papel da memória. Os conceitos de memória e de duração, discutidas e apresentadas por Henri Bergson, nos auxiliam e são a base com que refletimos sobre o papel da memória e o da arte para a manutenção dela. Bergson diz que a memória é viva, presente, total, virtual e é atualizada na vida ativa em função da ação. Mas qual seria exatamente essa ação? É a ação do estar vivo na duração, no movimento, sempre e interminavelmente. Para Bergson, temporalidade é duração. Ele afirma, especialmente em Matéria e memória, que tudo dura e que durar implica continuar se modificando; durar é mudar. O tempo para Bergson é um contínuo indivisível; logo, o tempo real é puro movimento e mudança (BERGSON, 2011). Entendemos que a poética cesárea é a de uma arte da vida, da experimentação da vida em suas dimensões principalmente temporais e sensíveis, e, por isso, 
percebe uma realidade em transformação permanente, precária, em que não existem coisas estáticas: em tudo há dinamicidade e contínua construção e reconstrução. É o "eternamente" sendo condição para buscar e conseguir a perfeição das coisas, mas é também o eternamente como resultado do buscar e conseguir. A "perfeição das coisas" é uma nova realidade (já que esta é, em aparência, imperfeita, mas em essência, "perfeita"), em que a obra de arte se expressa como um objeto vivo, como um fluxo e principalmente, como já apontamos, como uma ontologia.

Do conceito de realidade temporal, Bergson opõe, ou desenvolve a partir de um, as noções de tempo do senso comum e do senso comum filosófico. O tempo "fillosófico" concentra-se em pensar de forma sistemática, mas apartada do sujeito, a ideia de que a duração deve ser pensada a partir de espaços, isto é, a percepção do tempo, segundo os filósofos, depende da notação espacial para se realizar. Para Bergson, esse não é o tempo "real", mas da inteligência. $O$ tempo da inteligência se afasta da realidade e a vê a partir de fórmulas e esquemas. É o tempo do cronometro. O tempo real é vivido: sua duração não mais pode ser contada a partir de formulações objetivas, mas depende exclusivamente da subjetividade de cada sujeito a ideia da duração. Assim, os dois pontos fundamentais do pensamento de Bergson nesse aspecto são: entender o tempo real como duração e a duração como puro movimento, como devir, fluxo, sempre em mudança.

Se o tempo é duração, não podemos mais pensar o presente como algo a ser congelado e retirado do fluir do tempo. Logo, se existir um presente, só podemos dizer que o presente é a própria duração, o que inviabiliza a separação entre passado, presente e futuro. Enquanto vivência, Bergson dissolve a possibilidade desse presente instante, revelando que presente e passado são de fato simultâneos. O passado coexiste com o presente, na medida em que o passado é um passando e o presente é um durando. A constituição do passado, da memória, é automática, integral e simultânea, coextensiva ao presente. Dessa forma, quando dizemos que Cesário busca congelar o instante e presentificar a experiência das sensações, estamos dizendo, com Bergson, que, por um lado, o poeta coloca-se e coloca-nos integralmente em uma experiência, concentrando-nos nela, e por outro, como a experiência é também duração, nos dá a dinâmica da efemeridade daquela experiência, pois que ela entrará no fluxo das coisas. Essa dinâmica faz com que a sensação prazerosa contenha em si a "saudade" da coisa, pois que a percebemos como fluxo. 
Concentrarmo-nos na vida, na efemeridade, e delas redescobrimos as sensações que estavam esquecidas, ainda que paradoxalmente seja um "contentamento descontente", permite que a memória, que em geral suspense o passado em uma virtualidade, possa ser novamente colocada em vida, e presentifique em outra realidade o passado. Esse movimento surge implícita ou explicitamente na obra de Cesário. Implícita, quando ele se concentra em mostrar algo belo, e o faz utilizando verbos no tempo presente ou explorando mais o uso de substantivos e adjetivos do que os próprios verbos. Com isso, a sensação está na coisa em si, e ali permanece. Cesário, como o pintor a testar cores, dimensões, tons e temáticas, faz um "exercício" de aquarela, no poema Sardenta, mas a técnica caberá em outros poemas de vultos e em outras situações em que a beleza em si e as sensações, podem ser guardadas e revividas ao mesmo tempo, anulando, por alguns segundos, durante o deleite, o efêmero:

\footnotetext{
Tu, nesse corpo completo,

O láctea virgem dourada,

Tens o linfático aspecto

Duma camélia melada.
}

Enquanto estruturas e escolhas estilísticas que formatizam e materializam a percepção da efemeridade e a tentativa de sua suspensão ou da manutenção da sensação dela derivada, sempre nos chamou a atenção, e também não passou despercebido por outros melhores leitores, três aspectos: a variação estilística, "permitindo" classificar os poemas em escolas literárias diferentes, a intertextualidade com outras artes e, por fim, dentro de uma grande variedade de formas poéticas, o uso recorrente(já apontado anteriormente) de alguns metros específicos: o decassílabo e o alexandrino. Do primeiro caso, mostramos que as escolhas de determinadas poéticas contribuem retoricamente para a construção do sujeito na poesia, bem como instaura à nível textual, a alusão aos valores do tempo/espaço que a poética determinada aponta. Também nos parece que a profusão de escolhas, além de mostrar um conhecimento de estilística, permite a percepção de tempos e espaços distintos que, em dialética, colocam a própria arte em dinâmica. Assim, um poema de estilo Realista e outro Árcade em um quadro sinótico, nos dariam a dimensão temporal e as mudanças de representação do mundo. $\mathrm{O}$ interessante é que, a despeito dessas mudanças e de diferenças de valores, quando se utiliza uma mesma temática, se pode também falar da recorrência de determinadas coisas, em várias épocas: Cesário utiliza diversos estilos para tematizar as dores do amor, por exemplo, o que nos 
permitiu dizer que, segundo a leitura possível, em qualquer tempo, a coita amorosa aconteceria principalmente porque o homem mantém a mesma obsessão: tomar para si uma mulher ideal, mas de alguma forma proibida a ele. Mudam-se os tempos, mas algumas coisas continuam sem mudar.

Essa variabilidade ressalta ainda mais os elementos invariáveis: a técnica de recortar a cena, concentrando o olhar, para depois distende-lo, as oposições dicotômicas que vão sugerindo sínteses diversas, a manutenção da isometria nos poemas e o esforço em transformar elementos inusitados em beleza. Tal qual o sujeito muda de roupa e "veste outros séculos e valores", apontando ainda para uma impossibilidade de se definir pelo vestuário, já que nele está a própria mudança, a própria efemeridade, as trocas de estilos nos parecem uma interessante solução artística para a construção do efeito da mudança e da fugacidade, e concordam com sua mundividência. Mantém-se, entretanto, na troca, o sujeito que veste e despe: este sujeito mostra-se permanentemente preocupado em conseguir a arquitetura "clássica" ou classicista em seus versos metrificados e de rimas com acentos diversos, mas nunca brancos ou livres. O amante dos ângulos retos busca a beleza derivada dessa construção, além da constância. Para alguém que vê mudanças em tudo, a constância parece em si uma beleza e um bem. Essa breve constância presente na construção poética, além das temáticas, nos diz, de maneira implícita, que a beleza pode ser buscada e conseguida a partir também da técnica e do esforço humano. Por conseguinte, a dicotomia entre esses elementos da estrutura poética e estilísticas, remetem novamente a percepção e sensação de dinâmica, de impossibilidade de últimas definições e da própria efemeridade das coisas e dos valores.

Em outro nível de perspectiva, aquela que olha a obra como um todo, é possível perceber, concordando com Silva Pinto e Carlos Felipe Moisés, fases distintas na obra do poeta, que poderiam ser classificadas por oposição pura (como faz Silva Pinto), ou ainda mais "fragmentado", em torno de períodos de tempo que constituem alguns blocos com semelhanças estilísticas e temáticas, como aponta Moisés. A nós, parece-nos que independentemente de como se queira organizar a obra, salta aos olhos uma poética/mundividência que se constrói e constrói a sua identidade a partir da ideia da mudança. No entanto, não é tão perceptível uma "filosofia" da mudança em alguns poemas, como o da juventude, o que também se justifica exatamente porque a juventude é o apogeu de tudo: das chances, das potencialidades, do vigor físico e da ideia de beleza feminina. Mas já estava em germe a percepção da beleza como algo que, em si, poderia ser danoso. A beleza das coisas vai dando mais espaço, pouco a pouco, a 
beleza das ações. A beleza das ações, em alguns casos, poderia ser representada nas coisas: aqui, a perfeição se revelaria. $\mathrm{O}$ ato de colher a maçã ou o ato de ajudar alguém na rua a levantar um cesto poderia ser traduzido em imagens que representariam e permitiriam a (re) experimentação de tais sensações. Para além da fruição em torno do belo "fácil", isto é, aquele é aparente nas coisas, o sujeito vai percebendo outras sensações e outras belezas, e formas de captá-las e traduzi-las em letras. Por isso, também vai se valendo do diálogo com outras artes e aquilo que é próprio da matéria artística delas: no caso de Cesário, a pintura está permanentemente sendo requisitada para a construção dos poemas.

Sendo, de fato, a vontade da captura de sensações um dos motivadores desse sujeito, a pintura aproxima de forma mais direta a sensação do espectador, já que está mais próxima da coisa-mesma, do que os signos escritos, que necessitam não somente da codificação, como, em si, nada representam, mas significam. Para alguém que quer a captura da sensação das coisas, há um problema em conseguir, com esse material, o mesmo efeito. Daí que a metonímia, por exigir do leitor que vá, juntamente com o texto, compondo o todo, é um recurso abundantemente utilizado. A metonímia provoca a imaginação, já que, ao se apresentar como a concentração de um todo ou sua parte mais significativa, exige a elaboração da imagem, a distensão da concentração. Dessa forma, a imagem formada despertaria a sensação da coisa. Pensando assim, a metáfora, por exigir um exercício mais intelectual (de estabelecer os valores de A e B e suas relações, etc) do que imagético, não é tão utilizada. Também deve-se considerar que por ser um artista do "real", que lemos como observador atento do mundo físico, a descrição é amplamente utilizada, cumprindo, em partes, o papel da pintura. A visualidade e a plasticidade presentes em toda a obra nos mostram outra invariabilidade. No entanto, as poéticas das artes plásticas utilizadas são também, como as poéticas da literatura, variadas. Consegue-se com isso, o mesmo efeito já discutido com a estrutura do poema.

Tanta preocupação na manutenção de algo tão fugaz, como a beleza, quer seja ela das coisas, das ações ou um amálgama, traduz o sentimento das diversas perdas enfrentadas pelo poeta: desde as perdas amorosas, até as mais substanciais, como da irmã e do irmão. Além disso, vive ele em um momento da História particularmente conturbado e em um espaço em que isso se mostra nos diversos surtos de doenças que causaram muitas mortes, além do próprio rompimento de valores, causado pelas revoluções, tanto as tecnológicas, quanto as sociais e por fim, dos costumes. Tudo isso transparece na obra, de forma explícita. Ler a obra de Cesário é percorrer o fim do século XIX, ainda que em um país periférico às grandes inovações, e por 
isso mesmo, com marcas e lembranças do passado, sem ainda trazer a recompensa prometida pelo "futuro". Um bom exemplo é o gás que ilumina as ruas de Lisboa e de outras cidades maiores portuguesas: Joel Serrão discute como a luz artificial modifica a noção de tempo "real", vivido, ao mesmo tempo que o cheiro da queima traz outros problemas. O homem desse tempo está vendo os séculos acelerando a velocidade e se contraindo em sua própria frente. Some-se a isso a experiência pessoal da morte e perda, e podemos compreender porque a necessidade de conseguir a manutenção de certas experiências e sensações. A efemeridade aí não é um conceito, mas uma vivência. É isso que o poeta quer guardar e fazer o leitor também experimentar.

Mencionamos aqui e ali a leitura e o leitor, mas entendemos que o primeiro deles, era o próprio poeta. A partir disso, entendemos que a poesia de Cesário constrói pequenos "retratos íntimos", que, tal qual a fotografia, é além de um objeto memorialístico, também uma declaração do olhar de quem fez o retrato. Fotografar a esposa, é uma declaração de amor do marido. Fotografar uma porta bonita, é uma declaração de vontade estética do fotógrafo etc. A irmã em Nós, a descrição do pai, o irmão, os trabalhadores, os jovens no piquenique, e toda a sensação que deles a memória e a vivência emanam, mantém-se, por alguns momentos (o da leitura) naquele limbo onde a lei do tempo não mais age. Daí que há tanto "comentário", “impressões", "subjetividade" na poética do autor "realista": a ele não interessa somente a experimentação da coisa, mas a experimentação e o que ele sentiu naquela ocasião. O que ele quer com os retratos não é somente a manutenção do mundo objetivo e suas sensações, mas também a sensação dele próprio, durante o ato. Parece-nos que os retratos funcionam, nesta lógica, dentro da poesia, como um resgate de si mesmo, além do que está em ausência. Esse resgate, na nossa leitura e como consequência lógica do que estamos discutindo, é de um sentimento preponderante na obra: o amor. Quando a arte não pode resgatar isso, perde a sua serventia e o seu valor. E sobre o amor que discutimos na última seção:

E agora, de tal modo a minha vida é dura,

Tenho momentos maus, tão tristes, tão perversos,

Que sinto só desdém pela literatura,

E até desprezo e esqueço os meus amados versos! 


\section{Os amores de Cesário Verde}

Anteriormente, discutimos a questão do Eros em torno principalmente de um amornecessidade, presente naqueles poemas em que há um sujeito enamorado por uma beleza estonteante e nessa beleza, ele pretende se realizar. Nesta seção, iremos ampliar a noção de amor, ou dar continuidade, já que começamos a discutir a ideia de que há uma beleza na ação de onde deriva um outro tipo de sentimento, além do que se satisfaz com a beleza-em-si: o amor. Há uma necessidade de se definir sobre quais conceitos iremos refletir tal sentimento para podermos compreender a fundamentação da obra de Cesário. Para isso, utilizamos os conceitos presentes em C. S. Lewis (2005), no livro "Os quatro amores". Uma vez que tenhamos estabelecido tais conceitos, passaremos, a partir deles, perceber o amor como leitmotiv verdiano, e presente especificamente em Nós e Provincianas.

O primeiro amor é a afeição fraternal ou storge. Este amor fala do afeto com a família, especialmente entre os membros da família ou pessoas que se encontraram de outra maneira por acaso. As características deste tipo de amor é que seria como o mais natural, o mais emotivo, e difundido. Natural, pois não existiria qualquer coerção para que houvesse tais laços; emotivo porque é o resultado do afeto devido à familiaridade; e difundido o mais extensamente pode transcender a maioria de fatores discriminadores para o gostar. Quando duas pessoas descobrem uma a outra e comunicam uma a outra a sua visão, nasce a amizade. E imediatamente elas se unem, em imensa solidão (LEWIS, 2005). Em outras palavras, a tendência ao companheirismo, a visão gregária e o espírito de cooperação presentes no vínculo amistoso são contrabalanceados pelo desejo que os amigos têm de se afastarem da multidão, de partilharem da identidade que os une e os distingue dos demais. Nesse sentido, o afastar-se dos demais seria, para Lewis, colocar-se diante de Deus em uma visão e uma ação mais elevada.

O outro tipo de amor é a amizade ou philia, caracterizado por ser uma forte ligação entre pessoas que compartilham um interesse ou uma vida comum. Lewis explicitamente diz que a definição de amizade é mais estreita do que o mero companheirismo: A amizade em seu sentido real existe somente se houver algo para que a amizade esteja "embasada". Dos quatro tipos de amores, esta é considerada a menos natural e tem menos associação com impulso ou emoção. Apesar destas características, era a opinião dos antigos (do próprio Lewis, também) que ele é o mais admirável dos amores porque ele não olha ao amado (como o eros), mas ele olha em busca do "embasamento"- ou seja, o dado racional que causou o relacionamento. Nesse tipo de amor, 
o sujeito deixa de centrar-se em si e pensa naquilo que está além ou acima dele, isto é, a causa da philia. Em termos concretos, este amor é fundamental para a nossa noção de comunidade e de civilização.

Eros é o amor no sentido de "estar no amor". Isto é distinto da sexualidade, que Lewis chama de Vênus. Identifica o eros como indiferente (sexualmente dizendo) e faz com que o sujeito enamorado aprecie o amado não obstante todo o prazer que puder ser obtido dele. Desmedido, como já discutimos, leva o sujeito a perder a própria identidade ou a querer centrarse somente no ser ou objeto amado. Oposto a isso, estaria o último amor, a caridade ou agapē: este é um amor dirigido alguém que não precisa possuir quaisquer qualidades consideradas "adoráveis" (como beleza, ou virtudes, ou riquezes etc). Lewis reconhece este como o maior dos amores, porque é um amor ao outro que vai além do dever (philia), da necessidade (eros) ou da vontade (storge), estando em uma gratuidade, ou o amor do amor. Lewis compara metaforicamente o amor com um jardim, a caridade com os utensílios do jardineiro, o amante como o próprio jardineiro, e Deus como os elementos da natureza. O amor e a orientação de Deus agem em nosso amor natural (que não pode remanescer o que é por si) como o ato do sol e da chuva em um jardim: sem um ou outro, o objeto (metafórico do jardim; realisticamente o amor próprio) cessaria de ser bonito ou digno.

A partir dessas definições, temos subsídios para pensarmos, na realidade dos poemas apontados, a ideia do amor presente em Cesário. Para isso, faremos alguns recortes no poema, para posterior síntese das ideias, a partir dos amores.

\section{(...)}

Ora meu pai, depois das nossas vidas salvas

(Até então nós só tivéramos sarampo),

Tanto nos viu crescer entre uns montões das malvas

Que ele ganhou por isso um grande amor ao campo!

Se acaso o conta, ainda a fronte se lhe enruga:

O que se ouvia sempre era o dobrar dos sinos;

Mesmo no nosso prédio, os outros inquilinos

Morreram todos. Nós salvamo-nos na fuga. 


\section{(...)}

Por isso, o chefe antigo e bom da nossa casa,

Triste de ouvir falar em órfãos e em viúvas,

E em permanência olhando um horizonte em brasa,

Não quis voltar senão depois das grandes chuvas.

Ele, dum lado, via os filhos achacados,

Um lívido flagelo e uma moléstia horrenda!

E via, do outro lado, eiras, lezírias, prados,

E um salutar refúgio e um lucro na vivenda!

E o campo, desde então, segundo o que me lembro,

É todo o meu amor de todos estes anos!

Nós vamos para lá; somos provincianos,

Desde o calor de maio aos frios de novembro!

Os trechos anteriores, presentes na parte I do poema Nós, apresentam a figura do pai, o amor que sente pelos filhos e o amor que o sujeito sente pelo pai e pelo campo. Percebemos no pai, além do natural amor fraternal, um amor de philia pelo campo: lá, ele vê saúde e lucro. Mas essa a forma que o filho, o eu-lírico do poema, vê o campo? Ou nele encontrará um outro tipo de amor, que justificará ser o campo "todo o meu amor de todos estes anos!". Note-se que o uso de todo e todos concede a ideia de plenitude. É assim que vê o campo. Como uma plenitude em termos de modo e de tempo. Nos parece que ultrapassa o amor sentido pelo pai, mas é no poema que teremos tais confirmações e razões.

Que de fruta! E que fresca e temporã,

Nas duas boas quintas bem muradas,

Em que o Sol, nos talhões e nas latadas,

Bate de chapa, logo de manhã!

$$
\text { (...) }
$$

Que de frugalidades nós criamos!

Que torrão espontâneo que nós somos!

Pela outonal maturação dos pomos, 
Com a carga, no chão pousam os ramos.

E assim postas, nos barros e areais, As macieiras vergadas fortemente,

Parecem, duma fauna surpreendente

Os pólipos enormes, diluviais.

Contudo, nós não temos na fazenda

Nem uma planta só de mero ornato!

Cada pé mostra-se útil, é sensato,

Por mais aromas que recenda!

Finalmente, na fértil depressão, Nada se vê que a nossa mão não regre:

A florescência dum matiz alegre

Mostra um sinal - a frutificação!

As estrofes anteriores estão carregadas dessa admiração pelo campo e não somente pela sua beleza, mas principalmente por sua utilidade: a beleza da macieira carregada está que ela mostra a fertilidade e o resultado do trabalho. A philia transparece pelo uso da razão, em detrimento da emoção (presente). Grande parte do poema é a construção e a apresentação de um campo, secreto aos homens que nele não vivem ou não trabalham. Esse campo, dicotomicamente, é apresentado como belo e útil, mas também como trabalhoso e de difícil lida. É esse aspecto que proporciona uma outra leitura: ainda que desagradável e ainda que coloque vários obstáculos sobre o trabalho do campo e seu "rendimento", devemos nos lembrar que no presente do poema, que se encontra na introdução, nas partes que medita os acontecimentos com a irmã e ao final, o amor ao campo permanece. Não somente ao campo, mas às pessoas que nele trabalham e enfrentam uma vida difícil, mas não deixam de buscar e aprimorar as plantações, as ferramentas, etc. Não há beleza nesses trechos, mas a constatação do esforço humano contra a Natureza.

Mas hoje a rústica lavoura, quer

Seja o patrão, quer seja o jornaleiro,

Que inferno! Em vão o lavrador rasteiro

E a filharada lidam, e a mulher! 
Desde o princípio ao fim é uma maçada

De mil demônios! Torna-se preciso

Ter-se muito vigor, muito juízo

Para trazer a vida equilibrada!

Hoje eu sei quanto custam a criar As cepas, desde que eu as podo e empo.

Ah! O campo não é um passatempo

Com bucolismos, rouxinóis, luar.

A nós tudo nos rouba e nos dizima:

$\mathrm{O}$ rapazio, o imposto, as pardaladas,

As osgas peçonhentas, achatadas,

$\mathrm{E}$ as abelhas que engordam na vindima.

O que acontece entre a visão idílica do campo para este campo concreto? Entre uma visão e outra, há a morte da irmã. Ela é o centro do poema, mais do que as longas descrições do trabalho campestre. Nós fala, utilizando este pronome pessoal, do amor em família, do amor útil e da ausência de um amor caridoso, pois que há, na obra e na mundividência de Cesário, a ausência da transcendência. Entretanto, se neste poema está ausente o amor ágape, consideramos que em Num Bairro Moderno e também em Nevroses, ainda que não esteja preocupado com a transcendência, o amor caridoso se manifesta materialmente da forma mais simples: pelo amar um outro, sem necessidade, sem vontade e sem que o outro lhe seja útil de qualquer forma. Ainda que seja este amor uma aproximação de um sujeito e Deus, a não declaração da divindade, não anula a presença dela. No entanto, a morte da irmã retira o sujeito do estado de encantamento e de amor e o coloca em outra situação: naquela em que ele pretende manter viva a memória, as sensações e o sentimento de amor que nutre pela irmã. Se o sujeito a amava enquanto amor fraternal, após a sua morte, qual seria o tipo de amor? Sabemos que é pela arte que pretenderá manter viva a memória da irmã.

Fecho os olhos cansados, e descrevo

Das telas da memória retocadas,

Biscates, hortas, batatais, latadas,

No país montanhoso, com relevo! 
Ah! que aspectos benignos e rurais

Nesta localidade tudo tinha,

Ao ires, com o banco de palhinha,

Para a sombra que faz nos parreirais!

Ah! Quando a calma, à sesta, nem consente

Que uma folha se mova ou se desmanche,

$\mathrm{Tu}$, refeita e feliz com o teu lunch,

Nos ajudavas, voluntariamente!...

$$
\text { (...) }
$$

Douradas, pequeninas, as abelhas,

E negros, volumosos, os besouros,

Circundavam, com ímpetos de touros,

As tuas candidíssimas orelhas.

Que de encantos! Na força do calor

Desabrochavas no padrão da bata,

E, surgindo da gola e da gravata,

Teu pescoço era o caule duma flor!

Mas que cegueira a minha! Do teu porte

A fina curva, a indefinida linha,

Com bondades de herbívora mansinha,

Eram prenúncios de fraqueza e morte!

À procura da libra e do shilling,

Eu andava abstrato e sem que visse

Que o teu alvor romântico de miss

Te obrigava a morrer antes de mim!

E antes tu, ser lindíssimo, nas faces

Tivesses "pano" como as camponesas: 
E sem brancuras, sem delicadezas,

Vigorosa e plebéia, inda durasses!

$(\ldots)$

O Nós particular da família, no trecho anterior, contrapõe-se a um "eles", presente no povo, nos plebeus. Nesses, há um vigor e uma saúde - um destino mais ameno em relação aos que morrem cedo, os Nós, por falta de uma constituição física e biológica adequada para este mundo "doente". Essa admiração ao povo transparece em toda a obra de Cesário, que os apresenta sempre com alguma notação artística ou deles buscando alguma beleza. Pode ser por esse vigor e saúde, e também por serem "úteis", tal qual ele muitas vezes busca ser, mas pode ser também por um amor "desinteressado", que admira o outro sem que ele lhe seja particularmente próximo, lhe seja especialmente útil ou lhe cause alguma admiração imediata. $\mathrm{O}$ amor ágape ao povo, ao humilde, fica ainda mais ressaltado lembrando o eros dominante na admiração às mulheres citadinas. Nós representa a cidade e a modernidade. No poema, a morte. Eles, o campo e a tradição. No poema, a vida.

Consequentemente, apesar de a caridade cristã parecer fria para as pessoas cujas cabeças estão cheias de sentimentalismo, e apesar de ser bem diferente da afeição, ela nos conduz a este sentimento. A diferença entre um cristão e um ímpio não é que este tem afeições e gostos pessoais ao passo que o cristão só tem a caridade. O ímpio trata bem certas pessoas porque gosta delas; o cristão, tentando tratar a todos com bondade, tende a gostar de um número cada vez maior de pessoas no decorrer do tempo inclusive de pessoas de quem ele não poderia imaginar que um dia fosse gostar (LEWIS, 2005, p. 175).

A impressão doutros tempos, sempre viva,

Dá estremeções no meu passado morto,

E inda viajo, muita vez, absorto,

Pelas várzeas da minha retentiva.

Então recordo a paz familiar,

Todo um painel pacífico de enganos!

E a distância fatal duns poucos anos

E uma lente convexa, de aumentar. 
Todos os tipos mortos ressuscito!

Perpetuam-se assim alguns minutos!

E eu exagero os casos diminutos

Dentro dum véu de lágrimas bendito.

Pinto quadros por letras, por sinais,

Tão luminosos como os do Levante,

Nas horas em que a calma é mais queimante,

Na quadra em que o Verão aperta mais.

Como destacam, vivas, certas cores,

$\mathrm{Na}$ vida externa cheia de alegrias!

Horas, vozes, locais, fisionomias,

As ferramentas, os trabalhadores!

A arte aparece explicitamente como instrumento para reviver e preservar a memória da irmã, mas também de todo um universo complexo representado no poema. É assim, explicitamente, um gesto amoroso, para além de um gesto estético. Nesta ação amorosa, a arte mantém viva a experiência, ainda que a experiência e as sensações, por si, não bastem ao sujeito. $\mathrm{Na}$ ausência da transcendência e da religião, o que ele tem é a imagem própria da irmã, que substitui todo o sistema religioso e toda representação religiosa, por uma beleza pueril e afetiva. Paradoxalmente, como já apontamos, a experiência estética não é uma experiência total, mas de atualização da virtualidade posta pela memória em suspenso. Para ser uma experiência total, o signo deve remeter a coisa e a coisa deve estar presente, como ser. É essa a diferença entre a literatura e a religião. A literatura é imitação ou verossimilhança. Em si, os signos somente apontam para algo. No entanto, se não há a transcendência religiosa nesse algo, estamos vendo somente um simulacro da realidade. Poeta que vê a beleza no mundo físico e ações como consequências concretas de valores, a experiência sensível do mundo, e que a arte poderia aprisionar, vai mostrar-se como ele próprio percebe, insuficiente.

\section{(...)}

Eu que de vezes tenho o desprazer

De refletir no túmulo! E medito

No eterno Incognoscível infinito,

Que as idéias não podem abranger! 
Como em paul em que nem cresça a junca

Sei de almas estagnadas! Nós absortos,

Temos ainda o culto pelos Mortos,

Esses ausentes que não voltam nunca!

Nós ignoramos, sem religião,

Ao rasgarmos caminho, a fé perdida,

Se te vemos ao fim desta avenida

Ou essa horrível aniquilação!...

E ó minha mártir, minha virgem, minha Infeliz e celeste criatura,

$\mathrm{Tu}$ lembras-nos de longe a paz futura,

No teu jazigo, como uma santinha!

E enquanto a mim, és tu que substituis

Todo o mistério, toda a santidade,

Quando em busca do reino da verdade

Eu ergo o meu olhar nos céus azuis!

III

Tínhamos nós voltado à capital maldita,

$\mathrm{Eu}$ vinha de polir isto tranqüilamente,

Quando nos sucedeu uma cruel desdita,

Pois um de nós caiu, de súbito, doente.

Uma tuberculose abria-lhe cavernas!

Dá-me rebate ainda o seu tossir profundo!

E eu sempre lembrarei, triste, as palavras ternas,

Com que se despediu de todos e do mundo!

Pobre rapaz robusto e cheio de futuro!

Mas sei dum infortúnio imenso como o seu!

Viu o seu fim chegar como um medonho muro, 
E, sem querer, aflito e atônito, morreu!...

De tal maneira que hoje, eu desgostoso e azedo

Com tanta crueldade e tantas injustiças,

Se ainda trabalho é como os presos no degredo,

Com planos de vingança e idéias insubmissas.

E agora, de tal modo a minha vida é dura,

Tenho momentos maus, tão tristes, tão perversos,

Que sinto só desdém pela literatura,

E até desprezo e esqueço os meus amados versos!

À vista do que pensamos, o papel da arte, além de preservar as sensações efêmeras, é também permitir a reexperiência dos diversos tipos de amores. Não é uma arte particularmente combativa, apesar de ter seus momentos de crítica, ou arte especialmente reflexiva e teórica. Comparando com um Antero de Quental, seu conterrâneo e contemporâneo, é de se estanhar tanta poesia sobre experiências íntimas amorosas, entrecortadas de poesias sobre verdureiras, sobre bois e sobre enxadas. Mas é o amor, e o amor também pela arte como coisa que permite tal experimentação e a preservação da sensação, que movimenta a caneta verdiana e que faz com que imprima com sua tinta saudosa e amorosa, suas letras para preservar a experiência do amor, e vencer a efemeridade das coisas e da vida. 


\section{CONCLUSÃO}

\section{O poeta amoroso}

No início deste trabalho, tínhamos claro alguns aspectos que, de fato, se materializaram neste texto: a questão do efêmero e ser a arte uma forma de manter a vivência das coisas. O que não tínhamos percebido, e fomos perceber muito depois e mais e mais durante a confecção da tese, é o aspecto amoroso presente em Cesário. Que a temática do amor existia, não havia qualquer dúvida. $\mathrm{O}$ que não tínhamos percebido, e nos esforçamos por revelar nestas tantas linhas, é que o amor era princípio e fim da arte verdiana. Princípio, pois partia das várias situações amorosas a motivação para a preservação, mesmo quando o amor mostrava-se um "perigo" ao sujeito ou não se mostrava de forma explícita, e finalidade, já que tecer a obra era, em si, um gesto de amor àquilo que pretendia "eternizar". Enquanto ontologia, isto é, objeto novo e existente no mundo, dependendo da chave adotada para a leitura, isto é, do leitor, a obra é também um gesto de amor aos leitores, conhecidos ou não. Um amor generoso, pois que inútil e que em nada acrescentou para a vida pessoal do poeta, do ponto de vista prático, além de dissabores.

Neste aspecto do amor generoso, o poema inacabado, Provincianas, representa a generosidade em seu ápice. Lá, não há presença do eu de forma explícita: é como se o artista deixasse que a coisa-em-si, tal qual um dramaturgo, suplantasse a voz lírica e, por consequência, o sujeito. Chamou-nos a atenção tal ausência declarada, diluída em um único pronome pessoal na primeira pessoa no plural, no caso obliquo. Para um poeta em que o eu domina grande parte da obra e é centro das experiências e do mundo, parecia algo a ser observado com mais atenção, com os devidos cuidados de ser obra não publicada em vida, e incompleta. Quem garante que algum crítico de renome consiga "provar" ser poesia alheia e não de Cesário ou que apareça em algum sótão as "obras completas" que a complete com alguma ironia ou que desminta o que foi proposto nas primeiras estrofes? Mesmo tendo isso em mente, ainda assim nos parece que Provincianas seria um desdobramento organicamente coerente com a obra do poeta, levando aos extremos, a arte vivencial, e a arte que cria uma sensação de amor generoso.

Aos extremos também estaria a presença do amor neste poema, sem ser mencionado, simplesmente pelas ações e pela maneira de construir e pintar um quadro tão elevado, de acontecimentos são humildes. E é humilde e amorosa a fala do sujeito que abre o poema: de 
estilo coloquial, completamente aberto ao outro, o eu inicia com um cumprimento simples, mas que é também uma valoração dos dias:

Olá! Bons dias! Em março

Que mocetona e que jovem

a terra! Que amor esparso

Corre os trigos que se movem

As vagas dum verde garço!

Como amanhece! Que meigas

As horas antes de almoço!

Fartam-se as vacas nas veigas

E um pasto orvalhado e moço

Produz as novas manteigas.

Toda a paisagem se doura;

Tímida ainda, que fresca!

Bela mulher, sim senhora,

Nesta manhã pitoresca,

Primaveral, criadora!

Além da beleza da paisagem, retoma a sua temática em que o amor ágape se mostra mais claro: os trabalhadores e sua lida diária. Por que mostrar trabalhadores da forma como se mostra? Não é elevar a teoria do trabalho ou o povo enquanto ideia, mas é retratá-los enquanto uma realidade que, em si, contém uma beleza que o seu olhar secreto revelou e revela nesta poesia. A beleza ali presente é da vida, da pujança do homem que vence a natureza, mas também nela sabe encontrar um abrigo. É o coletivo em detrimento do individual embelezando o mundo, por fazê-lo um lugar melhor e mais ameno. É, mesmo que ele não percebesse ou não quisesse perceber ou explicitar, o homem cumprindo uma missão colocada no Genesis: cuidar da terra. É, ainda, repercutindo o discurso de sua época, o homem comum herói de seu povo. Um discurso não anula o outro, complementando-se e ampliando os campos significativos.

Se este poema "finaliza" uma jornada humana e poética ou não, ele, ao menos, volta a colocar luzes em inúmeras soluções poéticas e reflexões filosóficas em torno da vida, dos amores, da arte, do que é ser sujeito nessas condições: para uma poética pouco dada a reflexões 
apartadas da realidade ou que não possam ser percebidas, há de se considerar como o caso pode suplantar o universal, exatamente porque ele se faz objetivo, específico e material. Não que não haja a arte da reflexão: um Fernando Pessoa está aí para nos desmentir. Entretanto, sem o gênio pessoano, a arte do homem comum é motivada pela vida também "comum", mas que o olhar artístico pode ver e realizar o cotidiano e o corriqueiro em uma outra instância e descobrir outros valores. Esse nos parece um dos méritos da poesia de Cesário.

O elemento efêmero, que víamos em abundância permeando e construindo toda a obra, mostrou-se, como dissemos, o efeito desse ato amoroso que posteriormente também percebemos na centralidade dessa leitura:

É nesta quadra de amores

Que emigram os jornaleiros

Ganhões e trabalhadores!

Passam clãs de forasteiros

Nas terras de lavradores.

Tal como existem mercados

Ou feiras, semanalmente,

Para comprarmos os gados,

Assim há praças de gente

Pelos domingos calados!

Enquanto a ovelha arredonda,

Vão tribos de sete filhos,

Por várzeas que fazem onda,

Para as derregas dos milhos

E molhadelas da monda.

Toda leitura, a partir da teoria pareysoniana, é também uma espécie de generosidade do leitor, isto é, que deve abrir-se para a obra, sem impor-lhe uma verdade a priori ou configurála para fazer falar a ideologia do leitor e não a mundividência formatizada na obra. Esse exercício de hermenêutica se revelou tão profícuo, que da proposta inicial ao seu fim, inúmeras modificações foram acontecendo. À medida em que se lia um poema, ele alterava alguma ideia 
já discutida anteriormente e exigia revisões, reescritas e mesmo apagamentos. Nada mais aborrece um intérprete do que ter sua "ideia inicial, genial" desmentida pela evidência da obra. No entanto, tantas foram as vezes que, paradoxalmente, a obra ia ficando cada vez mais simpática e cada vez mais se abria a leitura: estava, em alguns momentos, instaurada a congenialidade.

Sendo assim, a maior mudança deu-se efetivamente na conclusão: a ideia do amor sequer aparecia anteriormente. Lembrando das lições pareysonianas, mudou no percurso também o leitor, o que faria com que a obra também se abrisse em outra chave ou se revelasse de outra forma. Pensar que este trabalho termina falando sobre amor, ao invés de pura estilística ou de crítica a algum elemento sócio histórico pode não garantir, e não garante, a qualidade ou a correção das várias ideias propostas, mas deixa certa satisfação no autor desta leitura, porque, ao fim e ao cabo, ao fechar o livro e ao colocar o ponto final aqui, ainda assim se olhará os homens comuns, no trabalho, e se terá por eles uma espécie de amor, que a arte de Cesário Verde ressaltou, guardou e conseguiu transmitir. Somente por isso, já teria válido a pena.

De roda pulam borregos;

Enchem então as cardosas

As moças desses labregos

Com altas botas barrosas

De se atirarem aos regos!

Ei-las que vêm às manadas

Com caras de sofrimento,

Nas grandes marchas forçadas!

Vêm ao trabalho, ao sustento,

Com foices, sachos, enxadas! 


\section{BIBLIOGRAFIA}

\section{De Cesário Verde}

VERDE, Cesário. O Livro de Cesário Verde. Org. Silva Pinto. Porto Alegre: LP\&M, 2003.

VERDE, Cesário. O Livro de Cesário Verde. Org. Luís de Montalvor. Lisboa: Ática, 1992.

VERDE, Cesário. Obra Completa de Cesário Verde. Org. Joel Serrão. 4. ed. Lisboa: Livros Horizonte, 1983.

VERDE, Cesário. Poesia completa e cartas escolhidas. Org. Carlos Felipe Moisés. São Paulo: Cultrix, 1982.

\section{Antologia}

MENDES, Margarida Vieira. (org.). Poesias de Cesário Verde. 3. ed. Lisboa: Editorial Comunicação, 1987.

\section{Sobre Cesário Verde}

AMARAL, Henrique Do - A captação do real em Cesário e em Baudelaire, in Vértice, vol. XV, no. 147, Coimbra, Dez. de 1955, pp. 727-732.

AMBRÓSIO, António - Cesário Verde perante a Igreja, in Diário de Notícias, Lisboa, 21 de Dezembro de 1986.

BOM, Laurinda ; AREIAS Laura - Cesário Verde. Uma Proposta de Trabalho [ed.escolar], Lisboa, Livros Horizonte, 1983.

BUESCU, Helena Carvalhão - Dois poetas da evocação: Cesário Verde e António Nobre "Pinceladas a propósito de Cesário Verde, In Colóquio/Letras, respectivamente no. 75 Set. 1983, e no. 93, Set. 1983. . "Pinceladas. A propósito de Cesário Verde" In: Revista Colóquio/Letras. Ensaio, n. ${ }^{\text {o } 93}$, Set. 1986, p. 69-73.

CABRAL, Avelino Soares. Cesário Verde - Propostas de análise, Lisboa, Edições Sebenta, 2005. 
CEIA, Carlos. A scientia sexualis de Cesário Verde. 1995. Lisboa: Faculdade de Ciências Sociais e Humanas, Universidade Nova de Lisboa., Vol.2;N.8, 1995.

CARTER, Janet Elizabeth. Cadências tristes: o universo humano na obra poética de Cesário Verde. Lisboa: Imprensa Nacional / Casa da Moeda, 1989.

CASTRO, Silvio. O percurso sentimental de Cesário Verde. Análise semântica da obra poética. Lisboa: Instituto de Cultura e Língua Portuguesa, 1990.

CHAVES, Thaís Maria Vinci Mendonça. O estilo irônico na obra de Cesário Verde. Campinas: Programa de Pós-Graduação em Letras - Teoria Literária. IEL/UNICAMP, 1993.

COELHO, Jacinto do Prado. Cesário Verde: poeta do espaço e da memória. In: Ao contrário de Penélope. Lisboa: Bertrand, 1976. p. 195-198.

. A letra e o leitor. $2^{\circ}$ Edição. Lisboa: Moraes Editores, 1977 Problemática da História Literária. $2^{\circ}$ Edição.Lisboa: Edições

Atica, 1961.

CHANDLER, Pierrete e Gérard. Haverá um erotismo de humilhação em Cesário Verde? Letras \& Letras, Porto, v. 3, n. 34, p. 7-8, out. 1990.

DAUT, Ricardo - O Livro de Cesário Verde: Leituras e comparações, Tese de doutoramento, 1999.

DAUNT NETO, Ricardo Gumbleton. Cesário Verde: um trapeiro nos caminhos do mundo. 1991. Tese (Doutorado em Literatura Portuguesa) - Faculdade de Filosofia, Letras e Ciências Humanas da USP, São Paulo.

DÁVILA, Nícia Ribas. A SEMIÓTICA EM CESÁRIO VERDE. DE TARDE, UM POEMA, UMA AQUARELA. In: http://niciadavila.com.br/wordpress/wpcontent/uploads/2016/07/ASemioticaemCesarioVerdeDeTardeumPoemaumaAquarela.doc FIGUEIREDO, João Pinto de. Cesário Verde. Pref. e Sel. de poemas de David Mourão-Ferreira. 2. ed. Lisboa: Presença, 1986.

A Vida de Cesário Verde. Lisboa, 2ed. Editorial Presença, 1896.

FERREIRA, Vergílio. Relendo Cesário. Colóquio Letras. Lisboa: Fundação Calouste Gulbenkian, n. 31, p.49-58, maio/1976.

GOMES, Álvaro Cardoso. O Jóquei da tartaruga. In: O poético, magia e iluminação. São Paulo: Perspectiva, 1989.

A consciência em crise em Cesário Verde. In: São Paulo: Língua e Literatura, no. 5, 1976. 
LIND, Georg Rudolf. "O real e análise" - o mundo poético de Cesário Verde. Colóquio Letras: Homenagem a Cesário Verde. Lisboa; Fundação Calouste Gulbenkian, n. 93, p.29-40, 1986.

LOPES, Óscar. Cesário Verde ou do romantismo ao modernismo. In: História ilustrada das grandes literaturas. Lisboa: Estúdios Cor, 1973.

LOPES, Rita Sousa. Para uma leitura de Cesário Verde. $1^{\circ}$ Edição. Lisboa: Editorial Presença, 2000 .

LOURENÇO, Eduardo. Os dois Cesários. In Estudos portugueses - homenagem a Luciana Stegano Picchio. Lisboa : Difel, 1991.

MACEDO, Helder. Cesário Verde, o bucolista do realismo. Colóquio Letras: Homenagem a Cesário Verde. Lisboa: Fundação Calouste Gulbenkian, n. 93, 1986.

Cesário Verde, o romântico e o feroz. Lisboa: Engrenagem, 1988. . Nós, uma leitura de Cesário Verde. Lisboa: Plátano, 1975.

MARGARIDO, Alfredo. "A dicotomia branco-negro na poesia de Cesário Verde". In: Revista

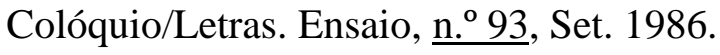

MARTINHO, Fernando J. B. Inquérito. Cesário Verde visto hoie por poetas portugueses. Colóquio Letras: Homenagem a Cesário Verde. Lisboa: Fundação Calouste Gulbenkian, n. 93, p. $108-109,1986$.

MARTINS, Albano. Inquérito. Cesário Verde visto hoje por poetas portugueses. Colóquio Letras: Homenagem a Cesário Verde. Lisboa: Fundação Calouste Gulbenkian, n. 93, p. 103, 1986.

MARTINS, Fernando Cabral. Cesário Verde ou a transformação do mundo. Lisboa: Comunicação, 1988.

MARTINS, Francisco. Em torno da recepção d'O livro de Cesário Verde. Letras \& Letras. Porto, v.3, n. 34, p. 11, out. 1990.

MINÉ, Elza. Da transformação fantasiosa à explosão onírica: Arcimboldo, Cesário e Aníbal Machado. Letras \& Letras. Porto, v. 3, n. 34, p. 9-10, out. 1990.

MOISÉS, Carlos Felipe. O Desconcerto do Mundo: do Renascimento ao Surrealismo. São Paulo: Escrituras Editora, 2001 - (Coleção ensaios transversais).

MOURÃO-FERREIRA, David. Camões e Cesário: uma leitura complementar de "O Sentimento dum Ocidental”. Colóquio Letras. Lisboa: Fundação Calouste Gulbenkian, n. 133134, 1994.

Notas sobre Cesário Verde. In: Hospital das letras. Lisboa: Guimarães, 1966.

NASCIMENTO, Luciana Marino do. Entre Paris e Lisboa: a modernidade de Cesário Verde / Luciana Marino do Nascimento. - - Campinas, SP: [s.n.], 2003. 
ORTIGÃO, Ramalho. [Cesário Verde] XXVI. A musa moderna - Conselhos a um jovem poeta. IN: Farpas Escolhidas. Sel. e Introd. Ernesto Rodrigues. Lisboa: Ulisséia, s/d. Acesso: 16 Nov 2016.

PASCHOALIN, Maria Aparecida - A Poesia de Cesário Verde: Lirismo e Realidade Social, dissertação de mestrado pela USP, 1980.

PERRONE-MOISÉS, Leyla - Cesário Verde: um "astro sem atmosfera"?. Veredas. № 3 (2000) RECKERT, Stephen. Um ramalhete para Cesário. Lisboa: Assírio e Alvim, 1987.

RÉGIO, José - Sobre o realismo de Cesário, in Estrada Larga, I, Porto, 1958, pp. 329-395.

ROCHA, Andrée Crabbé - A presença do real na poesia de Cesário Verde, in Estrada Larga. _ “Cesário Verde, poeta barroco? ”, in Colóquio/Letras, no. 1, Lisboa, 1971, pp. 31-33.

Cesário Verde, poeta barroco. Colóquio Letras. Lisboa: Fundação Calouste Gulbenkian, n. 1, mar. 1971.

RODRIGUES, Fátima. Cesário Verde - Recepção e poética oitocentista. Lisboa: Cosmos, 1998.

SALGADO-JÚNIOR, António. Introdução ao estudo de Cesário. In: BARRETO, Costa (Org.). Estrada larga. Porto: Porto, v. 1, 1946.

SARAIVA, António José. A esquina do século - Cesário Verde. In: Iniciação na literatura portuguesa. 3. ed. Lisboa: Gradiva, 1997.

SENA, Jorge de. A linguagem de Cesário Verde. In: SENA, Mécia (Org.). Estudos de literatura portuguesa I. Jorge de Sena. Lisboa: Ed. 70, 1981. (Col. Obras de Jorge de Sena)

SOUZA, Carlos Mendes de. Um olhar atravessando a luz. Cadernos de Literatura. Coimbra: Instituto Nacional de Investigação Científica/Centro de Literatura Portuguesa da Universidade de Coimbra, n. 24, out. 1986.

SACRAMENTO, Mário - Lírica e Dialéctica em Cesário verde, Ensaios de Domingo, Coimbra, 1959, pp. 93-137.

SENA, Jorge - A linguagem de Cesário Verde, Estrada Larga I.

SERRÃO, Joel - Cesário Verde - Interpretação, poesias dispersas e cartas, Lisboa, 1957. Temas Oitocentistas - I: Para a história de Portugal no século passado. Lisboa: Portugália Editora,1962. Funchal,Portugal: Livros Horizonte, 1980.

Temas Oitocentistas - II: Para a história de Portugal no século passado.

Lisboa: Portugália Editora, 1962.

SIMÕES, João Gaspar - Eça de Queiroz, mestre de Cesário Verde e precursor da poesia moderna, in O Primeiro de Janeiro, Porto, 14-3-1945.

TORRES, Alexandre Pinheiro - A Paleta de Cesário Verde, Lisboa, 2003. 


\section{Geral}

ABDO, Sandra. SOBRE O PROBLEMA DA AUTONOMIA DA ARTE E SUAS IMPLICAÇÕES HERMENÊUTICAS E ONTOLÓGICAS. KRITERION: Belo Horizonte, $n^{\circ}$ 112, Dez/2005.

ARISTÓTELES, HORÁCIO, LONGINO. A Poética Clássica. Introdução: Roberto Oliveira Brandão. Trad: Jaime Bruna. São Paulo: Cultrix, 2007.

ARISTOTELES. ETHICA NICOMACHEA - I 13 - III 8 TRATADO DA VIRTUDE MORAL. São Paulo: Editora Nacional, 2008. . Retórica. Sã Paulo; Editora Nacional, 2011.

AUERBACH, Erich. Sacrae scripturae sermo humilis. In: "Ensaios de Literatura Ocidental".Trad: Samuel Titan Jr. e José Marcos Mariani de Macedo. São Paulo: Ed. 34, 2000. . Sermo humilis. In: "Ensaios de Literatura Ocidental”.Trad: Samuel Titan

Jr. e José Marcos Mariani de Macedo. São Paulo: Ed. 34, 2000.

BACHELARD, Gaston. A Poética do Espaço. $6^{\circ}$ Edição.Trad. Antonio de Pádua Danesi.São Paulo: Editora Martins Fontes,2003. Título original: La Poétique de L'Espace

BAUDELAIRE, Charles. Sobre a modernidade o pintor da vida moderna. Rio de Janeiro: Paz e Terra, 1996.

BENJAMIN, Walter. Charles Baudelaire: Um lírico no auge do capitalismo. Tradução José Carlos Martins Barbosa e Hemerson Alves Baptista. 3. ed. São Paulo: Brasiliense, 1994. (Obras escolhidas III).

Magia e técnica arte e política. Tradução Sérgio Paulo Rouanet. São Paulo: Brasiliense, 1985. (Obras Escolhidas I).

O Narrador. Tradução Modesto Carone. São Paulo: Abril, 1975. p. 63-81.(Col. Os Pensadores).

Passagens. BOLLE, Willi (org.). Tradução Cleonice Paes Barreto Mourão e Irene Aron. Belo Horizonte: UFMG; São Paulo: Imprensa Oficial do Estado de São Paulo, 2006.

Sobre alguns temas em Baudelaire. Tradução Edson Araújo Cabral e José Benedito Damião. São Paulo: Abril Cultural, 1975. (Col. Os Pensadores).

COMTE-SPONVILLE, A. (1995). Pequeno tratado das grandes virtudes. São Paulo: Martins Fontes. 
CORBIN, Alain. O segredo do indivíduo. Trad. Denise Bottmann e Bernardo Joffily. In: PERROT, Michelle(org.).História da Vida Privada 4: Da Revolução Francesa à Primeira Guerra. 10 ed.reimp.São Paulo: Companhia das Letras, 2006. Título Original: Historie de la vie privée, vol 4: De la Révolution à la Grande Guerre.

DE LA TAILLE, Y. (1994). Prefácio à edição brasileira. In: O juízo moral na criança. São Paulo: Summus Editorial, 1932 (ed. brasil. 1994) (2006). Moral e ética: dimensões intelectuais e afetivas. Porto Alegre: Artmed. DUARTE, Lélia Parreira. Ironia e humor na literatura. Minas Gerais: Ed. PUCMinas, 2006. DUBY, Georges. A Emergência do Indivíduo.Trad. Maria Lucia Machado. In: DUBY, Georges (Org.). História da Vida Privada, 2: Da Europa feudal à Renascença. 13. ed. São Paulo: Companhia das Letras, 1990.Título Original: Histoire de la vie privée, vol.2: De l'Europe féodale à la Renaissance.

DUBY, Georges (Org.). História da Vida Privada 3: Da Renascença ao Século das Luzes. 13. ed. São Paulo: Companhia das Letras, 1990.Título Original: Histoire de la vie privée, vol 3: De la Renaissance aux Lumières.

ECO, Umberto. A estrutura ausente. Introdução à pesquisa semiológica. Trad. Pérola de Carvalho.São Paulo, Perspectiva, Editora da USP, 1971 (Coleção Estudos). Titulo original: La struttura assente.

História da Feiúra. $1^{\circ}$ Edição. Trad. Eliana Aguiar. Rio de Janeiro: Editora Record, 2007. Título original: Storia della brutezza.

Interpretação e Superinterpretação. $3^{\circ}$ Edição. Trad. M.F. São Paulo:

Editora Martins Fontes, 2001. Título original: Interpretation and Overinterpretation.

FERNANDES, Annie Gisele. Espaços do ser e do não-ser e a construção do sujeito em Mário de Sá-Carneiro. In: FERNANDES, Annie Gisele; OLIVEIRA, Paulo Motta. Literatura Portuguesa: Aquém-Mar. Campinas: Editora Komedi, 2005.

FERRAZ, Maria de Lourdes. A ironia romântica (estudo de um processo comunicativo). Lisboa: Imprensa Nacional, 1987.

FOISIL, Madeleine. A Escritura do Foro Privado. Trad. Hildegard Feist. In: ARIÉS, Philippe; DUBY, Georges (Org.). História da Vida Privada 3: Da Renascença ao Século das Luzes. 13. ed. São Paulo: Companhia das Letras, 1990.Título Original: Histoire de la vie privée, vol 3: De la Renaissance aux Lumières.

GARCEZ, Maria Helena Nery. O tabuleiro antigo: uma leitura de heterônimo Ricardo Reis. São Paulo: Edusp, 1990. 
A estética de Luigi Pareyson: alguns princípios fundamentais e alguma aplicação da articulista. In: http://dlcv.fflch.usp.br/node/52. Acesso: 15 Jun 2016. HEIDEGGER, Martin. El Ser y el Tiempo. $4^{\circ}$ Edição. Trad. José Gaos. México: Editora Fondo de Cultura Económica,1971. Título original: Sein und Zeit.

IZQUIERDO, Ivan. Memórias. Estud. av., São Paulo, v. 3, n. 6, p. 89-112, Aug. 1989 . Available from $\quad<$ http://www.scielo.br/scielo.php?script=sci_arttext\&pid=S010340141989000200006\&lng=en\&nrm=iso>. access on $29 \quad$ Nov. 2016. http://dx.doi.org/10.1590/S0103-40141989000200006.

LEWIS, C. S. Cristianismo puro e simples. São Paulo; Martins Fontes, 2005. . Os quatro amores. São Paulo: Martins fontes, 2005.

LIPOVETSKY, Gilles. O império do efêmero: a moda e seu destino nas sociedades modernas. Trad. Maria Lúcia Machado. São Paulo: Companhia das Letras, 2009.

LIPOVETSKY, Gilles. SERROY, Jean. A cultura mundo: resposta a uma sociedade desorientada. Trad. Maria Lúcia Machado. São Paulo: Companhia das Letras, 2011.

MARQUES, Jose da Cruz Lopes. APROXIMAÇÕES ENTRE KIERKEGAARD E CS LEWIS EM TORNO DO CONCEITO DE AMOR" Approaches between and Kierkegaard CS Lewis around the love concept". Paralellus, v. 6, n. 13, p. 495-514, 2016.

MERLEAU-PONTY, M. Fenomenologia da Percepção. São Paulo: Marins Fontes, 1999. O visível e o invisível. São Paulo: Perspectiva, 2003

NATÁRIO, Celeste. A Situação de Portugal na Europa no final do século XIX e início do século XX: a Geração de 70. São João Del-Rey: Revista Estudos Filosóficos nº 1 /2008.

ORIONE, Eduíno José. A revisitação do amor cortês no conto "Bárbara". Revista FronteiraZ: São Paulo, n. 9, dezembro de 2012. 47

PAREYSON, Luigi. Dostoiévski: Filosofia, Romance e experiência religiosa. Trad. Maria Helena Nery Garcez, Sylvia Mendes Carneiro. São Paulo: Edusp, 2012.

Verdade e Interpretação. Trad. Maria Helena Nery Garcez, Sandra Neves Abdo. São Paulo: Martins Fontes, 2005.

PAZ, Octavio. O Desconhecido de si mesmo - Fernando Pessoa. Trad. Sebastião Uchoa Leite. In: Signos em Rotações. 3. ed. São Paulo: Editora Perspectiva, 2003.

PRAZ, Mario. A Carne, a morte e o diabo na literatura romântica. Trad. Philadelpho Menezes. Campinas: Ed. UNICAMP, 1996.

Literatura e artes visuais. Trad: José Paulo Paes. São Paulo: Cultrix, 1982.

PEREIRA, José Carlos Seabra - Decadentismo e Simbolismo na Poesia portuguesa, Coimbra, 1975. 
POLO, Leonardo. La libertad posible.

In:http://iterhominis.com/03_Polo/01_Livros/PHC/PHC_02.htm. Acesso em: 10 Jan 2017.

ROUGEMONT, Denis. História do Amor no Ocidente. Trad. Paulo Brandi ; Ethel Brandi Cachapuz. 2. ed. São Paulo: Ediouro, 2003.

SCHAPIRO, M. Impressionismo. Trad: Ana Luiza Dantas Borges. São Paulo: Cosac \& Naif, 2002.

SUASSUNA, Ariano. Iniciação à Estética. Rio de Janeiro: José Olympio, 2004. 